\title{
Race and the Core Curriculum im Legal Education
}

\author{
Frances Lee Ansley
}

\section{TABLE OF CONTENTS}

I. Legal Education and the Canon Debate $\ldots \ldots \ldots \ldots \ldots \ldots . \ldots 1513$

A. Introduction: The Thesis ..................... 1513

B. The Legal Core Curriculum $\ldots \ldots \ldots \ldots \ldots \ldots \ldots \ldots \ldots 15$

1. Its Backwardness ........................... 1515

2. Its Advantages .......................... 1519

II. Race in a Law School Classroom: Case Study........... 1521

A. Property Class and Gratuitous Transfers Class ........ 1521

1. Roots of Title in the New World .............. 1521

2. Slavery ............................... 1523

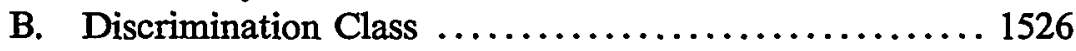

1. Background ............................ 1526

2. The First Class ......................... 1528

3. Course Structure........................... 1537

4. Race and the Constitution ................... 1539

C. The Underground Classroom ................... 1554

III. Race in the Law School Classroom and in the Legal Canon:

The Thesis Revisited ............................ 1572

A. The Classroom ........................... 1572

1. On Indoctrination ...................... 1572

2. On Doing the Right Thing .................. 1583

B. The Canon ................................ 1586

C. Conclusion $\ldots \ldots \ldots \ldots \ldots \ldots \ldots \ldots \ldots \ldots \ldots \ldots \ldots \ldots \ldots \ldots$ 


\title{
Race and the Core Curriculum in Legal Education
}

\author{
Frances Lee Ansley†
}

Controversy about the value and meaning of a canon of traditional western culture has been raging on American university campuses for some time. Professor Ansley argues that in light of the history of the Constitution, the legal academy should be in a better position than the rest of the university to achieve broad.consensus on an issue that has proved divisive elsewhere: the centrality of race to our discipline and its core texts. She elaborates by narrative, describing some of her experiences with teaching about race and sharing the reflections of her students as they encountered racially charged texts and interactions in the law school classroom. The deep racial divisions that presently exist throughout society, coupled with the discomfort and ignorance that tend to characterize our infrequent attempts to communicate about matters of racial difference, will complicate easy consensus about whether and how to more explicitly recognize race in the law school's core curriculum. She nevertheless argues that the rewards of such integration are worth the difficulties and concludes that

$\dagger$ Associate Professor of Law, University of Tennessee. A.B. 1969, Harvard-Radcliffe; J.D. 1979, University of Tennessee; LL.M. 1988, Harvard.

Relevant in my view to the issues I will be discussing in this Essay are sone additional pieces of biographical information that do not reveal thenselves from the dates and sources of my acadenic degrees. I am a white woman in my mid-forties, Southern by heritage, birth, and rearing. On one side of ny family I am a second-generation college graduate, fourth-generation on the other. For eight years after law school I was a plaintiff's personal imjury litigator in Knoxville, Tennessee. I rcturned to the legal academy to teach in 1988. For a critique of the notion that you as a reader should find any of this race-, class-, and gender-related information relevant to your reading, see Stephen L. Carter, Academic Tenure and "White Male" Standards: Some Lessons from the Patent Law, 100 YALE L.J. 2065 (1991) ("[i]t is tine to step away from labels and categories, tine to stop worrying about who is writing fron what perspective," id. at 2085).

I want to thank the many people who were kind enough to read earlier drafts of this Essay, who fed me pieces of information, or who otherwise inspired or offered help and support for the teaching efforts that I describe below. These people include Derrick Bell, Pat Cain, Joe Cook, Kim Crenshaw, Alan Freenian, Nina Gregg, Pat Hardin, Camille Hazeur, Chuck Lawrence, Howard Lesnick, Toni Pickard, Glenn Reynolds, John Sebert, Jim Sessions, Barbara Stark, Greg Stein, Mark Tushnet, Dick Wirtz, and Marilyn Yarbrough. I also am grateful for the research assistance provided both in fat tinies and lean by Kelly Bryson, Mary Copeland, Patricia Crotwell, John Goergen, Robin Miller, and Ernestine Thonias. Finally, of course, this Essay could never have cone to be without the students in my Discrimination class of fall 1989, many of whose thoughtful and lively words you will be reading below. Other students in my Race and Gender in American Law seninars, in Women and the Law, and in ny spring 1991 Discrimination class have also taught me nuch that helped inform this Essay at every stage, and I thank them too. The final product is, of course, my own responsibility. 
matters of racial justice, both past and present, are an indispensable part of minimal cultural literacy for American lawyers and legal scholars.

I

\section{Legal Education and the Canon Debate}

\section{A. Introduction: The Thesis ${ }^{1}$}

Even those of us in law schools, with our often loose and provisional relationship to the rest of the academy, cannot fail to notice the controversy now raging in the larger university about "the canon." 2 The contest is both heated and far-reaching. ${ }^{3}$

Some participants in this debate fear that the inherited wisdoms of the various disciplines are suffering erosion and disintegration due to

1. First names of authors and editors are included in footnotes throughout to provide a method, albeit imperfect, for allowing ideutification of the gender of authors and editors cited.

2. Some sense of what I mean by "the canon" will emerge in the discussion that follows. In a very geueral way, the term refers to a body of texts, perhaps of events, ideas, and nonverbal cultural creations, that are held to form a core that either is or should be presented to the next generation of learners as somehow central to, even definitive of, their heritage. The meaning of this core, whether it does or should exist at all, and if so what exactly should be included in it, are all topics of hot dispute.

3. See, e.g., Karen J. Winkler, Organization of American Historians Backs Teaching of NonWestern Culture and Diversity in Schools, Chron. Higher Educ., Feb. 6, 1991, at A5, col. 2 (examining debate over multicultural education in public schools); Scott Heller, 'Entrepreneur' of the Core Curriculum Fights the Devil on the Side, Chron. Higher Educ., Jan. 9, 1991, at A3, col. 2 (in favor of a core curriculum, Carl Raschke argues that a core curriculum is not a "canou" and that a core curriculun requires imterdisciplinary thinking); W. Robert Connor, Milton as Misogynist, Shakespeare as Elitist, Homer as Pornographer, Chron. Higher Educ., Dec. 5, 1990, at A48, col. 1 (arguing against trcating literary works as products of historical and social contexts); Further Debate on Core Curricula: a Parable on Upward Mobility, Chron. Higher Educ., Jan. 24, 1990, at A17, col. 1 (chairman of National Endowment for the Humamities beheves that there is a false dichotomy between process and content in core curriculum debate); Eugene M. Hughes, Commentary: Taking Responsibility for Cultural Diversity, BLACK Issues HIGHER Educ., Jan. 18, 1990, at 24 (favoring culturally diverse curriculum at the university level); Eileen M. O'Brien, Debate Over Curriculum Expansion Continues, Black Issues Higher Educ., Nov. 23, 1989, at 1 (discussing debate over contents of core curriculum); Scott Heller, Press for Campus Diversity Leading to More Closed Minds, Say Crities, Chron. Higher Educ., Nov. 8, 1989, at A13, col. 2 [hereinafter Heller, Press for Campus Diversity] (discussing meeting where many attendees agreed that core curriculum should focus on westem civilization); Scott Heller, Model Curriculum for Colleges Proposed by Humanities Chief, Chron. Higher Educ., Oct. 11, 1989, at A1, col. 4 (report by National Endowment for the Humanities einphasizes western texts); Scott Heller, New Attempts Planned to Define Core Curriculum, Chron. Higher Educ., Oct. 11, 1989, at A14, col. 1 (highlighting debate on merits of structured general-education sequence); Scott Heller, Colleges Told to Stress Tradition and Shared Views Even as They Bring More Diversity Into Curricula, Chron. Higher Educ., Oct. 4, 1989, at A16, col. 3 (university president urges educators to stress what is in common and not what is different); Forum: Who Needs the Great Works?, HARPER's, Sept. 1989, at 43 (colloquy on the canon and core curriculum between E. D. Hirsch Jr., Gayatri Spivak, Roger Shattuck, Jon Pareles, and John Kaliski); Elizabeth Greene, 'Teach the Conflicts, Teach the Conficts,' Preaches This Humanist, Chron. Higher Educ., Feb. 8, 1989, at A3, col. 2 (a professor urges educators to teach about the debate itself); James Atlas, On Campus: The Battle of the Books, N.Y. Times, June 5, 1988, §6 (Magazine), at 23 (discussing debate over "canon" and "books that constituted the intellectual heritage of educated Americans, that had officially been defined as great," id. at 25). 
thoughtless faddism and neglect. As a result, say these observers, today's students are culturally illiterate and display alarming gaps not only in their knowledge of our civilization and shared heritage but also in their appreciation for the great universals that unite humankind. These defenders of a traditional canon propose the definition and transnission of a core of classic works as an antidote to this deterioration of American education. ${ }^{4}$

Others perceive the inherited core celebrated by the defenders of the canon as offering a false universality, deeply flawed-even oppressive-in its largely unexamined exclusion or subordination of the feniale, the colored, the nonwestern, the powerless. These critics say that the most pressing need in curriculum development is not the retreat to and preservation of an ehitist, white, niale, parochial western core, but rather the conscious bringing in of previously suppressed or ignored histories and narratives, in the interest of greater justice for the disempowered and a more effective education for all. ${ }^{5}$

This Essay takes the position that legal education stands in a pecuhar posture relative to this debate and the cluster of issues surrounding it, a posture that puts us in some ways behind but in other ways ahead of our colleagues in other disciplines. On the one hand, law schools are behind the times in confronting the issues posed by the debate over the

4. "[We have missed] the opportunity of teaching young (and older) children the traditional materials of hiterate culture .... The inevitable effect of this fundamental educational mistake has been a gradual disintegration of cultural menory, causing a gradual decline in our ability to comnunicate." E. D. Hirsch, JR., Cultural Literacy: What Every AMERICAN NeEds To KNow 113 (1987); see also Allan BloOM, THE Closing of the AMERICAN MiNd (1987) (deploring lack of cultural hiteracy in today's students); Lynne V. Cheney, Current Fashions in Scholarship Diminish the Value of the Humanities, Chron. Higher Educ., Feb. 8, 1989, at A40, col. 1 (arguing that classical humanities education enriches civic and personal life).

5. Dorothy Helly, for example, identifies as crucial the project to

transform [the] curriculun from the preserve of elite white nales to a knowledge base that both includes and reflects the experiences of women, in all their racial, ethnic, class, and sexual variety. The reniarkable aspect of [this project] is that it has taken place against a background of restricted resources and resistant nostalgia for the "basics," the "core," and the eternal verities of the 1950 s.

Dorothy O. Helly, Recent Books on Curriculum Integration, WOMEN's STUD. Q., Sumner 1985, at 24, 24; see also Paul LAuTER, Canons and ConteXTs (1991) (college curriculum that values and focuses upon differences provides broader education for more students than does a narrowly constructed canon). Other useful sources include the following materials available from the Center for Research on Wonien at Memphis State University: Margaret L. Anderson, Denying Difference: The Continuing Basis for Exclusion in the Classroom (1987) (keynotc address delivered at the Third Annual Workshop on Women in the Curriculun); Elizabeth Higginbotham, Integrating All Women Into the Curriculum (1988); Elizabeth K. Minnich, Conceptual Errors Across the Curriculum: Towards a Transformation of the Tradition (1986) (keynote address delivered at the Second Annual Workshop on Wonen in the Curriculum); Sandra Morgen, To See Ourselves, to See Our Sisters: The Challenge of Re-Envisioning Curriculum Change (1986) (keynote address delivered at the First Annual Workshop on Women in the Curriculum). These papers were part of the Center's Research Clearinghouse and Curriculum Integration Project. 
canon. Our basic core curriculum ${ }^{6}$ stands astoundingly unchanged and unexamined compared to that of the rest of the academy. On the other hand, because of certain salient features of American legal history we should find ourselves paradoxically advanced in our ability to reach provisional agreement on a crucial inatter still deeply divisive for our nonlegal colleagues: the centrality of racial texts, ${ }^{7}$ racial issues, and racial disputes to an educated understanding of our discipline and its heritage. If the history of the Umited States Constitution and the American legal system teaches us anything, surely one of its core messages is that race has played a key role at inany critical and formative junctures of our developinent.

In the course of the following discussion I refer to selected scholarship in this area ${ }^{8}$ but also draw on my experiences over the past two years teaching courses on race and gender at a state law school in the middle South. I use these teaching experiences both to explain the rationale behind my position and to point to some difficulties and ambiguities associated with it.

\section{B. The Legal Core Curriculum}

\section{Its Backwardness}

On one level, legal education appears to have been isolated from trends in the rest of the academy in that the core curriculuin reinains unchanged in all its monumental splendor, its feet firmly planted in the

6. I mean here by "basic core curriculum" the first-year common-law courses, criminal law, and constitutional law. For one dissatisfied commentary discussing changes in that curriculum, see Roderick A. Macdonald, Curricular Development in the 1980s: A Perspective, 32 J. LEgal Educ. 569 (1982).

7. The ambiguity of this phrase is a demoustration of the socially constructed nature of race. I intend for the phrase to imclude such overlapping categories of written and oral work as texts produced by authors of color (for example, texts on the Umited States Constitution by Frederick Douglass, Thurgood Marshall, and Sojourner Truth), texts that exphicitly address racial matters (for example, Uncle Tom's Cabin (1852) by Harriet Beecher Stowe, Dred Scott v. Sandford, 60 U.S. (19 How.) 393 (1857) by Roger Taney, and The Id, the Ego, and Equal Protection: Reckoning with Unconscious Racism, 39 STAN. L. REV. 317 (1987) by Charles R. Lawrence III), and texts that produce significant racial consequences, both those that do and those that do not refer explicitly to race (for example, the Unitcd States Constitution, The Slaughter-House Cases, 83 U.S. (16 IVall.) 36 (1873), and Unitcd States v. Cruikshank, 92 U.S. 542 (1876)).

8. Concomitantly, I hope this Essay can serve as something of a sourcefiuder for those interested in these issues, with a special emphasis on alerting readers to a varied and exciting body of legal scholarship that is beginming to emerge around critieal race theory. For discussions of this new trend in legal scholarship from various vantage points, see Robin D. Barnes, Race Consciousness: The Thematic Content of Racial Distinctiveness in Critical Race Scholarship, 103 HARV. L. REv. 1864 (1990); Richard Delgado, When a Story Is Just a Story: Does Voice Really Matter?, 76 VA. L. Rev. 95, 95 n.1, and passim (1990); Alex M. Johnson, Jr., The New Voice of Color, 100 YALE L.J. 2007 (1991); Duncan Kennedy, A Cultural Pluralist Case for Affirmative Action in Legal Academia, 1990 DukE L.J. 705; Gary Peller, Race Consciousness, 1990 DuKE L.J. 758; see also infra note 183 and accompanying text (discussiug Randall Kennedy's view of critical race scholars). 
first-year curriculum. Despite profound changes in constitutional, statutory, and common law, staggering centralization and elaboration of the state and the econoiny, the development of a new demographic profile in our student body and faculty, and radical alterations in the nature and practice of American lawyering, the basic core curriculum endures. ${ }^{9}$

In the "peripheral" areas of legal education (for example, in courses concentrating on legislation, skills training, or cross-disciplinary approaches) ${ }^{10}$ changes have been many. But compared with the bewildering diversity of required programs that have arisen over the past twenty years or so in undergraduate programs around the country, legal education is startling in its preservatiomsm. Though occasional serious attempts to restructure law school requirements have been mounted in the past, ${ }^{11}$ and although some provocative and interesting alternatives are presently being tried, ${ }^{12}$ the central courses have continued with

9. Kristine Strachan, Curricular Reform in the Second and Third Years: Structure, Progression, and Integration, 39 J. LEGAL Educ. 523, 523 (1989).

10. See Duncan Kennedy, The Political Significance of the Structure of the Law School Curriculum, 14 SETon Hall L. Rev. 1 (1983) (describing legal curriculum as a hard core of prepolitical, "private" law subjects surrounded by a periphery of secondary, political "public" law subjects). As I read Kennedy's thesis, he would situate constitutional law toward the public periphery of the curriculum, not in the private core. In one view, of course, the Constitution stands as a great arbiter between the realms of public and private. However, my argunnent is simply that constitutional law is firmly a part of legal education's core curriculum as that term is used in the canon debates. No law student can graduate without it. Cultural literacy for an American lawyer unequivocally requires some grounding in the United States Constitution.

11. See, eg., The Faculty of LaW of Columbia University, Summary of Studies in LEGAL Education (Herman Oliphant ed. 1928). The late Fred Snyder shared this study and much else with his Comparative Legal Education students, all in the inost wry, sly, diffident, humane, and cosmopolitan style. He will be missed.

12. Among the best known and most daring recent prograns is that at City University of New York Law School at Queens College, where first- and second-year students have encountered a significantly reordered group of required courses: (1) Liberty, Equality, and Due Process in Historical and Philosophical Context, (2) Law and a Market Economy, (3) Legal Research, (4) The Work of a Lawyer, (5) Responsibility for Injurious Conduct, (6) Civil and Criminal Procedure, (7) Law and Family Relations, (8) Public Institutions and Law, (9) Constitutional Structures and the Law, and (10) Lawyering and the Public Interest. CUNY LAW School aT QUEENS College, 1990-91 Catalog 10-13; see also John M. Farago, The Pedagogy of Community: Trust and Responsibility at CUNY Law School, 10 Nova L.J. 465 (1986) (describing how the issues of responsibility and trust have affected all aspects of CUNY's program); Charles Halpern, $A$ New Direction in Legal Education: The CUNY Law School at Queens College, 10 Nova L.J. 549 (1986) (discussing CUNY's innovative approach to legal education).

Stanford Law School has recently embarked on an experinent in which students may elect to participate in one (or even both) of two specialties: the Law and Business Concentration and the Lawyering for Social Change Concentration. Of course, upper-division concentrations leave most of the core inatters of first-ycar courses and constitutional law untouched, so this may be an innovation that proves the rule. See Stanford Law School, Public Interest Law at Stanford Law School 1 (May 7,1990 ) (unpublished description of program on file with author); see also Gerald P. López, Training Future Lawyers to Work With the Politically and Socially Subordinated: Anti-Generic Legal Education, 91 W. VA. L. REv. 305, 360-86 (1989) (discussing practical effects and implications of Stanford program). Harvard has experimented with one first-year section whose traditional core 
remarkable similarity and remarkably little serious challenge. ${ }^{13}$

However, with the rise of new modes of discourse in legal scliolarship, modes that challenge the legitimacy of long-unexamined assumptions, we inay begin to see soine of the same divergences, questions, and instabilities in legal education that we have seen elsewhere. Critical legal studies, law and economics, feminist theory, and inost recently critical race theory ${ }^{14}$ pose such challenges. At present, however, the core remains.

One can easily be of two minds about this state of affairs. Many of the criticisins launched against ideas of the canon in undergraduate programs can be launched against the standard law school curriculuin. Whose stories, needs, and interests are omitted, and whose heard? ${ }^{15}$ Are

curriculum has been both broken and innovatively interconnected. See Todd D. Rakoff, The Harvard First-Year Experiment, 39 J. LEGAL EDUC. 491 (1989).

13. I understand that there is difference as well as similarity to be found in a course called "Contracts" taught at Harvard by the revolutionary pedagogue, Christopher Langdell, in 1870, and post-Mentschikoff, post-Llewellyn courses of the same name taught at any law school in 1990 . Nor do I underestimate the activities of latter-day curriculum reformers, imcluding those at my own institution. See, e.g., Neil P. Cohen, The Process of Curriculum Reform, 39 J. LEGaL Educ. 535 (1989) (recommended curriculum changes while serving as chair of the Umiversity of Tennessee College of Law's curriculum committec and currently arguing that the process used in curricular reform may influence faculty approval of curricular reform programs). Nevertheless, in the context of the issues involved in this paper, I believe my premise stands. See Strachan, supra note 9 (starting from premise that legal education has remained unchanged for the last century).

14. See, e.g., Regina Austin, Sapphire Boundl, 1989 WIS. L. REV. 539; Barnes, supra note 8; Kimberlé Crenshaw, Demarginalizing the Intersection of Race and Sex: A Black Feminist Critique of Antidiscrimination Doctrine, Feminist Theory and Antiracist Politics, 1989 U. CHI. LEGAL F. 139; Jerome M. Culp, Jr., Toward a Black Legal Scholarship: Race and Original Understandings, 1991 DuKe L.J. 39 (1991); Delgado, supra note 8; Angela P. Harris, Race and Essentialism in Feminist Legal Theory, 42 STAN. L. REv. 581 (1990); Judy Scales-Trent, Black Women and the Constitution: Finding Our Place, Asserting Our Rights, 24 HaRv. C.R.-C.L. L. REv. 9 (1989).

15. The writings of Mari Matsuda provide one analysis of the voices that are excluded and can serve as practice aids for teachers who want to counteract patterns of exclusion in their own work. See, e.g., Mari J. Matsuda, Looking to the Bottom: Critical Legal Studies and Reparations, 22 HARV. C.R.-C.L. L. REv. 323 (1987) [hereinafter Matsuda, Looking to the Bottom] (urging critical legal scholars to study actual experience, history, culture, and intellectual tradition of people of color); Mari Matsuda, Affirmative Action and Legal Knowledge: Planting Seeds in Plowed-Up Ground, 11 HARV. WOMEN's L.J. I (1988) (arguing that legal education should encompass outside perspectives-especially from those "on the bottom"-to stimulate scholarly imagination). 
the materials presented ethnocentric? ${ }^{16}$ Male centered $?^{17}$ Race bound? ${ }^{18}$ To ask many of these questions is, of course, to answer them.

However, many will wonder, what else should be the focus of legal education if not the tools, elements, and creations of "our" legal culture? And though our materials may appear to be dommated by the concerns and problems of white western males of comfortable means, some will say that these concerns and problems are, in the main, umversal concerns and problems, resolvable by resort to umiversal principles.

In this Essay, however, I do not imtend to launch a full-scale consideration of these fascmating issues nor try to envision what an entire alternate curriculum (or a significantly altered approach to the present curriculum) might be. Instead, I will claim that legal educators should be able to reach relatively broad and rapid agreement on one theme of the canon debate: the centrahty of racial discourse to our field of intellectual endeavor.

16. Robert Williams, a Native American law teacher, believes they are. He has begun to recount Native American stories, funny and otherwise, interjecting them into legal discourse to see what light they bring to bear. See, e.g., Robert A. Williams, Jr., Taking Rights Aggressively: The Perils and Promise of Critical Legal Theory for Peoples of Color, 5 LAW \& INEQUALITY 103 (1987).

17. A number of commentators have attempted to analyze closely the messages about gender contained in particular casebooks and courses. See, e.g., Mary E. Becker, Commentary: Obscuring the Struggle: Sex Discrimination, Social Security, and Stone, Seidman, Sunstein \& Tushnet's Constitutional Law, 89 Colum. L. REV. 264 (1989) (casebook's presentation of law of sex discrimination obscures inequality between the two sexes by not questioning structural inequalities present in social security system); Mary I. Coombs, Crime in the Stacks, or A Tale of a Text: $A$ Feminist Response to a Criminal Law Textbook, 38 J. LEGAL Educ. 117 (1988) (feminist critique of textbook uncovering ways text presents women and addressing doctrinal issues that involve questions about gender); Nancy S. Erickson, Final Report: "Sex Bias in the Teaching of Criminal Law," 42 RUTGERS L. REV. 309 (1990) (comprehensively analyzing treatment of gender in criminal law as presented in criminal law casebooks); Nancy S. Erickson \& Mary A. Lamanna, Sex-Bias Topics in the Criminal Law Course: A Survey of Criminal Law Professors, 24 U. MICH. J.L. REFORM 189 (1990); Mary J. Frug, Re-Reading Contracts: A Feminist Analysis of a Contracts Casebook, 34 AM. U.L. REV. 1065 (1985) (examining treatment of women in contracts casebook and noting "maleness" of casebook); Carl Tobias, Gender Issues and the Prosser, Wade and Schwartz Torts Casebook, 18 GoldeN GATE U.L. REV. 495 (1988) (analyzing gender bias in casebook and examining subtle ways casebook editors treat women). Others have suggested ways of integrating gender issues into tort law, a paradigmatically core-curriculum course. See, e.g., Leslie Bender, $A$ Lawyer's Primer on Feminist Theory and Tort, 38 J. Legal Educ. 3 (1988); Lucinda M. Finley, $A$ Break in the Silence: Including Women's Issues in a Torts Course, 1 YALE J.L. \& FEMINISM 41 (1989).

18. Numerous authors have considered race as a feature of contemporary legal education and legal pedagogy. See, e.g., Patricia J. Williams, The AlchemY of RaCe AND Rights 80-97 (1991) (chapter entitled "Crimes Without Passion"); Kimberlé W. Crenslıaw, Foreword: Toward a Race-Conscious Pedagogy in Legal Education, 11 NAT'L BLACK L.J. 1 (1989) (discussing difficulties minority students face in the classroom and suggesting ways to overcome them); Jerome M. Culp, Jr., Autobiography and Legal Scholarship and Teaching: Finding the Me in the Legal Academy, 77 VA. L. REV. 539 (1991) (black law professor begins law courses with personal narrative); Gerald P. López, The Work We Know So Little About, 42 STAN. L. REv. 1 (1989) (using narrative to give another perspective); Mari J. Matsuda, When the First Quail Calls: Multiple Consciousness as Jurisprudential Method, 11 WoMEN's RTS. L. REP. 7 (1989) (urging lawyers to see the world from the viewpoint of the oppressed). 


\section{Its Advantages}

A central feature of the debate in the larger acadeiny over the canon has been the insistence by one side that inatters of race deserve greater attention than they have traditionally received. ${ }^{19}$ These advocates urge exploration of the lives, concerns, and experiences of people of color, celebration and criticism of their creations, and analysis of the dominant attitudes, ideas, and institutions that have contributed to the subordinate status these people have experienced.

It goes without saying that there is scarcely a scholar today who would object to the study of the work, life, or concerns of a black person simply because her skin was black. Nevertheless, calls for the inclusion of race-focused study have met with strong resistance, including the assertion that texts of appropriate quality are lacking (the "qualified-pool problem") and the observation that there are inadequate resources to implement such expansion. ${ }^{20}$

Members of law school communities are certainly in no better posi-

19. Houston Baker, an English professor at the University of Pennsylvania, has charged, for example, that in many cases a continued emphasis on western civilization in core curricula constitutes " 'a willful ignorance and aggression toward Blacks.' " O'Brien, supra note 3, at 26. Jonathan Culler, director of the Society for Humanities at Cornell University, similarly observed:

"I'm not saying that Black students[] cannot respond to or benefit from great works from dead white men. They can and they do. But when you tell students that the books you are assigning them are the great works of the universe that address our common humanity, and all the books that do this happen to be written by dead white men ... the effect is to deny to some groups their own humamity ...."Id.

20. These particular recurring objections merit some comment here. First is the implied or explicit assertion of a qualified-pool problem, the argninent that worthy texts by authors of color and female authors are simply too scarce to support the project. According to this view, those texts we currently honor and celebrate have achieved their status through the meritocratic application of standards of "quahty" over the centuries. See Irving Howe, The Value of the Canon, NEw REPuBlic, Feb. 18, 1991, at 40, 44 (arguing that we must rccognize that on the whole the "great works" of literature and thought through the centuries were the achievements of men, even though the circumstances under which men have so dommated the field may be excoriated). The test-oftime assumption has been contested by authors who have pointed out that neither the birth nor the endurance of a work is the result of neutral processes. See LAURENCE SChWARTZ, Creating Faulkner's Reputation: The Polmics of Modern LITERARy Criticism (1988) (describing how a "confluence of literary, cultural, and commercial forces created and shaped Faulkner's literary reputation" in the post-war climate); Earl Shorris, In Search of the Latino Writer (Book Review), N.Y. Times, July 15, 1990, § 7, at 1, col. 1 (discussing the exclusion of Latino writers froln the canon of American literature). Other writers have attempted the difficult job of critically analyzing the silences and absences in the received canon. See generally TILLIE OLSEN, Silences (1965) (discussing the influence of sex, class, and color on the creation of literature and stating that "[1]iterary history and the present are dark with silences: ... some silences hidden; some the ceasing to publish after one work appears; some the never coming to book form at all"); VIRGINIA WooLF, A ROOM OF ONE's OWN (1929) (arguing that women's writing has been "impoverished by the limited access women have had to life," id. at x); Toni Morrison, Unspeakable Things Unspoken: The Afro-American Presence in American Literature, 28 MicH. Q. REV. 1 (1989) ("certain absences [in American literature] are so stressed, so ornate, so planned, they call attention to themselves," $i d$. at 11). A recent anthology purports to demonstrate a much larger qualified pool than had previously been supposed. See The Heaty ANTHology of American Literature (Paul Lauter ed. 1990) 
tion than anyone else in this racially divided country to achieve a general consensus on matters of color. Nevertheless, our particular heritage as American lawyers, as observers and interpreters of American law, puts us in a position to enter this discourse about the place of race in the curriculuin at a more advanced stage than our academic counterparts elsewhere. Argunents about a qualified pool of race-related texts of genuine significance, for example, or about the problem of priorities given limited resources, may plague and vex our colleagues in other parts of the university but they appear simply beside the point in a discipline whose canon by anyone's reckoning inust include, for example, the founders' Constitution, the thirteenth, fourteenth, and fifteenth amendments, and Brown v. Board of Education. ${ }^{21}$

At present, legal education's advantage in this regard exists more as an opportunity than as a fully realized achievement. It is an opportunity we should enthusiastically grasp. Our canon is already an integrated one and should be consciously taught as such. American law students should not leave the law schools of the late twentieth century until they have received a thorough and explicit grounding in the role that race has played in the creation and transformation of central legal institutions. The power and burden of race, botll past and present, should be seen as indispensable parts of minimal cultural and constitutional literacy for the legal practitioners and theoreticians we send forth into the bar and the world.

(providing a selection of authors of diverse identities and backgrounds in terms of race, class, and gender).

A second common objection to a race-conscious curriculum is that there are inadequate resources for its implementation. The argument is that, given the limited time and money devoted to education, attention needs to be focused on the "fuudamentals," not on peripheral "extras." See E. HIRSCH, supra note 4, at 144-45 ("If the contents of our existing extensive curriculum were listed openly ... we would see that much of the information now being conveyed to our children is wasteful of precious opportunities." (emphasis added)). Some commentators havc articulated the uncousciously privileged assumptions that may underlie this assessment of the fundamental and the peripheral. See Peggy McIutosh, White Privilege and Male Privilege: A Personal Account of Coming to See Correspondences Through Work in Women's Studies 14 (1988) (Working Paper No. 189, Wellesley College Center for Research on Women) (listing in a consciousness-expanding way the conditious most white women can assume will hold true for them in daily life). Others have directly urged decentering. See, eg., Atlas, supra note 3, at 75 (During Stanford's reform of its westeru civilization requirement, the leader of a black student organization stated: "If you think we are talking about a handful of good books you are mistaken .... We arc discussing the foundations of edueation in America and the acceptance of Euro-America's place in the world as contributor, not creator." "Id. (emphasis added)).

21. 347 U.S. 483 (1954). 
II

\section{Race IN A Law School Classroom: Case Study}

I want now to put more flesh on the bones of my argument by exploring in greater depth the reasons and ways that race is so central to the American legal story. Rather than argument, I choose narrative. Rather than sketch a general race-conscious description or history of American legal institutions, ${ }^{22}$ I will tell some stories from my own classes, which I hope will provide a sense of why I say race is such a key lens for the viewing and understanding of American law and why teaching froun this perspective can make for exciting and useful times in class.

The inain stories I want to tell involve my teaching of a seiminar on "Race and Gender im American Law" and a large class on "Discrimination and the Law." However, I also teach first-year Property and an upper-division course called "Gratuitous Transfers" (covering wills, trusts, and future interests), and both these courses deserve some mention in regard to race.

\section{A. Property Class and Gratuitous Transfers Class}

\section{Roots of Title in the New World}

A number of basic property casebooks now mclude early attention to Native American land claims. ${ }^{23}$ The case of Johnson and Graham's Lessee v. M'Intosh, ${ }^{24}$ for example, is a fascinating vehicle for the introduction of notions of occupancy, possession, chains of title, the stark juxtaposition of positivist and natural law ideas of authority, and the relationship between property and sovereignty. It also, however,

22. For those interested in such a description, the inosaic of resources is vast. I offer the following without the least clain of coinprehensive coverage. See, e.g., DERRICK A. BELL, JR., RACE, RACISM AND AMERICAN LAW (2d ed. 1980); VinCENT HARDING, THERE Is a RIVER: THE Black Struggle for Freedom in America (1981); A. LeON Higginbotham, JR., IN the Matter of Color: Race and the American legal Process: The Colonial Period (1978); MAXine H. Kingston, China MEN 152-59 (1980) (chapter entitled "The Laws"); Anthony E. Cook, Beyond Critical Legal Studies: The Reconstructive Theology of Dr. Martin Luther King, Jr., 103 HARV. L. REV. 985 (1990); Kimberlé W. Crenshaw, Race, Reform, and Retrenchment: Transformation and Legitimation in Antidiscrimination Law, 101 HARV. L. REV. 1331 (1988); Randall L. Kennedy, McCleskey v. Kemp: Race, Capital Punishment, and the Supreme Court, 101 HARV. L. REV. 1388 (1988); Michael A. Otivas, The Chronicles, My Grandfather's Stories, and Immigration Law: The Slave Traders Chronicle as Racial History, 34 ST. LouIs U.L.J. 425 (1990); Rennard Strickland, Genocide-at-Law: An Historic and Contemporary View of the Native American Experience, 34 U. KAN. L. REV. 713 (1986).

23. See, e.g., Richard H. Chused, Cases, Materials and Problems in Property 94 160 (1988) (section entitled "Native American Land Claims: Sovereignty, Cherokee Reinoval, and Modern Non-Intercourse Act Litigation"); Charles Donahue, JR., Thomas E. Kauper \& Peter IV. MARTin, Cases and Materials on Property: AN INTRoduction to the Concept AND THE INSTITUTION 30-42 (2d ed. 1983) (discussing Johnson and Graham's Lessee v. M'Intosh, 21 U.S. (8 Wheat.) 543 (1823)); Charles M. HaAR \& Lance Liebman, Property and Law 3-32 (2d ed. 1985) (section entitled "Cham of Title: European Versus Native American").

24. 21 U.S. (8 Wheat.) 543 (1823). 
reminds and informs us of the racial displacement and usurpation that attended the arrival of European settlers and the birth of the nation. It is for this latter lesson that I beheve the case is most valuable and irreplaceable.

In Johnson and Graham's Lessee the Court was asked to choose between two groups of opposing white litigants. One side traced title back to original grants from the Illinois and Piankeshaw nations; ${ }^{25}$ the other side claimed title to the same land through grants from the United States. The latter claimants rehed on a chain of title that started with Enghish "discoverers" and descended through an English crown grant to colomists, the armed conquest of territory in the name of England by the Virginia colony, the ceding of the Virginia territory "covered by Indians" to the newly created United States, and ended with a grant from the United States to the hitigants' immediate predecessors in title. ${ }^{26}$

Justice Marshall decided that the titles received fron the federal government were superior to those received from the tribes. His Genesislike explanations of this result are rivetimg:

On the discovery of this immense continent, the great nations of Europe were eager to appropriate to themselves so much of it as they could respectively acquire. Its vast extent offered an ample field to the ambition and enterprise of all .... [I] t was necessary [for the European powers] ... to establish a principle, which all should acknowledge as the law by which the right of acquisition, which they all asserted, should be regulated as between themselves. This principle was, that discovery gave title .... ${ }^{27}$

Marshall went on to explain:

Conquest gives a title which the Courts of the conqueror cannot deny, whatever the private and speculative opinions of individuals may be, respecting the original justice of the claim which has been successfully asserted. The British government, which was then our government, and whose rights have passed to the United States, asserted a title to all the lands occupied by Indians, within the chartered limits of the British colomes. ... These claims have been maintamed and established as far west as the river Mississippi, by the sword. The title to a vast portion of the lands we now hold, originates in them. It is not for the Courts of this country to question the validity of this title $\ldots .^{28}$

25. Id. at $548-49$.

26. Id. at $572-73$.

27. Id.

28. Id. at 588-89. Justice Marshall's attitudes toward the history he recounts and interprets are surely complex, though the impact of his judgment may have been brutally simple. In another case, Cherokee Nation v. Georgia, 30 U.S. (5 Pet.) 1 (1831), the Cherokee Nation petitioned the Court for an injunction restraining the State of Georgia from exercising authority over territory secured to the Cherokee by treaties with the United States. Marshall reflected:

If courts were permitted to indulge their sympathies, a case better calculated to excite them can scarcely be imagimed. A people once numerous, powerful, and truly independent, 
The centrality of racial issues to the resolution of this property issue was recognized by the Chief. Justice, who also remarked that the "character and religion" of the Native Americans who lost their land "afforded an apology for considering them as a people over whom the superior gemius of Europe might claim an ascendancy."29

\section{Slavery}

If the racially charged "discovery" and conquest from which so many American land titles spring is one demonstration of the fact that race is at the heart of American property law, then surely the institution of slavery is another. Its legacy was visible in my Gratuitous Transfers course in cases involving race discrimination im devises, bequests, and inter vivos trusts. These examples illustrate the way that publicly sanctioned private acts by decisionmakers who own and control wealth have historically constructed and reinforced racial exclusions and inequalities. ${ }^{30}$ But slavery itself, not simply its legacy, should be part of the first-

found by our ancestors in the quiet and uncontrolled possession of an ample domaim, gradually sinking beneath our superior policy, our arts and our arms, liave yielded tlieir lands by successive treaties, each of which contains a solemn guarantee of the residue, until they retain no more of their formerly extensive territory than is deemed necessary to their comfortable subsistence. To preserve this remnant, the present application is made.

Id. at 14. He denied the injunction. Id. at 20.

For further discussions on the law and its relationship to Native Americans, see generally Milner S. Ball, Constitution, Court, Indian Tribes, 1 AM. B. FouND. RES. J. 3 (1987) (exploring the impact of constitutional law upon Native American tribes); Strickland, supra note 22 (arguing that law has played a key role in the genocidal extermination of Native Americans as well as an important role in Native Americans' struggle for survival); Robert A. Williams, Jr., Documents of Barbarism: The Contemporary Legacy of European Racism and Colonialism in the Narrative Traditions of Federal Indian Law, 31 ARIz. L. REV. 237 (1989) (discussing early nineteenth-century Cherokee Nation's views of tribal sovereignty and arguing that modern public discourses seek to confine tribalisni).

29. Johnson and Graham's Lessee, 21 U.S. (8 Wheat.) at 573. The significance of the conquest theory of title has not gone unreinarked by law students. The Law Student Division of the American Bar Association passed a "canon expanding" resolution in 1989 urging the Section on Legal Education and Adinissions to include as an interpretation to ABA acereditation standard 302(a)(1) the following:

In keeping with the commitment of Standard 212 to providing full opportunities for the study of law and entry into the profession by qualified members of groups that have been victins of discrimination in varions forms, each law school is encouraged in such instruction to cover alternative perspectives on the history and developinent of the law that nuay educate students about the doctrines by which Europcan settlers acquired and retained sovereignty over land in the New World.

Law Student Division, Report to the Honse of Delegates Law Student Division 105 (1989) (American Bar Association No. 89-17). The report accoinpanying the resolution nuade clear that the conquest theory of property acquisition is the primary legal doctrine contenuplated by the law students who drafted this measure. See id. at 106. The report pointed out that the conquest theory had continuing vitality well into the nineteenth century and that it is relevant to an understanding of international law today. Id. at 112. Whatever the obvions difficnlties with having the ABA impose a detailed list of theories to be covered by teachers in American law schools, the points raised by this resolution are iniportant ones.

30. See, e.g., Evans v. Abney, 396 U.S. 435 (1970) (involving land conveyed in trust to city for 
year property course. A number of property teachers, both on their own initiative and in response to student urging, have im fact begun to address the question of slavery. ${ }^{31}$

Following their lead, I have tried various ways of integrating the subject into my property class. In my first attenupt the topic functioned nore as a disconnected sermon than as an organic part of the whole. ${ }^{32}$

use as a whites-only park); Shelley v. Kraemer, 334 U.S. 1 (1948) (regarding restrictive covenant to exclude blacks from owning or occupying property); Charlotte Park and Recreation Comm'n v. Barringer, 242 N.C. 311, 88 S.E.2d 114 (1955), cert. denied, 350 U.S. 983 (1956) (concerning clause that provided land wonld automatically revert to grantor if nonwhites used land granted for park purposes). There is another strange race theme in gratuitous transfers, at least for those teaching and practicing in the South. It turns out that if you are researching property questions and decedents' estates questions in Teunessec, for example, it is not at all uncominon to find yourself sinack in the iniddle of slavery cases. These precedents are currently cited on propositions involving, say, treatınent of realty versus personalty for purposes of descent and distribution or fraud on the inarital share.

31. Personal conversations with Professors Mary Ann Glendon, Duncan Kennedy, Lance Leibman, and Frank Michelman of Harvard Law School (Spring 1988). Slavery-related readings used or suggested to ine by these property teachers included the following: Gorman v. Campbell, 14 Ga. 137 (1853) (hiring slave is contract of bailment and as a result hirer of slave liable to owner for slave's death); Commonwealth v. Aves, 35 Mass. (18 Pick.) 193 (1836) (narrow construction of the fugitive slave law by Justice Shaw); State v. Jin, 48 N.C. (3 Jones) 348 (1856) (owner of slave who was on trial for capital felony was competent witness for slave despite owner's pecuniary interest in slave's survival); State v. Mann, 13 N.C. (2 Dev.) 167 (1829) (person who has hired slave cannot be hable to an indictment of battery on slave because right to inflict physical discipline is necessary corollary of chattel slavery); Snee v. Trice, 1 S.C.L. (2 Bay) 345 (1802) (English law of master's vicarious liability for acts of servants inust be adapted when applied to master's liability for miscouduct of slaves); D. BELL, supra note 22, at 3-5 (section entitled "The Emancipation Proclamation"), 8-9 (section entitled "Abolition of Slavery in Northern States"); ROBERT M. Cover, JUstice ACCuSED: ANTISLAVERY AND THE Judicial Process 1-6, 119-23, 131-32, 147-54 (1975); Eugene D. Genovese, Roll, JoRdan, Roll: The World the Slaves MADE 25-28, 35 36, $45-49$ (1974); HAROLD W. HOROWITZ \& KENNETH L. KARST, LAW, LAWYERS \& SOCIAL CHANGe 103-109 (sections entitled "The Emancipation Proclamation: Lawmaking by the Executive" and "The Emancipation Proclamation") (1969); ANTHONY T. KRONMAN \& RICHARD A. Posner, The Economics of Contract Law 253-60 (1979); Kenneth M. Stampp, The PeCuliar Institution: Slavery in the ANTE-Bellum South 206-216 (1956) (general description of slave codes); Robert J. Cottrol, Liberalism and Paternalism: Ideology, Economic Interest and the Business Law of Slavery, 31 AM. J. LEGAL HIST. 359, 359-68 (1987); Andrew Fede, Legitimized Violent Slave Abuse in the American South, 1619-1865: A Case Study of Law and Social Change in Six Southern States, 29 AM. J. LEGAL Hist. 93 (1985); Paul Finkelman, Slaves as Fellow Servants: Ideology, Law, and Industrialization, 31 AM. J. LEGAL HIST. 269 (1987); see also R. CHuSed, supra note 23, at 161-251 (section entitled "Black Persons and Property Ownership" covering slavery and the transition to freedon as well as housing segregation and racial property restrictions); Margaret A. Burnham, An Impossible Marriage: Slave Law and Family Law, 5 LAw \& INEQUALITY 187 (1987) (discussing slave family life, laws denying slave inarital rights, and the current effects of those laws).

In addition, Donald Weidner of Florida State University has described an extensive seginent on slavery and its aftermath that he regularly incorporates into his first-year property class. His description was part of a workshop conducted on October 31, 1991, at a conference at ClevelandMarshall College of Law on "The Justice Mission of American Law Schools."

32. In that atteinpt I assigned the following: Prigg v. Pennsylvania, 41 U.S. (16 Pet.) 539 (1842) (announcing the view that slavery enjoyed special constitutional status); DERRICK BELL, AND We ARe Not SAVED: The Elusive Quest for RACIAL Justice 26-50 (1987) (relating "The 
In my second attempt I saved slavery as a culminating topic for the end of the course. We had begun by examining "Property as a Cultural Institution," and the final class was entitled "Property as a Cultural Institution Revisited." In examining slavery and our society's tolerance of the treatment of human beings as property, we reflected back on themes encountered earlier in the course. ${ }^{33}$ Our discussion explored the values and dangers of property regimes and whether our nation's past experiences with slavery and its abohtion might guide us in making judgments about the future of our present system of property. This approach worked much better than the approach of the previous year but still left mucl to be desired in the level of discussion we were able to reacli. In any case, $I$ beheve the first-year property course requires some encounter with the institution of cliattel slavery. ${ }^{34}$ So I will keep trying.

The instances where race intersects the property syllabus are impor-

Chronicle of the Constitutional Contradiction"); K. STAMPP, supra note 31 (selected excerpts); R. CHuSED, supra note 23, at 185 (two cases from the slavery section). No small part of the sermonlike quality of the lesson sprang from my worries about the psycho-racial dynamics of the classroom. See infra text accompanying notes 125-40 (discussing the "underground classroom").

33. Slavery-related readings included excerpts from Abraham Lincoln, Preliminary Emancipation Proclamation (Sept. 22, 1862) (promising to recommend that loyal citizens be compensated for the loss of slaves), reprinted in 5 THE COLLECTED WORKS OF ABRAHAM LINCOLN 433-36 (Roy P. Basler ed. 1953); Abraham Lincoln, The Emancipation Proclamation (Jan. 1, 1863) (oinitting any mention of compensation), reprinted in 6 THE COLLECTED WORKS OF ABRAHAM LINCOLN 28-30 (Roy P. Basler ed. 1953); U.S. CONST. amend. XIII (abolishing slavery); U.S. CoNST. amend. XIV, $\S 4$ (declaring in the often-omitted $\S 4$ that "neither the Umited States nor any State shall ... pay ... any claim for the loss or emancipation of any slaves"); D. BEL,L, supra note 32, at 26-50 (imagining a time traveler pleading with the framers to reject slavery); Eric Foner, Rights and the Constitution in Black Life During the Civil War and Reconstruction, 74 J. AM. HIST. $863,871-72,877-79$ (1987) (discussing the claim by freedmen that they had a right to a share in the land of their former masters); Juliet E.K. Walker, Whither Liberty, Equality or Legality? Slavery, Race, Property and the 1787 American Constitution, 6 N.Y.L. ScH. J. HuM. RTS. 299 (1989) (reconciling slavery with the Declaration of Independence and the Constitution based on the founders' vision that property preserves liberty); Comment, Another Look at Our Founding Fathers and Their Product: $A$ Response to Justice Thurgood Marshall, 4 Notre DAME J.L., ETHIcs \& PUB. PoL'y 73 (1989) (authored by Edward L. White III) (summarizing the slavery provisions of the Constitution of 1787 ).

I added excerpts from the thought-provoking introduction and afterword of an anthology by C.B. MacPherson. See Property: Mainstream ANd Crirical Positions 1-13 (entitled "The Meaning of Property"), 199-207 (entitled "Liberal-Democracy and Property") (C.B. MacPherson ed. 1978). MacPherson suggested that a "good society" would be founded in important part upon property rights but those rights would be recast not simply in terms of an "individual right to exclude others from the use or benefit of something," id. at 205, but also "the right not to be excluded from the use of those things (including society's productive powers) which are the achicvements of the whole society," id. at 206.

34. Race, of course, oceurs in plenty of other property contexts besides those of Native American land claims and slavery. Zoning and land-use planning are both racially charged areas. Landlord-tenant law can be taught so that students learn about the ways race and movements for racial justice have affected the development of modern property law. For a discussion of a particular instance of these effects, see Edward H. Rabin, Symposium: The Revolution in Residential LandlordTenant Law: Causes and Consequences, 69 CORNELL L. REv. 517 (1984), excerpted in R. CHUSED, supra note 23, at 724-27; see also Multammad I. Kenyatta, Critical Footnotes to Parker's 
tant but they are not the heart of my argument. ${ }^{35}$ The reason I believe law teachers might be able to reach consensus about the centrality of race in American law has less to do with these instances than with the Constitution. Race is and should be recognized as central to the Constitution, which is, of course, central to the law school curriculuin. The remaimder of this Essay will therefore focus on iny experiences teaching aspects of constitutional law in a large-class course on discrimination law. ${ }^{36}$

\section{B. Discrimination Class}

\section{Background}

My second fall in law teaching I agreed to teach a course called "Discrimination and the Law."37 When the first day of class arrived and

"Constitutional Theory," HARV. BLaCKLETTER J., Spring 1985, at 49 (reminding scholars to accord due credit to the impact of popular movements of people of color on constitutional law as well).

35. However, im my view race is a relevant topic for every law school course and eventually should be thoroughly integrated into the "core" and "peripheral" parts of the curriculum. I leave exploration of these matters for another day.

36. I will occasionally indulge in minor fictions when necessary to protect the identity of individuals and will sometimes include (without special designation) relevant experiences from a seminar on "Race and Gender in American Law" that I taught in the spring of 1989 and again in 1990.

37. As a new teacher still gettimg to know the student body, just beginning to glimpse the depth of commitment required for adequate class preparation, and only starting to realize how potentially debilitatimg the pressures of the tenure process can be, I was hesitant to do so. I questioned the wisdom of jumping into a subject area that might put me at odds with many of my students and be viewed as peripheral by my colleagues.

People of color and white women in legal scholarship have frequently voiced the concern that their work will be taken less seriously, viewed as excessively narrow, or even received with hostility if it focuses primarily on matters of race or gender. Sometimes this concern is self-imposed, sometimes urged by well-intentioned, and perhaps well-informed, others. See, e.g., Richard Delgado, Commentary: The Imperial Scholar: Reflections on a Review of Civil Rights Literature, 132 U. PA. L. REV. 561, 561 (1984) (commenting that when he first began teaching law he was told "to "play things straight' . . . to estabhish a reputation as a scholar in some mainstream legal area and not get too caught up in civil rights or other 'ethnic' subjects."); Deborah L. Rhode, The "No-Problem" Problem: Feminist Challenges and Cultural Change, 100 YALE L.J. 1731 (1991) (recounting that when she first expressed interest in teaching a course on sex discrimination at Stanford her dean was negative: "Not only was it a field he diplomatieally described as 'mush,' but it would 'brand nee as a woman.'" Id. at 1733); Ensuring a Rainbow After the Storm: Recent Initiatives to Institutionalize Pluralism on Predominantly White Campuses, Higher Educ. ExTENsion SERvice ReV., Spring 1990, at 1, 5 [hereinafter Ensuring a Rainbow] (citnig reports that the research of black faculty members "often renained unaccepted and marginalized, in part because of the ethnic focus"); Gerald P. López, Remarks at the Meeting of the Law \& Humanities Section of Association of American Law Schools (Jan. 1990) (tape on file with author) (criticizing and exploring the roots of the common advice given to people of color not to "ghettoize" themselves by writing about race); Testimiony of Emma Coleman Jordan, AM. A. L. Schools NEwSLETTER, Summer 1988, at 3J (on file with author) (speech on behalf of the Society of American Law Teachers) ("[f]or many women and minority scholars, the standard advice of tenure committees is to avoid race- or genderdiscrimination law"). But see Stephen R. Barnett, Get Back, NEw RepuBlic, Feb. 18, 1991, at 24 (reporting that academics of color are being typecast by their ethnic backgrounds and are experiencing pressure to do color-conscious scholarship).

On the other hand, given my own values and commitments, I was no less disturbed at the 
I looked at the sixty-plus students arrayed in their rising ranks before me, I was apprehensive. I knew I did not want to teach this class as a straight doctrinal course. The subject matter and the times seemed to call for another approach.

If the course would be different from my other large classes, it would also be different from the seminar on Race and Gender I had taught the semester before. The level of trust, resulting candor, and subtlety that a group of twelve can establish is radically different from that achievable by a group of sixty-five. And the ratio of African-American to white students im a large class, unlike in a seminar, had no chance of reaching a level different than the overwhelmingly white claracter of most classroouns at our institution given the racial composition of our student body as a whole. ${ }^{38}$

prospect of conscious avoidance. To the credit of my school's administrators, they insisted that my fears that this choice of subject matter might result in a devaluation of iny work were unworthy both of ine and of the institution.

38. The only substantial group of students of color at iny law school, as at many law schools in the Southeast, is black. Over the years, the number of Latino, Asian-American, and Native American students we have enrolled is sinall to nonexistent. Approximately $8 \%$ of our student body is Afriean-American; approximately $17 \%$ percent of Tennesseeans are African-American. One sernester when I was teaching iny "Race and Gender" semninar with a group of students that paralleled the school's racial coinposition, I asked students to recall a time or event or setting in their lives when they had felt themselves to be in a racial minority. Several white students hiterally had no such minority experience and none reported such an experience in an educational institution.

By happenstance, the first time I taught this seminar, however, the group contained a bare majority of whites. Interestingly, this demographic fact led most of the v/hite participants to feel as if they were outnumbered. Many reported their impression that the class was in some significant way a black environment, despite all the obvious ways in which that was clearly not the case. (We were, after all, a small class situated in a predominantly white institution, conceived, taught and graded by a white professor, in which the majority of participants were white.) I believe that this racial context inade for a significant learning experience for white students and dramatically altered both the tone of discussions and the level of sophistication with which we approached certain racially charged topics.

Obviously there is more to this dynamic than a mere head count. The teacher, the subject, the readings, the entire context, play a role. Nevertheless, the observation that a black-dominated learning environment (or a less overwhelmingly white-dommated one) can be good for students of both races strikes me as important and worth the attention of tcachers interested in truly pluralistic educational experiences for students who will be functioning in an increasingly multicultural and multiracial environment.

Inconclusive but provocative evidence about the advantages for black students of a blackdominated learning environment further underscores these points and suggests further action. See, e.g., Jacqueline Fleming, Blacks in College: A Comparative Study of Students' SUCCESS IN BLACK AND IN WHITE INSTITUTIONS (1984) (empirical evidence suggests that black students at black-dominated colleges show inore progress than their counterparts at white colleges); cf. Joan Morgan, Retention at Black Colleges Notable-According to the Figures, BLACK Issues HIGHER EDUC., Feb. 1, 1990, at 22 (evidence suggests that black colleges are more successful than white colleges in retaining black students until they graduate). An African-American colleague of mine in the English Department at iny university once remarked, "You know, whenever black enrollment in my courses reaches the 50\% mark, my black students 'suddenly become' brilliant. They become brilliant." On the importance of providing students of color in predominantly white institutions with safe spaces and a process for mutual analysis, debriefing, and support, see Charles 


\section{The First Class}

So it was with both excitement and apprehension that I stepped to the front of the room, picked up a piece of chalk, and drew a large circle on the blackboard. "This is all the people in the world," I said. ${ }^{39}$ I then drew a line down the middle of the circle. "This," I said, pointmg to one of the halves, "is all the men in the world."

And so I continued, demarcating narrower and narrower wedges in the circle, explaining that one was all the white men in the world, the next was all the white inen in the industrialized world, the next and last (by now timy) wedge was all the white, affluent, well-educated men in the industrialized world. ${ }^{40}$ I remarked that for most of us, the world of that narrow shiver dominated much or inost of our experience and our intellectual attention. Even those of us in the rooin who were not white, and/ or male, and/or froin affluent, well-educated backgrounds had certainly been devoting inuch of ourselves to studying a world of concepts and discourse developed almost exclusively by white, western, affluent, educated men.

My comments continued in the following vein: "Obviously, when we look at things this way, we can see that inuch of our ordinary focus is terribly narrow. But that's not the worst of it. You see, this hittle wedge soinehow gets itself up not just as one inore wedge in a circle of varying wedges but as the center." I erased the wedges and redrew our diagram as a small central circle at the middle of the larger one.

After a few words about the center and the margin, about the ines-

Lawrence, Reclaiming the Slave Scrolls: The Liberationist Teacher as Healer (Nov. 1990) (unpubhished manuscript on file with author).

For an argument that white students may be liberated from a sensc of racial superiority by attending a predominantly black college or university, see Charles V. Willie, Black Colleges Should Recruit and Admit More White Students, Chron. Higher Educ., Mar. 13, 1991, at A48, col. 1. For a response to this argument, see Letter to the Editor from William A.T. Byrd, Chron. Higher Educ., Apr. 10, 1991, at B4, col. 1 (arguing that it is the responsibility of predominantly white colleges to develop their own programs to change the inind-set of their students).

39. The idea for this beginning came straight from Patricia A. Cain's article, Teaching Feminist Legal Theory at Texas: Listening to Difference and Exploring Connections, 38 J. LEGAL EDuc. 165, 168 (1988). The article gave me the courage to try a number of things I would never otherwise have drcamed of. Further, it convinced ine of the importance of teachers modeling for each other and cominunicating with each other in concrete detail about pedagogy and was one of the inspirations for this Essay.

40. There was obvionsly a politics to this circle. By choosing categories of gender, race, and class, I suppressed others, creating tacit alliances and divisions. This system allowed me to move sequentially from larger to smaller slices, which has a certain logic and appeal. Afterward I noticed, however, that by beginning with gender, I placed myself (an educated, white, Christian, thin, heterosexual, presently abled U.S. citizen with a comfortable income) in the category of tacitly oppressed or subordinated at the first cut, and therefore from then on. How convenient.

The categories are provisional, not essential, as I tried to make clear in the course and as I want to make clear here. Other categories of difference (such as nationality, religion, sexual orientation, geograplic region, etlunicity, physical or mental disability, language, accent), as well as other orderings of categories, might well be salient and could be pedagogieally invaluable. 
capable fact that one's position in this circle conditions one's view of the world, ${ }^{41}$ about the false sense of universality that can so easily come to those in the center, I read aloud from a book by Bell Hooks, a black feminist theorist:

To be in the margin is to be part of the whole but outside the main body. As black Americans hiving in a small Kentucky town, the railroad tracks were a daily reminder of our inarginality. Across those tracks were paved streets, stores we could not enter, restaurants we could not eat in, and people we could not look directly in the face. Across those tracks was a world we could work in as maids, as janitors, as prostitutes, as long as it was in a service capacity. We could enter that world but we could not live there. We had always to return to the margin, to cross the tracks, to shacks and abandoned houses on the edge of town.

There were laws to ensure our return. To not return was to risk being punished. Living as we did-on the edge-we developed a particular way of seemg reality. We looked both from the outside in and . . . from the inside out. We focused our attention on the center as well as on the margin. We understood both. This mode of seeing reminded us of the existence of a whole universe, a main body made up of both margin and center. Our survival depended on an ongoing public awareness of the separation between margin and center and an ongoing private acknowledginent that we were a necessary, vital part of that whole.

This sense of wholeness, impressed upon our consciousness by the structure of our daily hives, provided us an oppositional world view-a mode of seenig unknown to most of our oppressors, that sustained us, aided us in our struggle to transcend poverty and despair, strengthened our sense of self and our solidarity. ${ }^{42}$

I explained that one of the goals of our course would be for us to think about, histen for, and pay attention to the inargin. We would strain to hear voices (including at times our own voices) from the edge. We, I said, would try to recoginze and act upon the paradox that those in the center are in some important ways the most ignorant and parochial. Those at the center typically lack the knowledge, the experience, and the

41. See Alison M. Jaggar, Feminist Politics and Human Nature 353, 385-89 (1983) (chapter entitled "Feminist Politics and Epistemology: Justifying Feminist Theory"); Kimberlé Crenshaw, supra note 18; Matsuda, Looking to the Bottom, supra note 15; Martha Minow, The Supreme Court, 1986 Term-Foreword: Justice Engendered, 101 HARV. L. REV. 10 (1987).

42. Bell HoOKS, Feminist TheORY From MARgIN to CENTER ix (1984) (suggesting that feminists must look to the experiences of women at the margin). For more views from the margin, see Robert M. Brown, UNEXPECTEd News: ReAdING THE B1ble WITH THIRD World Eyes (1984) (suggesting that through rereadings of the Bible from the perspective of Christians in the Third World, Christians from the developed world "may get a new understanding of what the biblical message says to us," id. at 14); Jamaica Kincaid, On Seeing England for the First Time, HARPER's, Aug. 1991, at 13 (describing England from the point of view of a child growing up in Antigua). 
dual consciousness Bell Hooks had described. ${ }^{43}$ They, and we, and the law, I said, were in need of insights froin the inargin. Those of us in the class would be in differing positions with regard to our ability to gain or share those insights, but all of us could learn, and all of us could learn froin each other.

I invited class inembers to think about the ways they themselves might be positioned in the circle, whether the circle represented their hoinetown, legal education, the courtroom, or western civilization. I asked thein to consider the ways their position(s) might advantage or disadvantage them in their perception of reality and in their ability to communicate to different audiences. ${ }^{44}$ As an illustration of differences in

43. The concept of dual consciousness was explored early from a black male perspective by W.E.B. Du Bois in The Souls of Black Folk, first published in 1903:

Between ine and the other world there is ever an unasked question: unasked by some through feelings of delicacy; by others through the difficulty of rightly framing it. All, nevertheless, flutter round it. They approach me in a half-liesitant sort of way, eye me curiously or compassionately, and then, instead of saying directly, How does it feel to be a problem? they say, I know an excellent colored man in iny town; or, I fought at Mechanicsville; or, Do not these Southern outrages make your blood boil? At these I smile, or am interested, or reduce the boiling to a simmer, as the occasion may require. To the real question, How does it feel to be a problem? I answer seldom a word.

And yet, being a problem is a strange experience,-peculiar even for one who has never been anything else, save perhaps in babyhood and in Europe. . . .

After the Egyptian and Indian, the Greck and Roman, the Teuton and Mongolian, the Negro is a sort of seventh son, born with a veil, and gifted with second-sight in this American world, - a world which yields him no true self-consciousness, but only lets him see himself through the revelation of the other world. It is a peculiar sensation, this double-consciousness, this sense of always looking at one's self through the eyes of others, of measuring one's soul by the tape of a world that looks on in amused contempt and pity. One ever feels his two-ness,-an American, a Negro; two souls, two thoughts, two unreconciled strivings; two warring ideals in one dark body, whose dogged strengtli alone keeps it from being torn asunder.

The history of the American Negro is the history of this strife,-this longing to attain self-conscious manhood, to merge his double self into a better and truer self. In this merging he wishes neither of the older selves to be lost. He would not Africanize America, for America has too much to teach the world and Africa. He would not bleach lis Negro soul in a flood of white Americanism, for lie knows that Negro blood has a message for the world.

W.E.B. Du BoIs, Of Our Spiritual Strivings, in THE Souls of BLACK FolK 1-4 (1953).

Scholars of color continue to explore the pain and strength that accompany this dual consciousness. Charles Lawrence, in listing and describing the special gifts he believes to be part of the African-American heritage, included "the gift of second sight, embracing duality." Charles Lawrence, Remarks at the Meeting of the Law \& Humanities Section of Association of American Law Schools (Jan. 1990) (tape on file with author.) Professor Mari Matsuda recently observed, The multiple consciousness I urge lawyers to attain is not a random ability to see all points of view, but a deliberate choice to see the world from the standpoint of the oppressed. That world is accessible to all of us. . . . We can choose to know the lives of others by reading, studying, listening, and venturing into different places. For lawyers, our pro bono work Inay be the most effective means of acquiring a broader consciousness of oppression.

... Holding on to a multiple consciousness will allow us to operate both within the abstractions of standard jurisprudential discourse, and within the details of our own special knowledge.

Matsuda, supra note 18, at 9 (emphasis in original).

44. None of my talk about privileging the margin should be read as ignoring the inportance of 
perspective from different poimts of the circle, I shared a story from my years in law practice.

My colleagues and I were representing the surviving husband and children of a black woman who had died at hoine of a heart attack shortly after being sent away from the local emergency room with the word that she was merely suffering indigestion. As we prepared for trial, it became my task to work on the issue of damages, a task that can be strangely inoving in a wrongful death suit.

The job in such a case is to prepare to show the jury the deceased person as a whole, vivid, and sorely missed personality, to find people who loved, respected, or admired her, and get them to help tell her story. Prospectivc witnesses in such cases often have been needing an opportumity to speak, to reflect, to weave a memorial, to find meaming, to mourn, and to rage.

The decedent in this case-I will call her Lucille-had been, from what I could tell, a tough, warm, funny woman. She worked one job at a nearby factory as an assembler of machine parts and for most of her adult hife had also worked second, third, and fourth jobs as a domestic in various people's hoines.

My colleagues and I spoke at length with her husband-I will call him Sam-to identify her dounestic employers, searching for the one that could give us the strongest testinnony about Lucille. We needed to show her wage-earning capacity, of course, and we also wanted to provide a gliunpse of Lucille's personality: her strength, dependability, and sense of humor. In addition we thought a regular employer would be an effective and credible person to corroborate a few questions about Lucille's health because her serious diabetes was a risk factor that was an issue in the hability phase of the lawsuit.

We settled on the woman who had employed Lucille the longesttwenty-two years. This woman-Evelyn, I will call her, although she was, of course, "Mrs." to Lucille and Sam and to our law firm as wellhad always given Lucille glowing recommendations. She was the wife of a promment local businessinan, which might well be a plus for us with a small-town jury. Lucille had helped Evelyn raise her children. Sam plied us with details about this family, its circumstances, its usual weekly schedule, the present whereabouts of the children, the fortunes of the husband.

I reached Evelyn by telephone, explamed my errand, and arranged a visit. Later that week I drove up a long white drive to a serene dove-grey home with a screened back porch profuse with ferns and flowering plants. Our conversation began warmly enough. Evelyn did think very

helping all students to become adept at wielding the "tools of the center." Those skills can be empowering and should be shared. 
highly of Lucille. Yes, she was a hard worker, exceptionally dependable and inature in her judgment, and besides that, really like a good friend. Evelyn would leave her children with Lucille, even overnight or longer, without the shightest hesitation. In fact she had often remarked to her husband that Lucille might as well be a white person.

I did not flinch, but continued with my questions. ${ }^{45}$ In a minute, however, we hit a snag. No, Evelyn would not be able to testify about Lucille's multiple jobs. She was unaware that Lucille had other regular jobs, though she knew Lucille occasionally worked for other ladies in town. And no, she could not tell ine anything significant about Lucille's health, really, she had always seemed just fine. Evelyn was surprised to learn of the diabetes. No, she was unaware that Lucille had carried insulin with her for the past eight years and had given herself daily injections.

Lucille had come into this woman's home several times a week, had performed for her the inost intimate tasks imaginable, and yet many of Lucille's inost basic life circumstances were as though they were nonexistent for her. ${ }^{46}$ As it turned out, these blank spots im Evelyn's knowledge of Lucille made no difference anyway because Evelyn had to tell me she would be unable to testify. She was not used to speaking in public and her health was poor, she said. She did not know if her husband would allow her to testify in any event because of the emotional strain of appearing in court.

Evelyn had stuck with me, I told the class, as a reminder of the difference in what the powerful and the powerless know of and about each other. Soinetimes the knowledge differential is a matter of psychology, sociology, or economics as in the case of Lucille and Evelyn. But sometimes it is actually a matter of law.

To talk about ways that law in particular can work to shape our knowledge and ignorance of each other and of important events, we looked at one final illustration, the case of Blyew v. United States. ${ }^{47}$ I began by explaining that the Blyew case arose in Kentucky soon after the end of the Civil War. I noted that we would be examining the Civil War and its aftermath in much greater detail as we proceeded through the course but that for now the students should be aware of a few simple

45. Although I am not going to address the subject of silence in the face of racist statements, it is a topic worth serious examination. See Patricia Williams, The Obliging Shell: An Informal Essay on Formal Equal Opportunity, 87 MicH. L. REV. 2128, 2148-51 (1989) (black female author's pondering of her own silence when she overheard anti-Semitic remarks in conversation of store clerks).

46. Please understand I ain certain Lucille valued her privacy, and I am not suggesting here that the main problem involved in racial subordination (or in domestic service) is a lack of fully reciprocal intimacy. On the relationship between white female employers and black female domestic servants, see generally Judith Rollins, Between WOMEN: DOMESTICS AND Their EMPLoyers (1985).

47. 80 U.S. (13 Wall.) 581 (1872). 
facts. They needed to know that shortly after the end of the war, Congress passed, and the states ratified, the thirteenth amendment, which abohshed slavery, and that Congress had gone on to enact the Civil Rights Act of $1866,{ }^{48}$ which had as its primary purpose the protection of certain rights of citizenship for the recently freed slaves in the former slaveholding states. I explained that a central feature of the statute was its grant of federal court jurisdiction over "all causes, civil and criminal, affecting persons who are denied or cannot enforce in the courts or judicial tribunals of the State or locality where they may be any of the rights secured to them [earlier in the act]."49 Those "rights secured" imcluded rights traditionally protected by the common law such as the riglit "to make and enforce contracts, to sue, be parties, and give evidence, to . . . loold, and convey real and personal property, and to full and equal benefit of all laws and proceedings for the security of person and property."50

I went on to explain to the students that Blyew was a criminal prosecution brought im a federal court in Kentucky pursuant to the Civil Riglits Act of 1866 . Then I let the justices of the Supreme Court give them the facts of the case. First, from Justice Strong for the majority, the class heard:

[The defendants] were indicted . . . for the inurder . . . of a colored woinan named Lucy Armstrong. ... [A]n averment was inade in the first count that the said Lucy Armstrong was a citizen of the Uinted States, having been born therein, and not subject to any foreign power; that Blyew and Kennard (the persons indicted) were white persons, each of thein at the time of the alleged killing and murder above the age of eighteen years; that the said killing and murder, done and committed, as averred, were seen and witnessed by one Richard Foster, and one Laura Foster, citizens of the United States, having been born therein and not subject to any foreign power, ... both of the African race; and that the said Lucy Armstrong, Richard Foster, and Laura Foster were then and there denied the right to testify against the said Blyew and Kennard, or either of them, concerning the said killing and nuurder, in the courts and judicial tribunals of the State of Kentucky, solely on account of their race and color. ${ }^{51}$

The facts related by the majority are a little tantalizing and inysterious. So we went on to Justice Bradley's dissent, our view operning to include more pieces of information:

The evidence in the case demonstrated the fact that the defendants went to the cabin of Jack Foster, a colored inan, in the evening, and, after sitting a while, coolly proceeded to kill the family, and succeeded in kill-

48. The Civil Rights Act of 1866, ch. 31, 14 Stat. 27 (codified at 42 U.S.C. $\$ 1981$ (1988)).

49. Id. ch. $31, \S 3$ (emphasis added).

50. Id. ch. $31, \S 1$ (emphasis added).

51. Blyew, 80 U.S. (13 Wall.) at 583. 
ing Lucy Armstrong, a blind woman over ninety years old, Foster's mother-in-law; also Jack Foster and his wife and their son Richard; two of the children escaped and were witnesses in the cause. One of the defendants was heard to say to the other, a short time previous to the occurrence, that he thought there would soon be another war about the niggers; that when it did coine he intended to go to killing niggers; and he was not sure that he would not begin his work of killing them before the war should actually commence. ${ }^{52}$

There was uneasy silence in the room. I have read these particular passages aloud now to several different groups. Each time I find myself seized by a combination of elation and terror. This is powerful material, such harsh truth about racism here on the page, intruding itself where we do not expect it. It may even be dangerous. ${ }^{53}$ Nevertheless, as I had done before, I kept on, daring to hope that soinething worthwhile would result. At this point in the dialogue iny listeners still did not know the lolding of the case, and it is the holding that has so much to teach us about racism and the law.

Before discussing the Court's holding and examining what it had decided to do about this searing and partial news froin the inargin, however, I first had to explain the inystery of why two eyewitnesses could not testify to a inurder. So I described the pervasive antebelluin rule in slavelolding states that a black person could not offer testimony in a legal proceeding against a white person, a rule evidently still alive in postwar Kentucky. ${ }^{54}$

52. Blyew v. United States, 20 L. Ed. 638, 642 (1872). In the official reporter this information is reworded and presented as part of the statement of facts. See Blyew v. United States, 80 U.S. (13 Wall.) 581,58485 (1872).

53. Each time I, a well-paid white women, get up and flaunt this hurtful language $\mathrm{I}$ wonder what kinds of wounds are reopened or inflicted by this talk of killing niggers. See, e.g., Mari J. Matsuda, Public Response to Racist Speech: Considering the Victim's Story, 87 MicH. L. REv. 2320, 2327 n.41, 2329 \& n.49 (1989) (when discussing hate speech, author refrains from even spelling racial slurs, using instead " $\mathrm{n}-\mathrm{r}$ " and "J-p" to avoid harm to others and to "prevent desensitization to harmful words"). Are these passages vulnerable to sensationalism? In reading them, what kinds of messages do I send about what racism really is?

54. See Robert D. Goldstein, Blyew: Variations on a Jurisdictional Theme, 41 STAN. L. REv. 469, 483-84 (1989). Apparently the particular evidentiary statute in effect in Kentucky at the time of Blyew was actually passed by the Kentucky legislature after the war, in 1865 . See id. at 483. A federal district court in Kentucky had ruled that the state statute was overridden by the Civil Rights Act of 1866 but the Kentucky Supreme Court had ruled the opposite and declared the federal statute unconstitutional. Id. at 484. Thus at the time of the Blyew prosecution, the issue stood contested, and the U.S. Attorney would have known that the testimony of Richard and Laura would be excluded in Kentucky state court by virtue of a relatively recent statute and despite passage of the Civil Rights Act of 1866 . Id.

The effect of this postwar Kentucky law was much like that of the Black Codes of several states, which had provisions so oppressive to black people, so grudging in their definition of freedom, that they are widely credited with creating the impetus for the fourteenth amendment and the end of Andrew Johnson's deferential "Presidential Reconstruction." See RECONSTRUCTION 1865-1877, at 41-42 (Robert W. Johannsen ed. 1970) (quoting the amazing remarks of Benjamin Humphreys, then Governor of Mississippi, suggesting the legal strategy the southern states should devise for handling 
I then asked the class what they would have done had they been federal prosecutors wishing to bring these murderers to justice, faced with a Kentucky statute that would exclude Richard's dying declaration and Laura's eyewitness testimony from a state court trial. All were agreed that they would use the 1866 statute to bring the case im federal court. It looked like a perfect fit. And that is, of course, exactly what the prosecutor did in Blyew.

Then I informed them of the holding. The Supreme Court of the Uinted States held in Blyew that the indictment against the accused murderers should be dismissed because the Civil Rights Act of 1866 did not grant jurisdiction to the federal courts in such a case. ${ }^{55}$ I asked them to miagine, based on what I had already told thein, what explanation the Court could possibly have offered for its denial of jurisdiction under circumstances such as those before it.

After sonie discussion, the class teased out the Court's rationale: the federal court lacked jurisdiction because this case was not one "affecting persons who are ... deined ... in the courts ... of the State ... any of the rights secured to them by [this act]." Certainly "the rights secured" exphicitly included the right to give evidence and the right to equal benefit of laws protecting personal security. ${ }^{57}$ The problen was rather that there were no persons affected within the meaning of the statute. ${ }^{58}$ The "parties" to the case were, after all, ouly the governnient and the alleged murderers! None of those parties clamed to have been denied any rights. Perhaps Lucy and her grandchildren had rights at stake nit some sense, but this case, this prosecution, could not be one "affecting" Lucy Armstrong because she was dead. And Laura and Richard Foster were similarly unaffected in the eyes of the Court because they were inerely witnesses. ${ }^{59}$

the newly freed blacks). For a recent resource on these and other features of the Reconstruction era, SEe ERIC FONER, RECONSTRUCTION: AMERICA'S UNFINISHED REVOLUTION 1863-1877 (1988). For insight into the intense, often sliameful politics of Reconstruction historiography, see Randall Kennedy, Reconstruction and the Politics of Scholarship, 98 YALE L.J. 521 (1989).

55. Blyew, 80 U.S. (13 Wall.) at 591-93.

56. The Civil Riglts Act of 1866, cl. 31, § 3, 14 Stat. 27 (codified at 42 U.S.C. § 1981 (1988)).

57. See supra text accompanying note 50 .

58. Blyew, 80 U.S. (13 Wall.) at 591-93.

59. "Those wlı may possibly be witnesses, either for the prosecution or for the defence, are no more affected by it than is every other person, for any one may be called as a witness." Id. at 591-92. A fedcral district court in Kentucky had already considered this argument and rejected it in United States v. Rhodes, 27 F. Cas. 785 (C.C.D. Ky. 1866) (No. 16,151). The court renarked that "it is by no means true, as a universal proposition, that none are affected in the legal sense of the term, by a case, but those who are parties to the record. The solution of the question must always depend upon the circumstances." Id. at 787.

Goldstein, in his article on Blyew, decried the fact that it "has never been part of the established canon of civil rights texts" and traced its historical treatment by legal scliolars. Goldstein, supra note 54 , at $475 \&$ n.25. (This talk of a canon is, of course, gratifyingly germane in the present context.) He deplored Blyew's relative obscurity and argued that the case represented an important 
The enormity and elegance of this logic seemed to take a while to sink in. The Supreme Court was declaring itself powerless, despite the existence of the Civil Rights Act of 1866, to require that Laura and Richard Foster's voices be heard against the inen who murdered their parents and grandmother before their very eyes, powerless to order that they were entitled to tell their story before the seats of justice. We spoke again of the metaphor of margin and center. We spoke once inore about silencing and exclusion. The resonance of the metaphor with the experiences of Laura and Richard Foster was unmistakable.

After we paused a inoinent, I announced that part of what we would be about in the course was working together on the Lucy Armstrong Memorial Project. The aim of this project would be the telling of Lucy Armstrong's story, the opening up of the arena of American legal discourse to the witness of Laura and Richard and others like them, and a conscious effort to locate and histen to the narratives of those who, like Lucy's grandchildren, like Lucy herself, have too often been silenced and excluded by the rules, procedures, and assumptions under which the nation has attempted to do justice. ${ }^{60}$

milestone in post-Civil War jurisprudence. Id. at 475 . Though it was decided a year earlier, he believes it slould be viewed as a companion case to the Slaughter-House Cases, 83 U.S. (16 Wall.) 36 (1873). Goldstein, supra note 54, at 475 n.25. I found Blyew inyself in the brief historical section introducing Theodore Eisenberg's casebook, CiviL RIGHTS LEGISLATION: CASES AND MATERIALS 12-18 (3d ed. 1991), only discovering Goldstein's well-researched and provocative article after I had taught the class. I agree with that author's estimation of the importance of the case.

60. This conception of the Lucy Armstrong project was greatly influenced by others exploring the narrative inode. See, e.g., Symposium: Legal Storytelling, 87 Mich. L. REV. 2073 (1989).

Robin West lias cast the feminist project as a call to "tell true stories of woinen's lives." Robin West, Jurisprudence and Gender, 55 U. CHI. L. REV. 1, 64 (1988). She urged women to "flood the market witl our own stories until we get one simple point across: inen's narrative story and phenounenological description of law is not women's story and phenomenology of law." Id. at 65; see also Brief for the National Abortion Rights Action League at 5-11, Thomburgh v. American College of Obstetricians and Gynecologists, 476 U.S. 747 (1986) (Nos. 84-495, -1379) (quoting letters from women about their own and others' decisions to have abortions); $c f$. DAvID C. REARDON, ABORTED WOMEN: SILENT No MORE (1987) (containing narratives from women who oppose abortion).

In addition to, and overlapping with, the feminist call for stories, several scholars of color have both advocated and used narrative in various contexts. See Richard Delgado, Storytelling for Oppositionists and Others: A Plea for Narrative, 87 Mich. L. REv. 2411 (1989). Arguing that legal scholars sliould listen to voices "from the bottom," Mari Matsuda featured personal remembrances of Japanese-American internment victims in an article theorizing about reparations. See Matsuda, Looking to the Bottom, supra note 15.

Charles Lawrence and Patricia Williams have been telling their own stories in different ways and with great power. See, e.g., Lawrence, supra note 7 (beginning analysis of doctrine of discrimmatory intent with a story); Pat Williams, On Being Invisible, 4 HARv. BlackLETTER J. 16 (1987); Williams, supra note 45; Patricia Williams, Spirit-Murdering the Messenger: The Discourse of Fingerpointing as the Law's Response to Racism, 42 U. MIAMI L. REV. 127 (1987); Patricia J. Williams, On Being the Object of Property, 14 Signs 5 (1988). Michael Olivas used his grandfather's stories to reflect on a clironicle by Derrick Bell and to frame his own thoughts on race and law in United States history. See Olivas, supra note 22.

Derrick Bell has turned to fable and allegory as tools of persuasion. Further, he has opened up 
Many things happened after that first class: ruptures and connections, highs and lows, clarities and confusions, instances of bravery and instances of cowardice froin the instructor and from others in the class. But the inetaphor of inargin and center, the image of the chalk circle (a drawing I had thought about but had not decided for certain I would even execute until I found inyself at the board that inorning), stayed with us throughout the course. It cropped up repeatedly in student papers, in class discussions, and on the final examination. I think the inetaphor, though filled with ambiguity like inost good metaphors, is a powerful one.

\section{Course Structure}

That first class was desigued to begin a course on race and gender "discrimination,"61 hardly a part of the law school core curriculuin. What it ushered in, however, was a series of texts and questions that I will argue are clearly relevant, often central, to the overall teaching effort in American law schools.

The course was organized into two broad sections. First, we took an extended look at the legal history of race and then of gender in America.

tales of his own professional life in a continuing effort to persuade fellow academics of the reality and urgency of racial problems in the academy and in society. See, e.g., Derrick Bell, Xerces and the Affirmative Action Mystique, 57 GEO. WASH. L. REv. 1595 (1989); Derrick Bell, Racism: A Prophecy for the Year 2000, 42 RUTGERs L. REV. 93 (1989). For examples of Bell's willingness to offer up his own vocational struggles as fables of a different sort, see Derrick Bell, The Final Report: Harvard's Affirmative Action Allegory, 87 Mich. L. REv. 2382 (1989); Derrick Bell, The Price and Pain of Racial Perspective, StaN. L. Sch. J., May 9, 1986, at 5 (describing an incident at Stanford also discussed at length in Roy L. Brooks, Anti-Minority Mindset in the Law School Personnel Process: Toward an Understanding of Racial Mindsets, 5 LAw \& INEQUALITY 1 (1987)). Bell's storytelling has prompted both criticisin (see, e.g., Lino A. Gragha, Book Review, 5 CoNST. CoMmENTARY 436, 437 (1988) ("Bell's book, [And We Are Not Saved,] is a whining hitany of arrant and pernicious nonsense written in childish prose")) and emulation (see Robin D. Barnes, An Extra-Terrestrial Trade Proposition Brings an End to the World As We Know It, 34 ST. Louls U.L.J. 413 (1990); Michael A. Middleton, After We're Gone?: A Commentary, 34 ST. Louis U.L.J. 443 (1990)).

61. I place this word in quotation inarks because its ineaning is so profoundly contested at this point that I would probably not have chosen it as the name of the course had it not already been chosen for me. Some authors have identified antidiscrimmation with a color-blind, individualistic, opportunity-focused value; they contrast it with a color-conscious, group-oriented, results-oriented value. Thus, Randall Kennedy counterposed antidiscrimination with antisubjugation. Randall Kennedy, Persuasion and Distrust: A Comment on the Affirmative Action Debate, 99 HARV. L. REV. 1327, 1336 (1986).

Ruth Colker, on the other hand, described a similar polarity but abstained froin using the word "discrimination" at all. Instead, she dnbbed the two poles as "anti-differentiation" and "antisubordination." Ruth Colker, Anti-Subordination Above All: Sex, Race, and Equal Protection, 61 N.Y.U. L. REv. 1003, 1006-07 (1986).

Two writers have recently insisted that the word (like the whole of "antidiscrimination" law) contains and should continue to contain both meanings: discrimination as differentiation and discrimination as subordination. See Crenshaw, supra note 22, at 1341-46; D. Marvin Jones, Unrightable Wrongs: The Rehnquist Court, Civil Rights, and an Elegy for Dreams, 25 U.S.F. L. REV. 1, 2-3 (1990). 
Next, we examined employment discrimination law (a particular area of contemporary legal doctrine that concerns both race and gender) as a kind of doctrinal case study. We concluded with a look at the present and some speculations about the future.

The fact that I was teaching this course in the fall of 1989 made the subjects of "race and gender in the present" especially loaded ones. That year the Supreme Court had released a volley of cases that shook the then-existing structure of employment discrimination law to its foundations $^{62}$ and had hinted that Roe v. Wade might be overruled or seriously weakened within the next few terms. ${ }^{63}$

I will not argue that extended treatment of employment discrimination is at some easily agreed-upon core of a broad legal hiberal arts education. It is in the area of history, and especially constitutional history, ${ }^{64}$ that I beheve legal educators should be able to reach consensus about the centrality of race to our discipline. The remainder of my reflections on

62. See Lorance v. AT\&T Technologies, Inc., 490 U.S. 900 (1989) (interpreting the statute of limitations to make it more difficult for women to challenge even an intentionally discriminatory seniority scheme); Martin v. Wilks, 490 U.S. 755 (1989) (allowing white fire fighters to ehallenge a consent decrec imposing an affirmative action plan long after it was originally entered); Patterson v. McLean Credit Umon, 491 U.S. 164 (1989) (excluding posthiring racial harassment from harms remediable under $\S 1981$ and treating as highly contestable the statute's ability to reach privatc discrimination); Wards Cove Packing Co. v. Atonio, 490 U.S. 642 (1989) (redefining the nature of a disparate-impact case under Title VII of the Civil Rights Act of 1964 to make it much more difficult for plaintiffs to prove sex or race discrimination in the absence of evidence of discriminatory intent). All of these employment cases were decided in the shadow of the earlier City of Richmond v. J.A. Croson Co., 488 U.S. 469, 472 (1989) (applying strict scrutiny to affirmative action and striking down a mumicipal minority set-aside program). The implications of Croson for employment law, like the larger implications of many of the above cases, are still unclear. See Metro Broadcasting, Inc. v. FCC, 110 S. Ct. 2997 (1990) (upholding a minority preference in federal broadcast licenses). The literature on the 1989 spate of cases is voluminous, deeply divided, and still emerging. See, e.g., Charles J. Cooper, Wards Cove Packing Co. v. Atonio: A Step Toward Eliminating Quotas in the American Workplace, 14 HARV. J.L. \& PUB. POL'Y 84 (1991) (arguing that the plaintiff's ligher burden of proof established in Wards Cove relieves in salutary fashion the pressures on employers to use racial quotas); Alan Freeman, Antidiscrimination Law: The View from 1989, 64 TUL. L. REV. 1407 (1990) (examining evolution of antidiscrimination law since 1954 and exploring its contradictory character); Linda S. Greene, Race in the 21st Century: Equality Through Law?, 64 TuL. L. REv. 1515 (1990) (arguing that the 1989 Supreme Court decisions help effectively disallow legal redress of inequalities); Randall L. Kennedy, Competing Conceptions of "Racial Discrimination": A Response to Cooper and Graglia, 14 HARV. J.L. \& PUB. Pol'y 93 (1991) (examinimg Patterson in light of Cooper's article, supra, and arguing that the disparate-impact approach is better because it reaches other forms of conduct affeeting race relations besides intentional discrimination).

63. See Webster v. Reproductive Health Servs., 492 U.S. 490 (1989) (upholding statutory ban on public assistance of nontherapeutic abortions).

64. For a literary look at ways in which the Constitution is to American law what the canon is to the literary tradition, see Michael T. Gilmore, The Constitution and the Canon, 29 WM. \& MARY L. REv. 35 (1987). If you accept that analogy and will grant the Constitution canonical primacy in the American legal world, then you might say that this Essay is designed to convince you of the paradoxical point that the marginalized are alrcady at the core of our law, awaiting our recognition. 
the discrimmation course will therefore focus on race and the Constitution, broadly considered.

\section{Race and the Constitution}

It hardly needs saying that the Constitution represents contested and bloody ground. There are sharply conflictimg narratives about many facets of this document and specifically about its relationship to race. Law students ought to be familiar with these competing narratives. The celebration of the Constitution's bicenteunial brought on a great flowering of scholarship and commentary about race and the Constitution and sharply focused some of the competing narratives. ${ }^{65}$ No doubt scholars of differing persuasions would have raised the race question during the bicentennial in any event, ${ }^{66}$ but a highly publicized speech by Justice Thurgood Marshall ${ }^{67}$ underscored the question in such a dramatic fashion that it provoked additional contributions and responses. Justice Marshall's primary point was that he could not jom unreservedly in the celebratory mood of the bicentennial:

The focus of this celebration invites a complacent belief that the vision of those who debated and compromised in Philadelphia yielded the "more perfect Union" it is said we now enjoy.

I cannot accept this invitation, for I do not believe that the ineaning

65. See, e.g., Slavery and Its Consequences: The Constitution, Equality, ANd RACE (Robert A. Goldwin \& Art Kaufman eds. 1988) [hereinafter SLAveRY AND ITS CoNSEQUENCES] (part of series entitled "A Decade of the Study of the Constitution"); Ellen C. DuBois, Outgrowing the Compact of the Fathers: Equal Rights, Woman Suffrage, and the United States Constitution, 1820-1878, 74 J. AM. Hist. 836 (1987); Foner, supra note 33; Vincent G. Harding, Wrestling Toward the Dawn: The Afro-American Freedom Movement and the Changing Constitution, 74 J. AM. HIST. 718 (1987) (symposiun entitled "The Constitution and American Life"); We the People: $A$ Celebration of the Bicentennial of the United States Constitution, 30 How. L.J. 915 (1987) (symposium issue); Nathaniel R. Jones, Remarks on the Bicentennial of the U.S. Constitution, 5 HaRv. BlackletTer J. 12 (1988) (symposium issue); Symposium: The Constitution and Race: $A$ Critical Perspective, 5 N.Y.L SCH. J. HuM. RTs. 229 (1988) (reprinting papers froin conference on Race and the Constitution held by National Conference of Black Lawyers); Mark Tushnet, The Politics of Equality in Constitutional Law: The Equal Protection Clause, Dr. Du Bois, and Charles Hamilton Houston, 74 J. AM. HisT. 884 (1987); Walker, supra note 33.

66. See Harry N. Scheiber, Introduction: The Bicentennial and the Rediscovery of Constitutional History, 74 J. AM. HIsT. 667, 673 (1987) (introduction of symposium issue devoted to the Constitution); see also Steve Chapman, $A$ View of the United States Constitution from Urban American Indians, 10 HAMLINE L. REV. 87 (1987) (bicentennial is not a cause for celebration for most Native Americans because most did not receive citizenship rights until 137 years after signing of the Constitution); Gerald P. López, The Idea of a Constitution in the Chicano Tradition, $37 \mathrm{~J}$. LEGAL EDUC. 162 (1987) (from the perspective of Chicanos, "the Constitution ... heralded the tradition of those with whom [Chicanos] regularly fought," id. at 163).

67. The precise event was the Annual Seminar of the San Francisco Patent and Trademark Law Association in Maui, Hawaii, on May 6, 1987. For two among many reprints of Marshall's speech, see Thurgood Marshall, Commentary: Reflections on the Bicentennial of the United States Constitution, 101 HARv. L. REv. 1 (1987) [heremafter Marshall, Reflections on the Bicentennial]; Thurgood Marshall, The Constitution: $A$ Living Document, 30 How. L.J. 915 (1987) (symposium issue celebrating bicentennial). 
of the Constitution was forever "fixed" at the Philadelphia Convention. Nor do I find the wisdom, foresight, and sense of justice exhibited by the framers particularly profound. To the contrary, the government they devised was defective from the start, requiring several amendments, a civil war, and momentous social transformation to attain the system of constitutional government, and its respect for the individual freedoms and human rights, that we hold as fundamental today. ${ }^{68}$

Those in sympathy with Justice Marshall's sentiments rejoiced at his ringing words. ${ }^{69}$ Critics, on the other hand, accused Marshall of "blaming" the founders for "act[img] immorally,"70 of having made a "virulent" attack on the framers. ${ }^{71}$ One author argued that Marshall had "bewilderingly given Dred Scott new life" by accepting the Court's representation of the framers' behiefs and instructed the justice to "give up the effort to revive this foul-smelling corpse."72 The Washington Legal Foundation called for Marshall's resignation because his re1narks dis-

68. Marshall, Reflections on the Bicentennial, supra note 67, at 1-2. Marshall's speech called forth echoes of a similar occasion. In his famous 1852 Independence Day speech, Frederick Douglass proclaimed, "This Fourth of July is yours, not mine. You may rejoice, $I$ must mourn." Fredericx Douglass, The Meaning of July Fourth for the Negro, in 2 ThE LiFe AND WRITINGS of Frederick Douglass: Pre-Civil War Decade 1850-1860, at I81, 189 (Philip S. Foner ed. 1950) [heremafter 2 LIFE AND WrITINGS OF FREDERICK Douglass] (speech at Rochester, New York, July 5, 1852) (emphasis in original).

69. Charles Lawrence recalled, "My mother called that same day and said, 'Did you read what Thurgood said about the constitutional bicentennial? Wasn't it wonderful? That man made my week." " Charles R. Lawrence III Promises to Keep: We Are the Constitution's Framers, 30 How. L.J. 937, 939 (1987). Regina Austin wrote, "It warmed my heart to read an account of Justice Marshall's attack on the offensive narrowness of the celebration of the bicentennial of the Constitution," and observed that as a result of his remarks, "[t]he jubilee proceeded, but with less of the assured self-satisfaction that had characterized it before Justice Marshall spoke out." Regina Austin, "Write On, Brother" and the Revolution Next Time: Justice Marshall's Challenge to Black Scholars, 6 HARv. BlACKLETTER J. 79, 79 (1989); see also Carl T. Rowan, Equality as a Constitutional Concept, 47 MD. L. REv. 10 (1987) (examining controversy surrounding Constitution and discussing Marshall's speech).

70. See Comment, supra note 33 , at 123 .

71. Don Fehrenbacher, author of the 1978 book The Dred Scott Case: Its Significancc in American Law and Politics, chose thus to characterize Justice Marshall's thesis in a bicentennial speech at the University of Tennessee. Address by Don Fehrenbacher, University of Tennessee (Sept. 19, 1988).

72. Erik M. Jeusen, Commentary: The Extraordinary Revival of Dred Scott, 66 WASH. U.L.Q. 1, 2, 10 (1988). Jensen also observed that "[u]ntil recently, we thought [Chief Justice] Taney was dead wrong-certainly wrong morally, but wrong also as a matter of history and of constitutional law." Id. at 1-2 (emphasis added). The presumptions behind the "we" might be interesting to explore. Perhaps something about those people he means to include is suggested in his subsequent refleetion that "some of [the framers'] racial beliefs cause us a great deal of embarrassment." Id. at 2 (emphasis added).

Jensen's primary argument is that Taney's reading of the intent of the drafters as clearly and thoroughly white supremacist was ill-founded because there is strong evidence that the framers were opposed to slavery and thought it was inorally wrong but were unwilling to abolish slavery because of "real needs and real fears." Id. at 4-7. To the extent that he is urging us to reject Taney's flat historiography in Dred Scott, Jensen's point is certainly well taken. Id. at 2. 
played a "deepseated bitterness and dislike that impair his capacity." "73 William Bradford Reynolds, then Assistant Attorney General of the United States, stated that Marshall was "absolutely right to reinind us" of "the most tragic aspects of the American experience" but expressed grave concern that the substance of Marshall's analysis was to consign the original unreconstrncted Constitution "to the dustbin of history."74 In Reynolds' view such a move would itself be tragic because "[n]otwithstanding its very serious flaws, the Constitution in its original form constituted the greatest advance for human liberty in the entire history of mankind, then or smce."75

In retrospect, I think Justice Marshall's speech imght have been the best place for me to open this topic with the class. The controversy over his statement certainly conveys a sense of the lieat and immediacy of the historical questions at issue, a lieat and immediacy that some law students doubt intensely. ${ }^{76}$ But as it happened, and given that the first portion of the course was organized chronologically, I started the students off on readings about the mstitution of slavery itself and the laws related to it. In keeping witlı the Lucy Armstrong Meinorial project, I assigned a number of texts produced by slaves tliemselves. ${ }^{77}$ In addition the class read an assortinent of legal and nonlegal materials on slavery. ${ }^{78}$

73. Ted Gest, Justice Marshall's Minority Report, 102 U.S. NEws \& WoRLD REP., May 18, 1987 , at 12 .

74. William Bradford Reynolds, Another View: Our Magnificent Constitution, 40 VAND. L. REV. 1343, 1345 (1987).

75. Id. at 1346. Randall Kennedy raised an interesting counterpoint to both Marshall's supporters and detractors. He observed that Marshall's speech "provided a necessary critique of the uncritical [bicentennial] celebration." Randall Kennedy, Comment, 47 MD. L. REV. 46, 46 (1987) [hereinafter Kennedy, Comment]. He went on, however, to argue against unambiguous rejection of the founders' Constitution, pointing out that before einancipation and the postwar amendments, soine black abolitionists embraced that very instrument. They became "heroic readers who transformed the Constitution into a platform more hospitable to their needs, a platform far more decent than that created by the antebellum Supreine Court." Id. at 48; see also infra text accoinpanying notes 110-12 (discussing debate among abolitionists as to whether 1787 Constitution was proslavery or antislavery). In both this comment and another sinilar piece Kennedy placed his remarks in the context of allegiance, loyalty, and a decision to seck insider over outsider status. See Kennedy, Comment, supra; Randall Kennedy, Afro-American Faith in the Civil Religion; Or, Yes, I Would Sign the Constitution, 29 WM. \& MARY L. REv. 163 (1987).

76. One vivid, though happily unrepresentative, student comment on the end-of-semester evaluation form: "[W] spent so much time on the history of slavery-who cares, not relevant."

77. See, e.g., Major Problems in AMErican Women's History (Mary B. Norton ed. 1989) [hereinafter Problems In AMERICAN Women's History]; Slave Testimony: Two CENTURIES OF LeTTERS, SPEECHES, INTERVIEWS, AND AUTOBIOGRAPHIES (John W. Blassingame ed. 1977). Though it has not always been so, many other sources are now available. E.g., THE Classic Slave NarRatives (Henry Louis Gates, Jr. ed. 1987).

78. Readings included excerpts from State v. Mann, 13 N.C. (2 Dev.) 263 (1829) (holding that a slave owner was not liable for shooting a slave); EDMUND S. MORGAN, AMERICAN SLAVERY, American Freedom: The Ordeal of Colonial Virginia (1975); SLavery Defended: The VIEWS OF THE OLD SoUTH (Eric L. McKitrick ed. 1963); K. STAMPP, supra note 31; ROBERT S. STAROBIN, INDUSTRIal Slavery IN THE OLd SOUTH (1970). 
After this brief sociolegal introduction to the institution of slavery, we began to explore the drafting of the Constitution with respect to slavery, what one author has called "the witch at the christening."79 We looked first at the Declaration of Independence, a comfortably familiar docuinent, but went on to read about a less well-known episode in the Declaration's history. When Thomas Jefferson first drafted the Declaration of Independence, he included a passage that was highly critical of George III for sanctioning the slave trade. ${ }^{80}$ However, the passage was eventually purged from the document. ${ }^{81}$ I viewed this as a first exercise in learning to think about what is missing from the face of legal doctrines and texts, an exercise in learning to histen for silences, to look for negative spaces, and to dream what might be shaping them. ${ }^{82}$

The Constitution of $1787^{83}$ is a inonument to silence on the slavery question. Although the reahty of eighteenth-century chattel slavery is

79. See William M. Wiecek, The Witch at the Christening: Slavery and the Constitution's Origins, in The Framing and Ratification of the Constitution 167 (Leonard W. Levy \& Dennis J. Mahoney eds. 1987).

80. Jefferson originally proposed to include King George's support of the international slave trade as one inore example of the despotic tendencies and unacceptable practices that justified American rebellion. His draft read:

"He [George III] has waged cruel war against hunian naturc itself, violating it's inost sacred rights of life and liberty in the persons of a distant people who never offended him, captivating and carry[ing] then into slavery in another hemisphere or to incur miserable death in their transportation thither. This piratical warfare, the opprobrium of infidel powers, is the warfare of the Christian king of Great Britain."

A. HigginbothaM, supra note 22, at 381 (emphasis in original); see also JAMES MUNVES, Thomas JEFFERSON AND THE DECLARATION OF INDEPENDENCE 99 (1978) (reprinting proposal included in reconstruction of Declaration of Independence).

81. The passage was deleted after congressional debate, Jefferson's July 2 notes recording: "The clause ... reprobating the euslaving the inhabitants of Africa, was struck out in conplaisance to South Carolina and Georgia .... Our Northern brethren felt a little tender for they had been pretty eonsiderable carriers of [slaves]." See A. HigGINBothAM, supra note 22, at 382; see also Paul Finkelman, The Constitution and the Intentions of the Framers: The Limits of Historical Analysis, 50 U. PrTt. L. Rev. 349, 375-76 (1989) (discussing Jefferson's condemnation of King George III).

82. See supra note 20 (discussing "silences" in literature). Toni Morrison has urged those working in a hiterary context to take up the task of

the examination and re-interpretation of the American canon, the founding nineteenthcentury works, for the "unspeakable things unspoken"; for the ways in which the presence of Afro-Americans has shaped the choices, the language, the structure-the ineaning of so much American literature. A search, in other words, for the ghost in the machine.

$\ldots$...

We can agree, I think, that invisible things are not necessarily "not-there"; that a void inay be empty, but is not a vacuum. In addition, certain absences are so stressed, so ornate, so planned, they call attention to thenuselves; arrest ns with intentionality and purpose, like neighborhoods that are defined by the population held away from them. Looking at the scope of American literature, I can't help thinking that the question should never have been "Why am I, an Afro-American, absent froin it?" It is not a particularly interesting query anyway. The spectacularly interestiug question is "What intellectual feats had to be performed by the author or his critic to erase me from a society seething with my presence, and what effect has that performance had on the work?"

Morrison, supra note 20, at 11-12. The applicability of this observation to the Constitution of 1787 will, I hope, become obvious in just a inonient.

83. U.S. CoNST. arts. I-VIII. 
built into the structure of the Constitution of 1787, the word "slavery" never appears in the document. ${ }^{84}$ It is quite possible for an uninformed twentieth-century reader to scan the entire 1787 Constitution with at least moderate care and never realize that slavery was an issue for the framers, let alone that the Constitution embodied a series of conscious and momentous decisions on the slavery question for the nascent republic. ${ }^{85}$ So our first task was to uncover and decode the slavery provisions of the document. 86

First, we discussed the three-fifths clause, under which "free Persons, including those bound to Service for a Term of Years, and excluding Indians not taxed" were counted for purposes of determining a state's representation in the House of Representatives (and for purposes of apportionment of direct taxes), while only three-fifths of "all other persons" were to be counted. ${ }^{87}$ The other persons were, in that context,

84. Some scholars might take exception to my characterization that slavery was "built into" the Constitution. In fact some would argue forcefully that slavery was taken out of it to the inaximum extent possible. Goldman and Kaufman, for example, state that "[t] he great American paradox is that while slavery and the race problems that followed from it are an integral part of our history, slavery and race discrimination are not part of the fundamental principles of the nationand never have been." SLAVERY AND ITS CONSEQUENCES, supra note 65, at xiii (preface by editors).

The U.S. Supreme Court once had this to say on the subject:

[T] he right to seize and retake fugitive slaves, and the duty to deliver them up, in whatever state of the Umion they may be found ... derive their whole validity and obligation exclusively from the Constitution of the United States . . . . Under the Constitution [that rightl is recognized as an absolute, positive, right and duty, pervading the whole Union.

Prigg v. Pennsylvania, 41 U.S. 916 (16 Pet.) 539, 622-23 (1842).

[A Pennsylvania act criminalizing the seizure of fugitive slaves] purports to punish as a public offence against that state, the very act of seizing and removing a slave by his master, which the Constitution of the United States was designed to justify and uphold.

Id. at 626. See generally Stanley N. Katz, The Strange Birth and Unlikely History of Constitutional Equality, 75 J. AM. HisT. 747 (1988) (noting that the original Constitution failed to guarantee protection of individual equality).

85. In support of this proposition I offer, with some chagrin, iny law school self, a reasonably conscientious student in the 1970 s with probably a greater than average interest in racial inatters. I simply never saw a sign of slavery in all iny readings of the Constitution. Frederick Douglass was, perhaps, prescient in this as in some other matters, when he observed:

Had the Constitution dropped down from the blue overhanging sky, upon a land uncursed by slavery, and without an interpreter, although some difficulty inight have occurred in applying its manifold provisions, yet so cunningly is it framed, that no one would have imagined that it recognized or sanctioned slavery.

Frederick Douglass, The Constitution and Slavery, in 1 The Life and Writings of Frederick Douglass: Early YeARS, 1817-1849, at 363 (Philip S. Foner ed. 1950) [hereinafter 1 LIFE AND WRITINGS OF FREDERICK DOUGLASS].

86. Since teaching the class I have found another source of dissenting views on the Constitution. It is The UNITEd States Constitution: 200 Years of ANTI-Federalist, Abolitionist, Feminist, Muckracking, Progressive, AND Especially Socialist CriticisM (Bertell Ollman \& Jonatlian Birnbaum eds. 1990) which includes, among other things, excerpts from W.E.B. Du Bois' Harvard dissertation, Slavery and the Founding Fathers (originally published as The Suppression of the African Slave Trade to the United States of America (1896)), which gives a detailed and astute report of the relevant debates at the founding Convention.

87. U.S. CONST. art. I, $\S 2$, cl. 3. 
slaves.

This provision inost often appears in contemporary popular rhetoric as proof that slaves were devalued by the Constitution of 1787 because each was counted as only three-fifths of a person-less than a full human being. Though the substance of the rhetorical point is well taken, it is nevertheless the case that the more each slave counted, the better for the perpetuation of slavery. Antislavery forces wanted slaves to count for nothing. Slaves, after all, would not vote or otherwise exercise political power in any case. Therefore, each enslaved African-American who "counted" for anything in this formula simply helped to increase the representation of slaveholding states, in effect increasing the political clout of his or her inaster and tipping the balance of power in the Congress inore toward the proslavery forces.

Second, the slave trade clause forbade Congress to outlaw the slave trade until $1808 .^{88}$ Given the history of the issue, proponents of the trade had reason to fear federal action. ${ }^{89}$ Abohtionist forces had attacked the international slave trade early as one of the most vulnerable components in the then-existing infrastructure of slavery, and this trade was subjected to restrictive regulation in various states, both North and South, from colonial times onward. ${ }^{90}$ Even soine who supported slavery found it possible to condemn the international trade. ${ }^{91}$ The slave trade clause of the Constitution of 1787 ensured the trade continued until 1808, and article $\mathrm{V}$ put any shortening of that guaranteed time beyond all ainendment. ${ }^{92}$

Third, the fugitive slave clause required free states to recoguize escaped slaves as the legal property of their owners and to use their legal

88. Id. $\S 9$, cl. 1. The clause reads: "The Migration or Importation of Such Persons as any of the States now existing shall think proper to admit, shall not be prohibited by the Congress prior to the Year one thousand eight hundred and eight ...." The language may be obscure to the modem ear. In conversations with students I learned that I was not the only one who had believed this clause had something to do with liberal immigration policies.

89. See W.E.B. Du Bois, The Suppression of the African Slave-Trade to the UNITED STATES OF AMERICA, 1638-1870, at 54-58 (1896) (report of debate on the issue at 1787 Constitutional Convention).

90. See generally id.; Daniel P. Mannix, Black Cargoes: A History of the Atlantic SLAVE TRADE, 1518-1865, at 171-90 (1962).

91. In 1820 after a conversation with John C. Calhoun, John Quincy Adams wrote in his diary that slavery "perverts human reason, and rednces men endowed with logical powers to maintain that slavery is sanctioned by the Christian religion, that slaves are happy and contented in their condition ... while at the same time they vent execrations upon the slave trade." Quoted in HERBERT Aptheker, Abolitionism: A Revolutionary Movement 10 (1989). See also David B. Davis, The Problem of Slavery in the Age of Revolution, 1770-1823, at 213 (1975) ("American political history showed that opposition to the slave trade could be combined with a defense of domestic slavery.").

92. U.S. CoNST. art. V ("[N]० Amendment which may be made prior to the Year One thousand eight hundred and eight shall in any Manner affect the first and fourth Clauses in the Ninth Section of the first Article...."). 
apparatus to return such fugitives into bondage. ${ }^{93}$ It was this clause that was eventually to generate inuch of the abohtionist heat preceding the Civil War. ${ }^{94}$

Various other provisions of the 1787 Constitution related directly or indirectly to slavery, ${ }^{95}$ and constitutional scholars have proposed numerous ways to categorize and elucidate them. ${ }^{96}$ Other clauses frequently mentioned include those pertaining to the use of the militia to suppress insurrections, ${ }^{97}$ prohibition on export taxes, ${ }^{98}$ and the requirement that constitutional amendinents could only be proposed by a two-thirds supermajority of Congress or of petitioning states. ${ }^{99}$

In the Discrimination class we looked at all these provisions. After histing and decoding the provisions, however, we were faced with the more difficult task of evaluating and interpreting. What do these provisions mean? Why should anyone care about these arcane and coded inessages now that the thirteenth amendment is the law of the land?

This was the point at which I introduced Thurgood Marshall's bicentennial speech, his act of imterpretation. ${ }^{100}$ As a counterpoint to

93. Id. art. IV, $\S 2$, cl. 2. The clause reads:

A Person charged in any State with Treason, Felony, or other Crime, who shall flee from Justice, and be found in another State, shall on Demand of the executive Authority of the State from which he fled, be delivered up, to be removed to the State having Jurisdiction of the Crime.

94. Possible reading assignments relating to the law of fugitive slavery as well as to the massive social ferment that resulted when fugitive-slave catching brought slavery "home" to the Northmuch as the draft and nightly television brought Vietnam home to Americans in the 1960's and failed to bring Baghdad home in 1991-include: Prigg v. Pennsylvania, 41 U.S. (16 Pet.) 539 (1842) (excerpt supra note 84); R. Cover, supra note 31; FREDERICK DouglasS, Is It Right and Wise to Kill a Kidnapper?, in 2 LIFE AND WRITINGS OF FREDERICK DOUGLASS, supra note 68, at 284-89; PhILIP S. FONER, HISTORY OF BLACK AMERICANS: FROM THE COMPROMISE OF 1850 TO THE END OF THE CIVIL WAR 87-108 (1983) (chapter entitled "Black Resistance to the Fugitive Slave Act of 1850: The Last Phase"); JAmes M. McPherson, BatTle CRY of Freedom: The Civil WAR ERA 78-91 (1988); Larry Gara, The Fugitive Slave Law: A Double Paradox, in THE LAW OF AMERICAN SLAVERY: MAJOR Historical INTERPRETATIONS 232 (Kermit L. Hall ed. 1987).

95. For a summary of provisions, see Comment, supra note 33, at 79-81.

96. See id. at 79 n.37.

97. U.S. CONST. art. I, $\S 8$, cl. 15.

98. Id. §9, cl. 5 (federal); id. $\S 10$, cl. 2 (state).

99. Id. art. v. The significance of this article is also contested. Several critics of Justice Marshall thought his argnment was fatally weakened by its failure to acknowledge this provision for change. See, e.g., Reynolds, supra note 74, at 1349 (amendment process as method of constitutional evolution). But see Raymond T. Diamond, No Call to Glory: Thurgood Marshall's Thesis on the Intent of a Pro-Slavery Constitution, 42 VAND. L. REv. 93, 130 (1989) (arguing that original Constitution precluded freeing the slaves precisely because the amendment process required a supermajority and was therefore inpossible without support by slave states).

100. I paired Marshall's remarks, supra text accompanying note 68, with the eloquent words of Sojourner Truth when she spoke to an antislavery gathering just after touring an area of the Midwest that had been devastated by an invasion of weevils that attacked and destroyed the wheat crop, eating the heart of each kernel and leaving an empty husk behind. She is reported to have told the crowd:

"Children,"... "I talk to God and God talks to me. I go out and talks to God in the fields 
Marshall's analysis I also introduced the observations of Don Fehrenbacher. In Fehrenbacher's view the Constitution of 1787 was a compromise that contained both proslavery and antislavery provisions ${ }^{101}$ but which at bottom "dealt only minimally and peripherally with slavery and was essentially open-ended on the subject."102

We began grappling with our varying and sometimes diametrically opposed reactions to the slavery compromise. In their "reflection papers" 103 students displayed a wide range of opimions and previous

and woods. This morning I was walking out, and I got over the fence. I saw the wheat aholding up its head, looking very big. I go up and take holt of it. You b'lieve it, there was no wheat there. I say, 'God, what is the matter with this wheat?' And He says to me, 'Sojourner, there is a little... [weevil] in itl' Now I hear talkin' about the Constitution and the rights of man. I come up and take hold of this Constitution. It looks mighty big, and I feels for iny rights, but there ain't any there. Then I say, 'God, what ails this Constitution?' He says to me, 'Sojoumer, there is a little [weevil] in it.' "

LERONE BENNETT JR., Before THE MAYFlower: A History of BlaCK AMERICA 182 (6th ed. 1988).

101. Fehrenbacher identified the two major antislavery provisions as (1) the territory clause, which lie believes gave Congress the power to exclude slavery from the territories, and (2) the commerce clause, under which lie believes Congress could regulate or abolisli the slave trade after the slave trade clause expired in 1807. See Don E. Fehrenbacher, Slavery, the Framers, and the Living Constitution, in SLAVERY AND ITS CONSEQUENCES, supra note 65, at 1, 13; see also Walter Berns, Comment, 47 MD. L. Rev. 22 (1987) (arguing that "the Constitution was, to the greatest extent possible, an anti-slavery document," id. at 24).

Fehrenbacler admitted that both these categories "came to suffer from erosion" after the framing. Fehrenbacher, supra, at 13. Though Congress did offieially ban the importation of slaves in 1808, enforcement was chronically lax. Id. Congress failed at all attempts to ban slavery in soutlern territories and was eventnally blocked by the Dred Scott decision from doing so in any territory. Id. Nevertheless, Felırenbacher beheved it a mistake to impute the later "proslavery gloss" to the document of 1787. See id. at 16-17. Fehrenbacher identified as elements of this postframing, postslavery trend a number of developments: the federalizing of slavery in the nation's capital, the active role played by the army and state department on behalf of slave owners, the antiabolitionist policies of the U.S. Post Office, and the proslavery cast of many appointments to high federal office, including, of course, the Supreme Court. Id. at 15-16.

102. Fehrenbaclier, supra note 101 , at 13 . Thougli chattel slavery was hardly peripheral to those in bondage, Fehrenbacher, I presume, was referring to the framers, and he may be right that the issue seemed relatively marginal to them. But see William M. Wiecek, "The Blessings of Liberty": Slavery in the American Constitutional Order, in SLAVERY AND ITS CoNSEQUENCES, supra note 65, at 23 (arguing that slavery was an essential element of America's constitutional order in 1787). Some scholars, such as Edmund Morgan, supra note 78 , would in any event dispute whether slavery was a marginal issue in fact as well as attitude, maintaining that slavery was central to the economy of the colomies and the new nation. For other sources that provide good fodder for a discussion of Marshall's thesis, see sources cited supra notes 69-74.

103. The comments that follow, and most otliers quoted tliroughout the Essay, came to me from "reflection papers" that I began assigning just after the mitial readings on slavery. In sequenced subgroups, class members were to reflect upon prior readings and class discussions, drawing upon their legal knowledge where appropriate but also explicitly upon their personal experience.

This idea came from Derrick Bell. See Derrick Bell, Manual of Supplements and SUGGESTIONS FOR RACE, RACISM AND AMERICAN LAW (2d ed. 1980 \& Supp. 1984) (1989-90). He credited Professor Charles Lawrence with first developing this technique. Derrick Bell, Tracy Higgins \& Sung-Hee Suh, Racial Reflections: Dialogues in the Direction of Liberation, 37 UCLA L. REV. 1037, 1041-42 (1990). Botli of these professors assigned the papers prior to class, which has 


\section{exposure:}

Of the readings that we have done, the ones that have surprised me the most are those that dealt with how the founding fathers dealt with the issue of slavery. I had never thought about how the framers had wrestled with this problem.

I just wanted to say that I have never had a Black professor in the seventeen years of iny continuing education. It was not until this class that the Constitution and its Framers had ever been presented to me as anything but perfect, ingenious, and insightful. I am glad that I now know the Constitution has its flaws ..... I'm shocked that this has never been pointed out to me before. Growing up within the inner circle, and being educated there-it's like a select existence which doesn't want to face the realities of those on the fringe. I feel lucky to be moving, although slowly, outward.

I am a thirty-five year old, white, Anglo-Saxon Protestant. . . . I was born and raised ... in the Northeast. I attended high school with a black population of some $80 \%$. I was a minority. When racial violence strnck Detroit, Newark, and many other cities in the 1960's, it struck niy town as well. I have witnessed first-hand a black person get beaten up solely because he was black, and I have seen white persons get beaten simply because they were white. I know from experience that hatred exists in both white and black nien. I have heard words spoken to the effect that the white nian owes the black man soinething because of a thing called slavery. In response to those words I have always felt that the point was moot. I believed that what happened ... should be forgotten, that it was a dead issue and not relevant in twentieth century America. I think I may have been mistaken.

Unqualified, obtuse praise of the Constitution's framers should cause uneasiness. That seems reasonable. Thurgood Marshall's apparent outrage (especially if it reflects shock on his part at the framers' duality of mindset and purpose) seems less so and is perhaps a bit dismgenuous.

the obvious advantage of ensuring that the reading gets done and enriching the class discussion. On the other hand, assigning the papers after the class discussion allowed students to talk about things that happened in class as well. Professor Bell quoted Professor Lawrence about the use of refiection papers:

The assignunent privileges experience and the forceful articulation of that experience. Each week I am newly impressed by the thoughtfulness of these pieces. I ain struck by their honesty, by the students' willingness to risk making themselves vulnerable, by their bravery in their criticism of my inanifested bias or myopia as well as that of the cases and the authors assigned. The power of these pieces is not just in their usefulness as a method for discovering new insights gained from a diversity of experience and perspective, but in the authority they give to voices of those who [h] ave come to experience themselves as without authority.

D. BELL, supra, at 4 (quoting Charles Lawrence, The Word and the River: Pedagogy as Scholarship as Struggle 18 (Mar. 13, 1989) (unpublished manuscript); see also Cain, supra note 39 (describing use of journals in feminist theory class). 
The seeming (and at times, quite real) hypocrisy of politicians has long been recognized ....

$\ldots$

... The Constitution was an attempt to create a flexible framework for rational government in the context of a world filled with regimes exercismg arbitrary power. ... It imdeed represented the naked self-interest of the white men who drafted and signed it. But it also represented an enlightened self-interest. It allowed for change at a later date and therein lies the "morality" of this or any such document.

In all truthfuhiess, Marshall's speech angered me as I read it. However, I tried to put myself im "his shoes," but it is a viewpoint I have never liad to experience. I never thouglit a July 4th celebration or a celebration for our Constitution would arouse such ill-feelings.

In looking at the issues from sucl a different perspective, I was able to understand why Marsiliall and other blacks may have feelings of frustration and anger while the rest of the country celebrates a document which maintained the oppression the blacks were suffering. However, I felt Marsliall was slightly liarslı . . . .

I would be curious to know low many blacks feel the same as Justice Marshall seems to feel.

I know this probably sounds like "rose colored glasses" stuff, but I truly believe all persons are created equal. And even if the Frainers of the Constitution were not sure who they meant when they used a similar phrase, I am.

In class discussions some students viewed the problem as one of madequate information. The students thought that the framers simply had no way of knowing the evils that would flow from slavery and had not been exposed to our now widely shared modern sensibilities on the subject of racial justice. Derrick Bell's Chronicle of the Constitutional Contradiction ${ }^{104}$ posed a challenge to this view by fantasizing a timetraveling black civil rights advocate, transplanted into the Constitutional Convention and armed with amazonian eloquence and grace (even protected by a bulletproof shield) but unable to alter the basic comproinise, despite her troublimg news from the future. Some students were unsettled by the tone of this chromicle ${ }^{105}$ but few disputed its concrete assess-

104. D. BeLL, supra note 32 , at 26-50.

105. One student described his reaction to the scene in this chronicle where one of the founders fires a gun at Geneva Crenshaw, the heroine, after she announces herself and her mission:

This was an excellent choice for the first few weeks of class; as a whitc male it certainly provided me with a "baptism of fire" concerning the real sense of betrayal by America's founders many modern blacks feel. I am not accustomed to witnessing the founders dealt with in so indelieate a manner. I was initially somewhat shocked by "Geneva's" visceral contempt for the founders; I found the shooting incident, for instance, to border on hysteria, a gratuitous "cheap shot" by a civil rights radical designed simply to evoke high emotion. On refiection, however, I realized that my assessment of the ... 
ment of the probable outcome of such a mission.

Some students focused on economic realities ${ }^{106}$ but drew radically different conclusions. Some expressed the view that the accommodation of slavery was "just economics," and therefore somehow had no real racial or moral dimension, while others thought that the economic motive made the moral dissonance all the more intense.

Some perceived the basic question to be whether the framers, and the document they created, were "good" or "bad." Others were more willing to entertain the idea of an openly ambivalent response. ${ }^{107}$ Questions about the existence, meaning, and discoverability of original intent also became unavoidable as we explored the motives and statements of various founders and studied their debates. ${ }^{108}$ The question of intent and

dialogue simply revealed my own prejudices. My first reaction to the scene was "How dare she treat the founders so" rather than "How dare they treat her so," in the sense that she served to represent the people who the founders were in a deliberate, calculated fashion choosing to leave in subjugation.

A black student reflecting on this same reading had a starkly different reaction:

The strength with which I was able to identify with Geneva Crenshaw's futile words was tremendous. I felt almost as though it was I standing behind the-absolutely necessary-protective shield speaking words of compassion and reason to the Framers and being rebuked with words of cold and calculating self-interest. . . .

To get a true taste of the flavor of racism, without actually bemg a victim, one need look at it from the perspective of the damned. I suppose that Virgil could have told Dante a story about the Inferno, but I'in sure the first hand look he got made a deeper impression. Since we cannot all be the victims of racial discrimination, reading views from the margins will help.

106. By "economic Icalities" here I include both the economic self-interest of many framers who were themselves slaveholders, see Comment, supra note 33, at $91 \mathrm{n} .102$ (giving a head count of slaveowning framers), and the powerful role played by slave labor and the products of slave labor im the economies of northern and southern colonies alike, see, e.g., E. MORGAN, supra note 78, at 293387. Understanding the intersection betwcen race and class is, in my view, one of the niost crucial tasks confronting those concerned about racial justice, as I have argued elsewhere. See Frances $L$. Ansley, Stirring the Ashes: Race, Class and the Future of Civil Rights Scholarship, 74 CORNELL. L. Rev. 993 (1989); see also Manning Marable, Toward a Black Politics: Beyond the Race-Class Dilemma, Nation, Apr. 11, 1981, at 417 (discussing debate over whether race or class is at the heart of the inferior statns of blacks). Many members of the Discrimination class sensed the importance of this connection also, although I fear the syllabus did not do enough to help them grapple with it. One student observed:

The experiences of the 1960's and 1970's should teach us that the elimination of de jure discrinination plays but a minute role in true equality. . . .

...

Before discrimination can be effectively dealt with we must recoguize the true cause. The "haves" don't want the "have nots" to recognize what is truly going on because for years they have effectively played various poor groups off against one another. Poor whites vs. poor blacks; poor blacks vs. poor hispanics, etc.

107. On the notion that people (and legal theory) can tolerate, even thrive on, ambivalence, see Patricia J. Williams, Alchemical Notes: Reconstructing Ideals from Deconstructed Rights, 22 HARV. C.R.-C.L. L. REV. 401 (1987). In discussing the different ways that rights may appear to dominant and subordinate groups, Williams noted: "[I]t really is possible to see things-even the most concrete things-simultaneously yet differently; and ... seeing simultaneously yet differently is more easily done by two people than one; but ... one person can get the hang of it with lots of time and effort." Id. at $410-11$.

108. The next time I teach this material I would consider including readings specifically 
its meaning led us to consider other possible values that might orient and guide us in the process of constitutional interpretation. ${ }^{109}$

After we had immersed ourselves in the tug and pull of these different constitutional visions, I told the class that we were not the first to have disagreed about these matters. We then turned to the heated debate that took place over a hundred years ago among abohtionists as to whether the 1787 Constitution was proslavery or antislavery. The Garrisonian wing of the abohtionist niovement concluded that the Constitution was irretrievably proslavery and should be repudiated, by means of "disunion" if necessary. ${ }^{110}$ Another group preached that the Constitution permitted and even mandated immediate abolition of slavery. ${ }^{111}$ Others, including eventually Frederick Douglass, conceded that the Constitution did not mandate abohtion but argued that there were antislavery features in the constitutional text itself that could provide a basis for antislavery politics and eventual victory within the union. ${ }^{112}$ Then as

addressing the issue of original intent. For strong intentionalist perspectives, see Edwin Meese III, The Moral Foundations of Republican Government, in STILL THE LAW OF THE LAND?: ESSAYS ON Changing InTERPRETATIONS OF THE CONSTITUTION 63, 64 (Joseph S. McNamara \& Lissa Roche eds. 1987) ("[o]ur obligation is to understand the Founders as they understand themselves"); Bruce E. Fein, Comment, 47 MD. L. REV. 196, 197 (1988) ("[c]lear and convincing evidence confirms that the doctrine of original intent is the only legitimate judicial guide for constitutional jurisprudence"). For a recent article deftly attacking the conclusions of one intentionalist on his own terms, see Glenn H. Reynolds, Sex, Lies and Jurisprudence: Robert Bork, Griswold and the Philosophy of Original Understanding, 24 GA. L. REv. 1045 (1990) (showing that Bork's interpretation of the Constitution does not comport with that of the framers, as divined froin founders' era sources Bork hinself endorsed). For a nonintentionalist view of race and the Constitution, see Finkelman, supra note 81 (arguing that an intent analysis is not useful in determining constitutionality because framers had varying intents).

109. My readings were slim, and I believe students could have benefited from an introduction to distinguishable interpretive theories. For a recent thoughtful article, see Robin West, Relativism, Objectivity, and Law (Book Review), 99 YALE L.J. 1473, 1481, 1490 (1990) (specifically addressing slavery and the Constitution).

110. Alleen S. Kraditor, MEANS and Ends in American Abolmtionism: GarRison and His Critics on Strategy AND TACTics, 1834-1850, at 196-97 (1969) (quoting resolution introduced by Garrison to dissolve the union).

111. See William M. Wiecek, The Sources of antislavery Constitutionalism in AMERICA, 1760-1848, at 252-53 (1977) (speech before the American Anti-Slavery Society, May 11, 1847).

112. For a look at Douglass' fascinating transition, see FreDERICK Douglass, The Right to Criticize American Institutions (May 1847), in 1 LIFE AND WRITINGS Frederick DovgLASS, supra note 85, at 234; FREDERICK Douglass, The Constitution and Slavery (Feb. 1849), in 1 LIFE AND WRITINGS OF FREDERICK DouglaSS, supra note 85, at 352 (correspondence with C.H. Chase); FREDERICK Douglass, The Constitution and Slavery (Mar. 1849), in 1 LIFE AND WRITINGS OF Frederick Douglass, supra note 85, at 361; FREDERICK Douglass, Oath to Support the Constitution (Apr. 1850), in 2 LIFE AND WRITINGS OF FREDERICK DougLASS, supra note 68, at 115; FrederICK Douglass, Change of Opinion Announced (May 1851), in 2 LIFE AND WRITINGS of Frederick Douglass, supra note 68, at 155-56; Frederick Douglass, The Dred Scott Decision (1857), in 2 LIFE AND WRITINGS OF FREDERICK Douglass, supra note 68, at 407-24 (speech before American Anti-Slavery Society, May 11, 1857); FRederick DougLASs, The Constitution of the United States: Is It Pro-Slavery or Anti-Slavery? (1860), in 2 LIFE AND WRITINGS OF FREDERICK Douglass, supra note 68 , at $467-80$. 
now, these disagreements about the framers generated much heat because they were seen as relevant to contemporaneous controversies that bitterly divided the public. ${ }^{13}$

As a culmmation of our study of race and the 1787 Constitution we read the Dred Scott opinion, and four students simulated a debate before the U.S. Congress of $1858^{114}$ on the proposition that "[t]his body should[,] and has the legal power to[,] abolish slavery throughout the territory of these United States of America."115 The exercise had two helpful features. First, it showed students how questions of constitutional interpretation are often cast by those immediately concerned as issues of decisional freedom and constraint wholly separate from morality or politics, though hindsight may cast much doubt on such a characterization. Second, it positioned us to appreciate more fully the events surrounding emancipation and the postwar amendments, which were to be the next major subject on our agenda. Most of the class agreed that at least the appearance of severe constitutional constraint facing the Congress in 1858 must have been formidable nideed. ${ }^{116}$

At this juncture we found ourselves poised at emancipation, the Civil War, and the great postwar clianges in the Constitution. We looked at the birth of the thirteenth, fourteenth, and fifteenth amendments ${ }^{117}$ and the civil rights legislation enacted by Reconstruction congresses (encountering the Blyew case now in a richer context ${ }^{118}$ ). We saw the end of Reconstruction with the Compromise of 1877 and watched the

113. An example of such heat in our own day is the fierce historical debate about the original intent of the framers of the fourteenth amendment and different versions of the postwar civil rights statutes that accoinpanied the Court's deliberations in Patterson v. McLean Credit Union, 491 U.S. 164 (1989). In Patterson issues of great contemporary unoment were cast as turning decisively on the beliefs, goals, and attitudes of the framers of the fourteenth aunendment. In a similar acknowledgennent of the significance of history, the American Enterprise Institute chose to investigate the 1787 slavery compromise in part as a contribution to the debate on affirmative action. SLAVERY AND ITS CONSEQUENCES, supra note 65 , at $\mathrm{xv}$.

114. A moment chosen because it was post-Dred Scott and presecession.

115. Derrick Bell suggested this exercise. See D. BeLL, supra note 103. Varying the class format with exercises of this kind in my view has a salutary effect on the tone of the class and on student engagement.

116. Cf. Anthony J. Sebok, Judging the Fugitive Slave Acts, 100 Y ALE L.J. 1835 (1991) (arguing that pre-Civil War judges were not as constramed as they and later commentators have supposed).

117. Our examination included a look at failed attempts by feminists to have the guarantees of the fifteenth amendment extended to women. Resources concerning this early chapter in the troubled relations between American femirist movements and American antiracist moveunents includc Dubois, supra note 65. For a discussion of racism among white wolnen suffragists, see Rosalyn Terborg-Penn, Discontented Black Feminists, in Problems 1N AMER1caN Women's H15TORY, supra note 77, at 341; Barbara A. Babcock, Clara Shortridge Foltz: Constitution-Maker, 66 IND. L.J. 849 (1991) (recounting alliance of early California femimists with Workingmen's Party of California, which ineant "complicity for [wolnen] in a peculiarly extreme version of anti-Clinese racism," id. at 909). See generally ANGela Y. DAVIs, WOMEN, RAce \& Class (1981); Frederick Douglass on Women's Rights (Philip S. Foner ed. 1976).

118. See supra text accompanying notes $47-60$. 
Supreme Court usher in an era of "long sleep" for the postwar statutes and amendments. ${ }^{119}$ We watched as Brown v. Board of Education ${ }^{120}$ and the civil rights movement brought in the Second Reconstruction. ${ }^{121}$

119. For helpful materials on Reconstruction, see United States v. Harris, 106 U.S. 629 (1883); The Civil Rights Cases, 109 U.S. 3 (1883); United States v. Cruikshank, 92 U.S. 542 (1876); United States v. Reese, 92 U.S. 214 (1876); CONGRESSIONAL COMMitTEE ON RECONSTRUCTION, Testimony TAKen bY the Joint Select Committee to INQuiRe into the Condition of AFFAIRS IN THE LATE INSURRECTIONARY STATES (1872); D. BELL, supra note 22, at 30-38; BLACK RECONSTRUCTIONISTS (Emma L. Thornbrough ed. 1972); FREDERICK Douglass, The Civil Rights Cases, in 4 The Life and Writings of Frederick Douglass 392 (Philip S. Foner ed. 1950) (speech at the Civil Rights Mass-Mecting on Oct. 22, 1883); E. FonER, supra note 54; Foner, supra note 33; Kennedy, supra note 54.

For resourees on the post-Reconstruction period, sometimes called "the nadir," see Berea College v. Kentucky, 211 U.S. 45 (1908); Plessy v. Ferguson, 163 U.S. 537 (1896); JESSIE D. AMES, The Changing Character of LyNChing: Review of LyNCHing, 1931-1941 (1942); Michal

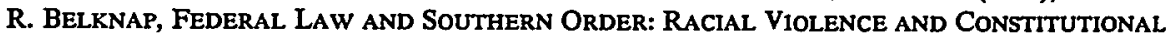
CONFLICT IN THE POST-BROWN SOUTH 1-26 (1987); W.E.B. DU BoIS, supra note 43; ROBERT L. ZANGRANDO, THE NAACP CRUSADE AGAiNst LYNChING, 1909-1950 (1980); E. M. Beck, James L. Massey \& Stewart E. Tolnay, The Gallows, the Mob, and the Vote: Lethal Sanctioning of Blacks in North Carolina and Georgia, 1882 to 1930, 23 LAw \& Soc'Y REv. 317 (1989); William Cohen, Negro Involuntary Servitude in the South, 1865-1940: A Preliminary Analysis, in RACE RELATIONS AND THE LAW IN AMERICAN HistoRy 29-60 (Kermit L. Hall ed. 1987); Randall Kennedy, Race Relations Law and the Tradition of Celebration: The Case of Professor Schmidt, 86 CoLUM. L. REV. 1622 (1986).

One can also find materials about race in particular localities. I was able to find interesting Inaterial about the "nadir" in iny own town in a regional publication. See, e.g., John Egerton, $A$ Case of Prejudice: Maurice Mays and the Knoxville Race Riot of 1919, SOUTHERN ExposURE, July/ Aug. 1983, at 56.

120. 349 U.S. 294 (1955) ("Brown II"); 347 U.S. 483 (1954) ("Brown I"). In conjunction with Brown we read excerpts from two articles describing the black community's reaction to Brown. See Mary L. Dudziak, Desegregation as a Cold War Imperative, 41 STAN. L. Rev. 61, 61-66, 117-20 (1988); Alan Freeman, Racism, Rights and the Quest for Equality of Opportunity: A Critical Legal Essay, 23 HARV. C.R.-C.L. L. REV. 295, 309 n.36 (1988).

121. For resources that discuss the transition to the Second Reconstruction, see Richard KLUGer, Simple Justice: THe History of BROWN v. BOARD of EDUCATION AND Black AmericA's Struggle for EQUality (1975); Howard SITKOFF, A New DEAl for Blacks: The Emergence of Civil Rights as a National Issue: Volume I: The Depression Decade (1978); Mark V. Tushnet, The NAACP'S Legal Strategy Against Segregated EDUCATION, 1925-1950 (1987).

For an important caveat about prevailing ways of demarking significant sources of and periods in the development of the civil rights movement, see Robert Korstad \& Nelson Lichtenstein, Opportunities Found and Lost: Labor, Radicals, and the Early Civil Rights Movement, 75 J. AM. HIST. 786 (1988).

One of the inain goals here was to expose students to the multidirectional relationship between popular movements and legal change. For contrasting explorations of this theme, see Cook, supra note 22 (discussing how King mobilized people into organizations and movements and examining King's use of theoretical deconstruction); Robert J. Glennon, The Role of Law in the Civil Rights Movement: The Montgomery Bus Boycott, 1955-1957, 9 LAW \& HisT. REv. 59 (1991) (arguing that legal decisions and not popular moveinents were the dominant causal factors in desegregation); Randall Kennedy, Martin Luther King's Constitution: A Legal History of the Montgomery Bus Boycott, 98 YALE L.J. 999 (1989) (taking the position that law and legal moves have been underrated by some who stress the efficacy of popular mobilization); Williams, supra note 107 (stressing the transformative role that can be played by movements of the poor and oppressed in defining legal rights). 
The most important and meaningful assignment I gave on the Second Reconstruction was requiring that the class view the entire sixsegment documentary series Eyes on the Prize, Part I. ${ }^{122}$ Student responses to the series were strong and overwhelmingly positive. ${ }^{123}$ One student said:

Every time I had previously studied the civil rights movement in undergraduate and graduate school, it had been by reading a textbook, and the information was strictly from a policymaker perspective. The written page can never convey the emotions of the individual struggling for equahity. Eyes on the Prize showed not only the "leaders" of the inovement, but the marchers, students, lousewives, and children that fought for equality. ... I found myself feeling despair, grief, and hopelessness. I also felt their triumph, strength and joy. In retrospect, it makes me realize how superficial a study of the civil rights movement is without looking into the emotions, the faces, and the lives of the people behind the "leaders" of the movement.

122. Eyes on the Prize, Part I (PBS television broadcast, 1987) (produced by Blackside, Inc.). We scheduled group viewings at the university's audiovisual center; I cancelled two classes during the weeks the viewings took place to indicate that the assignment was serious and that $I$ recognized the time coinmitment involved. Students who could not attend cvening viewings could check out videos from the public library and watch them at home.

Presently, Part II of the series is also available. The second part of the series, like the latter days of the civil rights movement, raises issues inuch inore divisive for a broader spectrun of Americans than the first. These programs explore the reeinergence in the late 1960 s of a long-standing conflict between nationalisin and integrationism in the black cominunity. They probe difficult conflicts among different leaders and groups within the civil rights coalition.

How I would handle the sheer bulk of naterial now available in this series, I do not know. But asking students to encounter the ideas and history of black nationalism is, I behieve, extremely important. After a period of inarginalization, the varying ideas associated with different strands of black nationalism are once again gaining visibility, attracting sizable numbers of followers, and garnering some scholarly attention. See generally Harold Cruse, Plural But EQUal: A CRITICAL Study OF BlaCkS ANd Minorities in AMERICA's Plural SocieTy (1987) (exainining historical roots of the inodern civil rights inovement); James S. Bowen, Law, Legitimacy and Black Revolution: Toward a Theoretical Understanding of Contemporary Black Student Protest and Its Legacy for Modern America, 1 YALE J.L. \& LIBERATION 83 (1989) (reviewing black student protest inoveinents in the 1960 s and relating thein to more recent, though less frequent, black student unrest); David Hall, Paths to Equality: A Constitutional Theory of Collective Rights, 5 HARv. BlACKLETTER J. 27 (1988) (examining Civil Rights inoveınent and Black Nationalist inovement); Peller, supra note 8 (discussing nationalisin in the context of the reappearance and refinement of race consciousness in critical race scholarship); Michele Collison, 'Fight the Power': Rap Music Pounds Out a New Anthem for Many Black Students, CHRON. Higher Educ., Feb. 14, 1990, at A1 (diseussing the current inoveinent toward increased cultural solidarity among black college students and the conflict between black nationalists and integrationists).

123. However, one student did have a criticism that had some bite. It refiected the troubled issue of regional identity that alınost always plays a role in discussions of race among white students in the South:

The only criticisin of Eyes on the Prize that I would express is the lack of any sympathetic Southern white people. Granted, there may have been few such people to focus on, but soineone like Richunond Flowers would have been a good example. I think the filin unfairly portrays all Southern whites as belonging to the extreinist, racist class. 
After watching Eyes on the Prize, as a white person I found myself ashamed of my race. . . . I found myself trying to understand what instilled such hate ... . I found myself questioning how I would have felt and acted, if $I$ had been an adult during the civil rights movement. . . .

These are difficult questions that haunted me while watching the film. I hope that I would have been one of the people that would have marched and worked to break the racist system.

Another remarked:

The old adage "a picture is worth a thousand words" certainly gets at my thoughts on Eyes on the Prize. I have had at least some awareness of the Civil Rights struggle for most of my life but the old film footage brought the movement imto focus in a way that words could never do. The film wreaked havoc on my emotions, which is uncommon for a jaded law student. Eyes on the Prize should be required viewimg in every high school im America.

Going on to study the origins of the fourteenth amendment, its fate during and after Reconstruction and into the present, was just as gripping, troubling, and enlightening as the study of the slavery compromise, and the available materials were similarly rich and filled with controversy. ${ }^{124}$ Nevertheless, instead of contimuing to talk about the topics, readings, and discussions of the "aboveground" part of the discrimination class, I want now to change focus.

\section{The Underground Classroom}

As we read through the materials, ${ }^{125}$ discussed the issues, and conducted the simulations, new reahities unfolded. A law school classrooin, like any classroom, is a multilayered experience. Dynamics of boredom, curiosity, fear, intimidation, and delight all mingle and intertwine and are all mediated by race, class, gender, rehion, sexual orientation, geog-

124. For differing opinions on the significance of Reconstruction to the Constitution, see Herman Belz, Comment, 47 MD. L. REv. 28 (1987) (arguing that the framers of the postwar amendments did not nuake a "new constitution. Rather, they confirmed, clarified and extended the principles . . . embodied in the original Constitution."); M.E. Bradford, "Changed Only a Little": The Reconstruction Amendments and the Nomocratic Constitution of 1787, 24 WAKE Forest L. REv. 573 (1989) (arguing that the Reconstruction amendnents did not significantly change the Constitution); Fein, supra note 108, at 196 (observing that "our Constitution was repcatedly defiled by the radical Reconstruction Congresses because of attorney indifference to constitutional principles"); Arthur Kinoy, The Constitutional Right of Negro Freedom, 21 RUTGERS L. REV. 387 (1967) (arguing for the postenancipation relevance and racial specificity of the thirteenth amendment); Wiecek, supra note 102, at 23, 40 (describing the values of black freedom and equality during the Reconstruction and the present as a "revolutionary change in the original constitutional system").

125. I guess I owe readers the information that inany of my students regularly complained of too much reading. I have concluded that I am simply too green to evaluate the merits of these clainis. (I have no doubt of their sincerity, but that is a separate nuatter.) 
raphy, and other factors. ${ }^{126}$ But I found the subject matter of race as a curricular focus produced tensions well beyond those we all know and recognize as part of the normal course of legal education.

Containing, loosening, respecting, and not being cowed or consumed by these dynamics turned out to be a strenuous assignment. There were tearful office conferences, hallway meetings, some overlapping and some utterly separate grapevines, hurt feelings, outrageously insensitive remarks, suspicion and distrust, and, yes, some real breakthroughs from all directions.

Certainly some of the tensions arose because the course was methodologically different froin the law school norm. ${ }^{127}$ But most of the tension was, I beheve, a result of the fact that we were a racially mixed group trying, at least during large segments of the course, to take a hard, direct look at the subject of race in the United States in 1989. That was a harrowing thing to do, even in tame and sheltered three-times-a-week doses.

I did a lot of things I should not have done in relation to these classroon dynamics and failed to do soine very simple things I should have done. I also discovered some things that seemed to help. I will recount both soine of the mistakes and some of the successes.

On several occasions, rather than risk sounding patronizing, I failed to fill in necessary context for my declarations. I mistakenly assumed that the students wonld read subtlety, sophistication, and nuance into my pronouncements. ${ }^{128}$ One such fumble came during the second day of class when I told the students that I had a "truth-in-teaching" announcement, a sort of fair warning to give thein. I explamed that I almost involuntarily devalue a comment that is prefaced with "I am not a racist, but ..." or "I am not a sexist, but ...." I told the class that upon hearing those particnlar introductory phrases I tend to conclude that the speaker has not yet thought very hard about racism or sexism because it seems clear to me that none of us is beyond or above the wounds, disabilities, and creeping assumptions rooted in the social categories of race and gender. I explained that in my view we are all racists and sexists to one degree or another, although each of us deals with that fact differently. I said that while I beheve the ways individuals choose to deal with this

126. Student comments throughout the semester provided glimpses of the unspoken dynamics of the classroom, as will appear more fully below.

127. Much of the course was entirely traditional, of course, but some of it was noticeably different from what the students were accustomed to encountering. The stress on history, the inclusion of nonlegal materials, my own disclosures of partisanship, were, I think, disorienting for many class members. Some experienced the disorientation as an unexpected pleasure and challenge; others decidedly did not.

128. When one develops some stake in the notion that one is, after all, a subtle, sophisticated, nuanced person, these lapses secm to happen. Beware. 
reality makes a difference, escape or immunity is not an available alternative.

I learned that there was a major gap between what I thought I had said and what the class heard when students later responded in a series of reflection papers. ${ }^{129}$ One student asked:

Am I a racist, a bigot, totally unaware of my true feelings or am I a fairminded person who evidently sees things somewhat different from the majority of my classmates, or at least of the ones that make their feelings known?

Another student remarked:

"I'm not a racist, but ...."

"I'm not a sexist, but ...."

... These reflections center, for the most part, around the power of words. The need to deny one's status as a racist or sexist would seem prima facie evidence of the negative power that has come to be associated with those words.

My attitude toward such power being imvested in inanimate symbols runs a gamut from a primordial fear of the shaman pronouncing syllables laden with magical power to the disgust expressed by Eliza Doolittle in My Fair Lady_ "Words, words, words. I'm so sick of words . . Show me now."

... I admit to feeling a certain (perhaps perverse?) desire to appropriate the labels "sexist" and "racist" to show that ... "words can never hurt me" as the child shouts at his tormentors. It is the "sticks and stones" often attendant to racial . . . mcidents that worry me far more than the labels that anyone can fling at another!

But, of course, words can hurt terribly. ${ }^{130}$ Another student voiced the

129. For an explanation of reflection papers in this class, see supra note 103.

130. See Richard Delgado, Words That Wound: A Tort Action for Racial Insults, Epithets, and Name-Calling, 17 HARv. C.R.-C.L. L. REv. 133 (1982) (independent tort action for racial insults is both permissible and necessary); Matsuda, supra note 53 (victim's response to racist speech and the impact of that speech on target groups). The word "racist" in our culture carries a special charge of its own, importantly different from that of a racial epithet but powerful, nonetheless, as my student so eloquently pointed out. In the creation and packaging of the controversy about "political correctness" that has erupted since I taught this class, much has been made of the hurt that can accompany accusations of racism. For a particularly inflated and lurid example of this discourse, see John Taylor, Are You Politically Carrect?, NEw YoRK, Jan. 21, 1991, at 32 (portraying professor as a victim after black students allegedly accused him of being a racist). For a critiquc of Taylor's article, see Jon Wiener, What Happened at Harvard, NATION, Sept. 30, 1991, at 384 (arguing that the greatest offeuse came not from the students).

Argument by name-calling, even when the argument is sinccre and deeply felt, is highly problematic. The use of freighted terms like "racist," when used to label another individual in a classroom setting, is almost never conducive to intellectual exchange. It blocks rather than promotes communication, and it fosters sloppy thinking and sloppy feeling. Our classrooms should be places where discussion does not proceed by epithet.

One of the most memorable teaching moments I have witnessed was an occasion when Derrick Bell enforced a rule in his class agamst argument by name-calling. "We will not call each other 


\section{following complaint:}

Is it possible to hold conservative views on issues involving race and not be viewed as a "racist"? To many people in our society today, the answer to that question is "NO". If a person does not support set-aside programs for minorities and affirmative action, and lets this position become publicly known, he or she is often branded . . . a racist.

I guess you could say I had touched a nerve! I had intended to touch a nerve, of course, and hiving with some raw edges and some real disagreements is part of the deal. In retrospect, however, I think I should have been more aware of two things. First, I should not presume that class members will be predisposed or well equipped to supply lots of nuanced context for my remarks. Why should they be? ${ }^{131}$ Second, it is important for a teacher in this situation to make some explicit assurances

racists in this class," he said immediately on the heels of a heated remark. I was struck at the time with several things: his clarity and calm about the rightness of the rule, his firmness in articulating it, his demonstrable personal concern for both the person using the epithet and the target of the remark, and the authority he naturally drew from his own strong and visible record on matters of racial justice.

I applaud the judgment of that teacher in that setting to deelare that certain forms of discourse were "off limits" in his classroom. All teachers set such limits, though in most instances they are unconscious and unexamined. After all, law students on the whole are seldom imterested in pushing educational boundaries and are well-enough versed in the law school culture in which they are trying to succeed that they rarely behave in ways that bring to the surface the imphicit boundaries of their teachers. However, the least reflection will surely reveal that such tacit limits exist.

As racial controversies have begun to grow more heated over the last decade and as some whites have begun to give stronger voice to a sense of entitlement wrongly thwarted, both explicit and encoded messages of racial hostility have increased in university settings. Further, as racial newcomers enter predominantly white institutions and classrooms they have begun to tell us about the hurtful effeets of certain words in certain contexts. Both of these developments have called imto question just what the existing implicit boumdaries are and what they should be. I believe that reports of the harmful effects of language should be taken seriously, whether those reports come from meinbers of dourinant groups who are experiencing the pain of being newly cliallenged or from members of subordinate groups who fecl the sting of old stereotypes, long-standing attitudes, or presently unexamined assumptions. The ongoing process of defining and redefining our official and unofficial boundaries in these matters will be difficult and value-laden, of course. In my own experience, the boundaries I and my students seem to find acceptable often change over the course of a semester. The higher the level of trust and mutual respect that has been established in a class, tlie wider the unofficial boundaries become.

131. Eventually I tried again to explain myself by circulating a memo to the class. After I shared some of the student comments with the class and thanked those students for their candor, I went on to say:

When I say (and I do) that "we are all racists," I probably mean something more subtle or modulated (perhaps harder to deal with) than many perfectly reasonable people miglit assume at first learing. I do not mean, for mstance, that we are all necessarily bigoted in any stereotypical or obvious way. I do not mean that we are all so stupid or blind that we are "totally unaware" of our "true feelings," or that we are necessarily ill-intentioned or possessed by gross stereotypes. . . . What I mean is different, though it is now readily apparent to me low I might have sounded otherwise in class.

What I mean about us all being racists has more to do with the notion that I don't think any of us can, in this world, be "free" of race, or "rise above" it, or somehow purge ourselves of it. Surely we can have experiences of transcendence, sparks and even streams of connection across these old scarred battlefields, that can give us real tastes of what 
of safety in addition to warning of danger. ${ }^{132}$ Students have no basis for trusting the teacher at the beginning of class and the teacher should not expect thein to. Besides, what I was asking thein to do-open themselves to a frank but mutually sensitive discussion of race-related inatters in a racially mixed setting-is soinething few of us, students or teachers, have

another way can and might be. But on some very real level we cannot once and for all shed the past and start with a "clcan slate."

Most of us, at least after early childhood, and sooner for most blacks than for most whites, have and bear in our minds and bodies some tension over race. . . Race and racism are not matters we can discuss lightly like the weather, no matter how much we wish we could. Like (but not the same as) the subject of sex and sexuality, this subject of race taps into fears, hopes, emotions, wounds, values, resentments, memories, that color and limit our perception ....

Of course, that should come as no surprise. We live in a society where race has played such a powerful role over the years, and where the question of future agendas is still explosive. Tremendous and increasing disparities continue to exist, side-by-side with increasing opportunities for some, and increasing controversy over how to distribute these opportunities.

I am still struggling with the advisability of my initial "we-are-all-racists" strategy. Threading through so many of our efforts to define and combat racism is the tension between the notion of racism as a crime (a matter of intent and fault) and racism as a disease (a disease that has impact on subordinate groups, that is institutionalized in our society, and that affects all of us in ways we certainly do not have to imtend and may not even be able to bring to consciousness). (This distinction tends, of course, to be less salient and significant for those who are on the receiving end of racial disparities than for those who are not.)

I behieve we now have strong (certainly not unanimous) public consensus that the "crime" version of racism is a bad thing, enough so that the word "racist" will immediately be perceived by the vast majority of listeners as an accusation and an insult. We do not have such strong public consensus that the disease of racism is an evil of which the law (or much else) should take cognizance. Some of us, myself included, believe it is of utmost importance that this kind of racism-the system of de facto white supremacy-be exposed, studied, and ended. But I do not believe the average white person will understand the word "racist" to be referring to this type of racism.

In class, and in my memo, I was, of course, attempting to explain that I was referring in large part to the "other" kind of racism. I have begun to ask myself whether I have been opportunist in my approach. It seeins to me that I may lave wanted to plug into the einotive and majoritarian power of the widespread public sentiment that rejects the crime of racism, all the while busily denying that I was making any reference to it. If so, I may not have been fighting fair. I believe that the two kinds of racism are both openly and subterraneanly connected in ways that whites especially need to face and understand. They are mutually reinforcing. But it may be that $I$ need to find cleaner ways of recognizing that two different meanings are likely to be at work.

In any event there is, unfortunately, still more than enough racism of both varieties to go around and to affect our classrooms deeply. And the widespread compulsion by some people to deny any racism on their own part calls for some exanination. When a crowd of jeering white demonstrators stands on the sidewalk in Bensonliurst to protest black demonstrators and holds aloft two emblems-one a sign proclaiming "WE ARE NOT RACISTS" and the other a watermelonthen more on the term "racism" remains to be said. Most students of color will have such images indelibly imprimted in their memories and that will, and should, affect the way they respond to assertions by whites that they are not racist.

132. As opposed to my tactic of labeling everyone, some authors suggest careful thought and planning so as to label no one. See Mary J. Eyster, Analysis of Sexism in Legal Practice: A Clinical Approach, 38 J. Legal Educ. 183, $185 \mathrm{n.7}$ (1988) (noting that the terms "feminist" and "feminism" may lave negative connotations); Suellyn Scarnecchia, Gender \& Race Bias Against Lawyers: A Classroom Response, 23 U. MICH. J.L. REF. 319, 322-23 (1990) (describing teaching methodology that allowed students to engage in frank discussions with little fear of being labeled racist or sexist). 
achieved or experienced in this culture inore than fleetingly, if at all. ${ }^{133}$ Assuming unreasonable amounts of help, context-setting, and nondefensiveness froin my audience, then, was one fumble that triggered static im the underground classroom.

My response to static that was already present, either in reality or im iny imagination, was another type of fumble. In too many instances I allowed myself to be counterproductively concerned that some students would perceive me as biased in favor of others. Of course some of them would, and did. One student observed in the anonymous end-of-the-year evaluations:

I am sure she doesn't realize it, but she favors "people of color" and their comments-for instance, more than once a white student and a black student have said the same thing $A N D$ the white student was criticized and the black student praised.

Allegations of teacher favoritism are serious business to me. But I beheve my job was to be as fair as I could figure out how to be-a complicated proposition in itself-and to avoid feeling intimidated by fears of backlash from different quarters. If teachers intend to open this scary space, they need to be ready to make it reasonably safe and bearable for all inembers of the enterprise and be willing to take a few lumps in the process. It was not a comfortable feeling when some students came to me privately to express their fears of the reaction I might provoke against myself and against other students if I expressed too many "pro-black" or "pro-woman" sentiments. Nor was it comfortable for me to contemplate my own tendency to worry so much about the feelings of students in a dominant group when they were being challenged by those in a subordinate group. ${ }^{134}$ But teacher comfort-maintenance is hardly an educational objective worth einbracing.

Some flavor of the varying pushes and pulls will perhaps come

133. At any rate, for those of us who are white, who feel discomfort when the subject of racism comes up, it is important to listen before we defend and to imagine the costs imposed on a thoughtful speaker (especially a speaker of color) who ventures to give uncomfortable feedback. Perhaps with some work, we can model this kind of behavior for our students. See Angela P. Harris, On Doing the Right Thing: Education Work in the Academy, 15 VT. L. REV. 125 (1990) (encouraging minority faculty in majority institutions to challenge racism in private as well as in public and explaining for readers of all colors how this process can feel for the challenger).

134. I knew from experience that such concern on the part of a teacher can lead to burdening inappropriately those from the subordinate group who are already burdened more than enough and who should not be asked to center their classroom efforts on sensitivity to others. Certainly all class members can and should be asked to treat each other with respect. But teachers should be careful to note their own identifications: whose pain is easiest for us to understand, and therefore whose sensitivities do we take most care to respect? Whose learning path is most like our own, and therefore which path are we most likely to work to keep brush free? In my own case I believe my background makes me especially quick to notice the pain of whites who are being subjected to varying forms of racial challenge. I hope, of course, that I can put that characteristic of mine to good use. I also believe, however, that I necd to be aware of its biases and dangers so that I can also be a good, fair, supportive, and challenging teacher for the other students in my classes. 
through in the following anonyınous comments from midstream student evaluations:

This has been one of the very few classes here that has stimulated independent thinking for me.

The class was simply a forum for blacks to vent their anger. White students' comments were passed over many times ... or countered angrily or laughingly by black students. . . . [M]any whites felt they couldn't speak because the blacks would become so offended and angry. This class simply increased the racial tension between the students-imstead of educating the students to differing viewpoints.

A few people dominated the class and the teacher forced her opinion on the class....

Maybe she is too concerned about the individual feelings of the class. She really tries to avoid stepping on toes soinetimes to the detriment of the class and the inaterials.

Having talked to many students I can say that over $50 \%$ of the class suppressed their true feelings on one or inore subjects because of the intimidation felt in the classrooin.

On the whole, this was an interesting course and I think the professor has a true commitment to anti-discrimination. It must be risky to stand in front of a class and hear people's opinions that are racist and not respond, or even harder, to respond. Several tinies I found it almost impossible not to junp up and leave because cominents were inade that were blatantly racist and should have been nixed!

I feel certain of one thing in this complex situation: the teacher has a clear responsibility to try to understand how others in the class may feel when discussion centers on race. White students who have had little opportunity to think and talk about these issues may be experiencing high levels of anxiety and conflict. One of iny white students told me her perspective on this:

I have becoine more comfortable with the overall subject matter that is explored in this class. Getting off the slavery issue is in no sinall way responsible for this more coinfortable feeling. I didn't have to examine myself very deeply to understand why this is true. I didn't have to consider if I am a "closet racist."

I feel that the reason for this is that we are now getting into issues [of gender and employment law] about which I do not feel totally alienated. I have never been black, therefore, I couldn't possibly know the feelings of those who are and who feel that their color has played a major role in keeping them froin doing wliatever they cliose to do. I seemed to experience the most problems whien I did try to put myself in the slioes of 
others and sometimes felt that somewhere, somehow, I should have done something to try to make the situation better. Then the old guilt feelings took over and eventually I would become angry with myself and probably with the people for which I had been concerned, and I would think, I didn't do these things, then why should I feel like I owe anything to anybody. What emerged here was a vicious cycle of ill feelings, sometimes directed at others and sometimes directed at myself. I wanted to hiterally let out a giant WHEW when we moved on.

Similarly, members of racial minorities in a predominantly white group discussing matters of race often feel in a bind that few white people have imagined. One of my black students told me about his feelings:

In all candor I chose to take this course by default. ... I had hittle desire to take a class about discrimination offered by a school where my race (African-American) comprised a numerical minority.

It has been my experience that most white people are really not very interested in hearing abont the problems that Black people face in this country because of their blackness. The scenario is an all too familiar one. First, the subject is opened. Next comes a rush of well-travelled cliches in an attempt either to prove the absence of bigotry in the speaker, or to demonstrate a deep understanding of the problem. Fimally, conclnsory and transitional statements ease the conversation into another more worthy direction. Attempts to re-open discussion and show that bigotry wears many faces, sometimes imcluding the face that stares out of the mirror, are met with pained expressions and impatience. ... These interfaces, though typically low-key, mvariably result in ulcer-like abdominal pain for the African-American.

My experience has been that most white people aren't really very interested im hearing about the travails of the African in America. As an African-American, however, it's difficult for me not to speak about relevant facts in our history....

Most Black people know that most white people aren't particularly interested in hearing about their struggles. As a result, soon after they apprehend this, they simply don't initiate conversation on the subject. No one, Black or white, enjoys having something which they hold in great esteem minimized.

... And it seemed to me that if $I$ enrolled in Discrimination and the Law I would be faced with at least 40 days' worth of opportunities to feel that familiar stab of ulcer-like pain tearing through my viscera.

These cominents and others demonstrated that many students were using the reflection papers to creatively handle and process at least some of the powerful currents that were affecting the group and that the papers could prove to be an important way for me to gauge what was happening in the "underground" classrooin. Many students were raising issues, making arguinents, and expressing feelings that they did not want to raise publicly in class; they were telling stories that were too long or too 
personal for the larger group. ${ }^{135}$ Here are some of their reactions to the course format and materials:

I did not think of the effect that this class would have on me when I signed up for it. I expected a typical law school class format with civil rights cases substituted for tort or criminal cases or whatever curriculum a required law school course would have.... Now, I am very glad that this course is on my schedule, but $I$ am also somewhat afraid.

I am afraid first of all because I believe that I am going to learn some things about myself that I may not want to admit. I know that I am not a racist; of that I am not afraid. . . . But like everyone else, I do have prejudices, and I am going to have to admit them to myself. . . .

What I am more afraid of though, is that I am going to discover that our society is even more imperfect than I ever believed. . . .

Another recorded his reactions to the readings:

The more I read articles on discrimination, the more I look at blacks who do not know me and think, do they think I have racist feelings like the articles discuss? This makes me feel more on gnard and as a result, it adds distance. I am usually less aware of this and thus feel less like a racist. I feel I am being more racist when I am simultaneously concentrating on why I might be discriminating.

A black student also commented on some of the painful effects of increased awareness as he described his reaction to the documentary, Eyes on the Prize:

As I watched the documentary ... I could not help but reflect upon my "differentness." ... It was difficult to watch because it revealed the extent of the brutality of racism. ...

The documentary was also difficult to watch because I could not keep my eyes on the screen. I was quite mindful of the fact that I was surrounded by young white southerners. I kept watching thein and wondering if their thoughts of me were much different from those of their grandparents and parents. I kept wondering if $I$ could see it in their faces, hear it in their laughter, or their sighs.

A white female student wrote:

This [class] is painful. Reflection requires realizing that I have lived a sheltered existence in the center.

When I began the slavery material, I found that I did not want to know the details of specific slaves' lives. It is fairly easy to discuss slavery intellectually, generically, and in the past tense. It is far more difficult to realize that we come from a society that sold wives away from their husbands and sold mothers away from their children.

135. I should hasten to add that not all the students found them particularly helpful. Questions of style, taste, and methodology in the classroom can be as highly charged as matters of substance. One student opened his first effort with these observations: "This assignment is somewhat puzzling for me. If the purpose is to give my thoughts on the assigned readings, I'm afraid my comments will be very brief. While $I$ found the readings interesting, they provided me with no new information." 
A black woman observed:

I must admit that initially I was not very receptive to those persons with views different from my own.... I'm the type of person who is normally willing to reach a compromise, but because racial discrimination is such an important and unsettled issue, I found myself unable to digest much of the information.

To my surprise, the more I read and the more I histened to you discuss the issue in class, I began to realize that ignorance is truly not the answer. I needed to really begin to understand why people have views other than mine, to put myself in their position....

[B]ased on reading excerpts from the first set of [student reflection] papers, ... . awareness of the problems posed by race is lacking. This is a - major shock to me, but again I must try to put myself in the position of others. If nothing else is accomplished from this course, I hope we will be able to provoke an awareness ainongst members of the class in whom it is lacking and maybe they will carry it beyond the walls of the classrooin.

One student criticized our historical examination of slavery:

[I] would hike for this course to be a short history lesson and then get on to issues that are facing us today. I think that slavery was an atrocity that should not be repeated and I agree that we must know the past to understand the present and protect the future, however, I have had this history in high school classes, undergraduate history, Legal Process I, and I understand that it will be covered extensively in Constitutional Law, so I ain getting somewhat bored.

In the same round of papers another student observed:

As I histen to the lectures on slavery, I realize how little I know about the subject. My secondary education included some himited coverage of "Black History," but it never explored the intricacies of slavery. As I listen, I also wonder how many are in a similar (or worse) position .... I feel ignorant, deprived, and exploited. I feel miprisoned because I'm skeptical that I'll ever allow myself to becoine imformed about the subject of American slavery: I don't have time, I won't make time, others won't give me time. I feel that it matters to me, but does it really matter in America? Can a Black man (better-an African-American) "make it" in America if he places the knowledge of his physical and spiritual past among his priorities?

...

Racism hurts very much, and I've felt the pain. I want to listen, but it hurts, because I'm tired of the talk. TALK, TALK, TALK, TALK! It seeins for every step forward, we take another two steps backward .... Yet another student remarked:

The class inaterials concerning the emancipation of slaves and Reconstruction have been educating and frustrating. First, the materials have given me an opportunity to learn about my people-real and vivid 
accounts of my history. It's exciting to know that those testimonies are being formally shared in the educational system, especially in the legal system. Second, the inaterials have shown me that the law, in the hands of those who support or tolerate oppression, was and still can be devastating for those who are oppressed. That knowledge gives me the courage and determination necessary to complete my legal education and to take an active role in vindicating people's human rights.

Beyond discussing reactions to the readings and the class, student reflection papers also opened a series of individual windows onto the social experience of race im America, each with its own drama, each enriched and given context by the others around it. (They also served to remind me of the real diversity of behefs and experiences that exists even in a law school more homogeneous than inany.) Consider these comments froin a returning woman student with teenage children:

I had hints from Criminal Law I that there was an underlying motive and message to vagrancy laws. I was shocked to see how they arose in the Reconstruction South .... .

The attitudes of the white people in the Reconstruction era sounded very similar to the attitudes I heard routinely growing up in West Tennessee-talk of "uppity" blacks not knowing their place, how inherently inferior they were, basically lazy and "shiftless," untrustworthy and undependable. White girls like me should be especially fearful for what black men might do to us! Don't be too friendly; they would get the wrong idea. It wouldn't do any good to try to help thein; they just waste what you give them and aren't grateful anyway.

I grew up on a farm and worked in the fields with black people but between work times we spht up_to eat and rest. We drank from separate, large water containers! The black people did not like my father for very justifiable reasons. He inaintained a clear air of superiority and created an atmosphere of tension. The black field hands certainly showed deference to him but I knew there was a world of emotion behind their faces. To this day my father is a blatant racist, and $I$ have never coine to terms with it. When I go to visit him, the anticipation of his racist remarks fills me with dread.

Another younger student told his story:

The point I would like to discuss is one which I chose not to make in class because I was certain that I would be misunderstood . . . . The flip side of discrimination for reasons of greed and economic douninance is reverse discrimination. . . .

When I was in high school, I was told by iny basketball teammates (all black) to quit the team because they hated white people. I understand where blacks and other minorities may be bitter but discrimination will never end until both sides try. These remarks from iny teammates bothered ine because I liked these guys and gave them rides home after practice! Whites discriminated against them, they discriminated against me, and I was left to [feel] bitter towards blacks . . . . 
A man recently out of college offered these remarks:

I am from a southern family and grew up in a southern city .... Unfortunately, inost of my family is rather biased and racist towards blacks. . . . My aunt, a corporate executive in a Fortune 500 Company, works with inany blacks. But when at home, she refers to blacks as miggers. My uncle and cousin are even worse. Every single problem in our city is related to the blacks who make up a slight majority of the city. My cousin vows that blacks are not really humans but are descendants of monkeys. He claims that blacks will not and cannot be eqnal to white people.

I disagree with this view bnt I do not really express it to these members of my family. ... . If I do protest, I am attacking my own family and what they would call our heritage. These institutions (family [and] heritage) are so powerful [and] revered in the South. I have always been taught never to question the elders in the family. In addition, my family is so wonderful and supportive that it is difficult. Thus . . the dilemma: Am I perpetuating racism by not attacking it by attacking my family? ... I do not yet know how to resolve these conflicting but powerful feelings.

Another student observed:

I am persnaded that a key reason for discrimination lies not with anything we have discussed in class bnt with soinething much basermoney....

...

... I am as guilty as the next white person in terms of discriminating against the economieally disadvantaged. I grew up in Appalachia in a rather impoverished area. ... .

I don't choose to spend my time with people who are economically disadvantaged. I've been there. It's no fun. I think my attitude is typical of many whites who discriminate against Blacks. It is the economic position that many discriminate against, not the skin color. I would be happy for my children to attend school with Black children, however, I wouldn't want my children to attend school with children from poor [inner city neighborhoods] be they Black or White.

Another recalled:

For years, I thought the only blacks in our town were the gardener and the maid/babysitter that worked for my parents. It sounds silly to even admit now. I can still clearly recall the day I learned that Columbus (onr gardener/handyman) had kids. I remember asking "Why haven't I ever heard about this before? What are their names? How old are they? Why haven't I met them at school?"

It's not that my parents ever said anything about discrimination and race, it's the fact that they purposefully never spoke about the issues at all. I suppose their actions were based on the loose "Christian" principle of "if you can't say something mice, don't say anything at all." I think, also, they believed ... that if they ignored it, then it didn't exist as a problem for them. ... 
Even though I know that my parents had prejudice . . . against blacks, I also recall the compassion my parents showed to the few blacks that were in our lives. Like the time our black gardener walked MILES to our house after he had been accidentally burned on his face and hands. I remember him coming to the back door and asking for my Dad. When I started to open the door and invite him into the kitchen, he stopped me. I still remember his deep, kindly voice: 'I've been burned and I don't look so good now. I don't want you to get scared by looking at me. A hittle girl shouldn't have to see this." His face was burned, and yet he was concerned about how it would affect ine!

It was years later that I realized the white people Columbus had been working for when the accident happened wouldn't have helped him. He had walked all the way to our house because he knew that Dad would take him to the (white) hospital, pay, and see that he got medical care. ...

While he was recovering and couldn't work, we took Columbus food and money each week. This was the first tine in my life that I saw the "other side of town." I was amazed! A whole school full of black kids! Black churches, and lots and lots of houses, in a big part of town I didn't even know existed. I remeinber feeting totally amazed that there could be THAT MANY KIDS that I didn't even know (after all, I knew ALL the white kids in town.) I also remember asking, as we passed the black school, "Who teaches them?" It was the first time I reinember hearing the words "separate but equal."

A white female student told of vivid memories of violent protests over the singing of "Dixie" at her Tennessee high school and went on to describe an incident later in her hfe when a black wolnan who worked in the mailrooin of her building "grabbed me by the arm, pushed a steel letter opener to my throat, and let me know very clearly that she hated me and all white people." The student described her fear during and after the incident, the shame she felt for the fact that she had never taken any action against her attacker. She went on to observe:

I believe Eyes on the Prize is a true account of the black's struggle for equality at the hands of white people. I also believe that where this film stopped, a new attitude einerged, led by Stokely Carmichael and other militants, which was destructive and undermined much of the progress that had been made. In my house, you see, the riots and violence were "expected." It was just a matter of time.

Several white students had experienced brushes with racisin because friendships with blacks had exposed attitudes in others that would otherwise have remained invisible:

[As a staff worker in a recent presidential cainpaign], I went to Illinois to supervise the final week of petition gathering necessary to get us on the ballot in that state. I was staying in the home of some supporters in Champaign. A black friend of mine from Chicago agreed to come down and spend a couple of days helping me out. After my hosts met my 
friend . . . it was made clear to me that they would prefer we found somewhere else to stay. I was simply stunned that two educated people would be uncomfortable having a black man sleep in their home.

Similarly, another recalled:

Before coming to the University of Tennessee as a junior, I spent two years at, as Lewis Grizzard would say, "a large Southern Umiversity." The school is located in an agrarian setting right in the heart of the Deep South. There were almost no blacks enrolled at that school of eighteen thousand students, except of course for the athletes. I was living in some apartments that bordered campus. Some friends of mine came down from Nashville for Homeconing iny sophoinore year. One of those friends was a former high school football star who also happened to be black.

For reasons I can't recall, "Charles" decided not to go to the game on Saturday, choosing to stay in niy apartment and watch TV. Given the importance of football at this school, the apartment complex was virtually empty during the game. At some point during the game Charles stepped outside to look around a bit. As he was going back in the apartnient he was accosted by two local policenien. They came into the apartment, without a warrant, and proceeded to give my friend the third degree about who he was and what he was doing there. At first they did not seem to want to beheve that Charles was a friend of mine staying the weekend despite the fact that he had several pieces of identification as well as the key to iny apartment. If I recall correctly, they even went so far as to level threats against him. After putting him through this humiliation for a while the pohicc finally left.

... I will never forget how embarrassed and upset I was when I returned fron the game. For his part, I'in not sure that Charles left the apartnient the rest of the weekend. He just wanted to get out of there, and vowed to never return. As it turned out, I was not far behind him.

Another recalled an incident whose ambiguity has teased her, perhaps increasingly so as she learned more about the views and experiences of African-Americans:

My mother was a "working" nother. . . My brother, sister, and I had a series of babysitters/housekeepers. In keeping with the southern 1950's tradition, they were all black women.

On one particular hot, summer afternoon, my mother came hoine to discover her two daughters, five and six years old, blonde and red-haired, playing outside with the other white neighborhood children with their heads covered with multiple erect braids. . . . My mother was vastly amused though she did request that $m$ the future our hair remam loose or confined in a simple barrette. I have wondered on several occasions about the "feeling" which prompted this wontan to adorn us with what was so obviously a cultural coiffure.

Several years ago, after I recognized that iny father was a rather 
obvious racist, I contemplated the possibility of a more sinister reason. Could this woman, who had for most of her hife worked as a domestic for white families in the south, have intended to subtly insult my parents? Or engage in some spontaneous mischief not serious enough to result in her discharge but that could express her recognition of my parents' apparent sense of superiority? ... I am wholly unwilling to accept that she intended to subject my sister and me to the derision of our playmates. ...

The imterpretation with which I am most comfortable is that, from her perspective, it was an attractive and acceptable hair style . . . .

A woman who had been barely in her teens when chosen with one other black student to help desegregate a large local school in the upper South had this to say:

I was captivated by the film series Eyes on the Prize. [The film] catapulted me back imto time. I rehived sit-ins, the marches, and the school integration confrontations. I found myself remembering the frequent rides $\mathrm{m}$ the police paddy wagons and the over-crowded jails.

I found myself fightimg back tears and trying to control hostile feelings that had suddeuly engulfed me. I became frustrated and angry with myself to find even after all of these years I could be so deeply wounded over the past. I thought that I had overcome the world and its injustice with regard to race discrimination. I thought $I$ had truly developed the tolerance and love necessary to love those who []spitefully misused me. Eyes on the Prize exposed a part of me that revealed the cracks in my character that I thought were so minute and undetectable by the outside world. ...

... I saw my tormentors, and for the first time im my life, I wanted to make them feel my hurt, my despair, and my shame . . . .

A young white man observed:

Segregation still exists today. It exists by choice in both whites and blacks. . . . This "choice segregation" is very evident by driving down [the local college strip] on a Saturday might. Blacks hang out on the east end of the strip and whites hang out on the west side of the strip. The Knoxville Journal recently ran a story about "racial tensions" on the strip. That story was a total crock. I frequently visit the strip and I see how things work. Blacks don't stay away from the white side because whites don't want them, blacks stay on their own "end" because they prefer hanging out with blacks .... White people don't liang out on the "black end" because they choose to hang out with whites.

Fights do break out between blacks and whites. Fights break out also however, between whites and whites, blacks and blacks, old and young ....

$\ldots$

As far as racial tensions, more blacks start fights with whites, than whites start fights with blacks. (Largely due to the fact that blacks "liang 
out" in greater numbers.) Ten on four, eight on one. I've seen it and I'm not going to let the Knoxville Journal make these students in this school out to be a bunch of bigots.

Another related:

My county is divided into two regions, and [my half] has only one black resident ... A A KKK klavern assembles less than one mile from my hoine. When I was in high school we had a cross put im our yard with a message froin the Klan. It seems that they were upset because I played basketball with and against blacks. Even with all of this happening around me I never questioned its place im my life. I didn't think of blacks as inferior, inerely separate. It was not until I attended UT that I realized that separate is inferior.

I now try to reason out why [when I had a job where I was supposed to keep an eye on custoiners, I watched] blacks closer than whites, or why I notice when a black enters a room full of whites, or why there has never been a black man in either my hoine or my church.

Another recalled:

The county I am from is sinall. There are only about 18,000 people there. Less than $5 \%$ of the popnlation is black. There are no professional blacks in the work force. There are only two black teachers in the school systein. The blacks all he in two main neighborhoods in town and do not go to the restaurants or places where the whites go. They stay to themselves or in the margins. There is no real imtermixing of blacks and whites except within the athletic teams. I have never thought that the blacks in our town were staying in the margins, but in fact that is what they were doing.

After I sat for awhile and studied longer about the diagrain, I realized that $I$ ain one of the people on the inargin. Me, an upper middle class white person who has a college education and is studying to be an attorney, ain on the margin. I am a female trying to move into the predominantly inale oriented world of law. I realized these differences this summer when I worked at a large firm ... as a clerk. I was the only female out of seven clerks. I realized I was not treated as an equal when all the guys got to go play golf one day and no one even invited ine. . . .

All of the guys were very nice to me but they never really got to know nie. I heard all their stories all the time but they never really took the timie or seenied to really want to know about me. I was accepted if I stayed quiet and did not make any waves.

Another said:

I was raised in a fainily that was as void of racial prejudice as is possible. My fanily worked actively for civil rights and hived by their convictions. I have an adopted brother and sister that are Korean, and my fainily is very supportive of my present relationship with a black nran. And yet, as void of prejudice as I aln, and as happy as I ain with my companion, I still conteniplate whether I am doing the right thing, given the circumstances of iny relationship, by planning to marry and have children. I 
recognize that I would not lead a "normal life" and I worry about the burden we would put on our children. It is in this regard that I look to the strength, courage and foresight of the abolitionists.

Another student told of a recent incident that had stuck with her:

A week or so before school started, iny husband rented the inovie, "Betrayed." It was about an investigation by the CIA into . . . an atteinpt by "white supremacists" to annihilate the "undesirables" in America: Jews, homosexuals, and blacks. . . . [The movie ends with a young captured black man delivered in handcuffs by a county deputy and released like a game animal to be hunted and killed for sport.]

When I returned the movie to the rental store, a black couple was standing at the counter. The woman commented that she had seen it. I asked, "What year was this movie?" She said "1989." I thought she was saying when the inovie became available on video and clarified by asking, "No, what year was this story supposed to be?" She answered as if explanimg to a small child, "When the sun goes down."

After reading the papers I decided they were too interesting for me to hold a monopoly on them. I allowed students to designate their papers "not for publication," and a few students did so. All the others, however, I edited ${ }^{136}$ and anthologized without attribution and then xeroxed for distribution to the class. ${ }^{137}$

We repeated this process for a series of later rounds. ${ }^{138}$ Each stu-

136. Editing criteria gradually evolved to include the following: each person would have something included; repetitive or less interesting material was omitted; anything designated not for publication was, of course, culled out, along with any remarks that clearly identified the speaker or any other class meinber.

137. I learned that $I$ had to distribute these at the end of the hour or I would lose half the class members for as long as it took them to read through the handout.

138. The only change I made in the assignment was that for each group's second round of papers I instituted a system whereby students could turn in their papers anonymously. This was not for purposes of grading the papers because they were scored simply pass-fail and it would have taken drastic noncompliance with the assignment to fail. But I was aware (and specifically explained) that im an assignment of this kind im a course on this subject, some students might feel impelled to curry favor or avoid censure. One student observed in his first reflection paper:

The most memorable racial discrimination I witnessed was in a fraternity. People I knew

fairly well said a black could rush, but that a black was not going to get a bid. I remember

these people, who would be just as apt to take Discrimination and Law as anyone in this

class, and it makes me very skeptical of the lofty comments classmates make. I believe

some are being hypocritical and that secms like a bigger wall than the racism. ... I feel

they are not saying what they feel, but rather what sounds eloquent, idcal, compassionate, or what they think you want to hear.

I was not as pessimistic as this student in my reading of class discussions up to that early point but I certainly took his comments seriously. Although I could not follow up on student coinments, I believe the anonymity was a satisfactory addition and may have elicited a greater range of comments.

However, one important limitation must be noted. If African-American students wanted to include reflections on their racial identity or racial experiences, they lost a much greater degree of insulation from accurate gnesses about their identity than did white students because the ratio of black to white students was less than one to five. 
dent turned in two such papers by the end of the semester, each geared to a different set of readings and discussions. The edited and circulated versions then functioned as a kind of anonymous bulletin board or newsletter where class members could air opinions and reactions as we moved through the course.

For a large class handling a deeply divisive subject, I believe this inethod opened opportunities for protected expression and dialogue. In some ways tliese notes from the underground classroom will stay with me the longest and may in fact represent the heart of the experience. ${ }^{139}$ They also, I behieve, served as a further sigu that varying poimts of view, perspectives, and contributions were not only tolerated by the instructor but were an important part of the class.

I intended in Part II to show in concrete terms how one law teacher approached the teaching of race as a core feature of the American legal canon. I have paid attention both to the aboveground and underground aspects of the endeavor because I beheve both are important in the actual planning and teaching of courses. I also think that both aspects weigh heavily upon our imitial decision whether or not to proceed at all. ${ }^{140}$ In the next part of this Essay I want to revisit both Part I and Part II.

139. Cf. J.M. Balkin, The Footnote, 83 Nw. U.L. REv. 275 (1989) (playing delightfully with and beyond the idea that footnotes should not be "marginalized" (!) and that sometimes footnotes can be more important than the text).

140. In the course of a recent controversy at the University of Texas, for example, some faculty members planned a freshman writing course whose readings and written assignments would focus in large part on questions of race. A strong opponent of the plan observed: "If snch courses are to be taught responsibly, they must be taught by trained faculty members from disciplines like sociology, psychology, or cultural anthropology, not by English teachers. Being passionate about the issues doesn't confer the expertise to deal with them in the classroom." Maxine C. Hairston, Required Writing Courses Should Not Focus on Politically Charged Issues, Chron. Higher Educ., Jan. 23, 1991, at B1, col. 3.

As I suppose is already obvious, I fully acknowledge the explosive and otherwise difficult nature of race as a topic in the classroom. Nevertheless, I think that Hairston's position is seriously flawed. She presented race and racism as subjects that should be handled only by experts. If we give up on our own ability to deal with this subject directly despite its undeniable difficulties and the necessity for perspicacity and care, then it secms to me we truly have no hope of sigrificantly transcending our cnrrent predicament. See David Schoem, College Students Need Thoughtful, In-Depth Study of Race Relations, Chron. Higher Educ., Apr. 3, 1991, at A48, col. 1 (arguing that the academic setting is the most appropriate for studying race relations in-depth).

Further, I do believe there are concrete pedagogieal skills that teachers could learn that would help us navigate these waters. See, e.g., Katherine S. Mangan, Colleges Offer Cultural-Awareness Programs to Help Professors Undesstand Needs of Minority Students, Chron. Higher Educ., Mar. 6, 1991, at A11, col. 2. At my own institution two black women, with a grant from the Fund for the Improvement of Post Secondary Education, have developed a series of videotapes on race-charged student-teacher interactions and are using them to stimulate discussion and reflection among university teachers. Infonnation is available from Camille Hazeur and Dhyana Ziegler, University of Tennessee, Knoxville, TN 37996. 


\section{III \\ Race In The Law School Classroom and IN THE Legal Canon: The Thesis Revisited}

I began this Essay with a thesis about race and the canon in American legal education. First, I claimed that matters of race are centrally located in the core texts of American law and should be taught as central to our legal heritage. Second, I argued that legal educators should be able to reach common ground about that centrality and to do so with refreshing ease. Then, in Part II, I told some stories from my own teaching experiences in an effort to ground iny thesis in real texts and real students and to suggest ways that a law teacher inight begin to experiinent with the undertaking I urge.

Now in Part III I want to coinplicate the picture by revisiting both the theoretical canon debate and the concrete realities of practice in the classroom, this time focusing on solne of the thorniest questions. First, I will revisit Part II, taking up two teaching issues: (1) the presence and significance of values in the classrooin (the "indoctrination issue"); and (2) the difficulty of negotiating racial dynamics in the classrooin in a way that is both fair to and supportive of all students (doing "the right thing"). Next I will revisit Part I, probimg inore deeply into iny initial thesis that legal educators should be able to reach relatively easy consensus on the centrality of race to our tradition.

\section{A. The Classroom}

\section{On Indoctrination}

The debate about indoctrination in the classrooin is a strand of a larger debate about the ineanings and possibilities of objectivity. That larger debate has threaded its way through discussions of ethical standards for law teachers. ${ }^{141}$ It has fueled a inajor project of feminist juris-

141. In 1989, in a draft report, The Special Committee on the Ethical and Professional Responsibilities of Law Professors addressed the problem of objectivity and instructed professors to avoid using the classroom "to indoctrinate students concerning [their] political or social agenda." Association of American Law Schools, Draft Report of the Special Committee on the Ethical and Professional Responsibilities of Law Professors 5 (Jan. 1989) (section entitled "Responsibilities to Students") (emphasis added). However, the final draft recommended simply that "[t]eachers should nurture and protect intellectual freedom for their students and colleagues." Association of American Law Schools, Statement of Good Practices by Law Professors iu the Discharge of their Ethical and Professional Responsibilities 5 (Oct. 1989) (also known as the Byse Report).

Commenting on the initial draft report, Jeffrey Jackson coinpared "Professor-of-the-Year," a witty, well-prepared, dynamic teacher of the traditional case method, and "Professor-of-the-Left," a social critic who openly and eloquently expresses his political views and agenda in class:

Professor-of-the-Year seeins as much, if not more of an indoctrinator than Professorof-the-Left. Professor-of-the-Year's iudoctrination is more subtle and therefore probably harder for his students to identify and challenge. His concealment of his agenda, while not dishonest (indeed, he concealed his agenda because he honestly believed he should not force his views on his students), did not and will not lead to honest debate about that 
prudence, that of exposing the "inale norm" that is the unspoken and presumptively neutral starting point for so much legal analysis and social practice. ${ }^{142}$ It has also provoked a productive turn in feminist discourse under the leadership of feminist women of color. ${ }^{143}$

Issues of objectivity and indoctrimation also fuel the debate over the core curriculum with which this Essay began. Since the time I taught the discrimination class and wrote the first draft of this Essay, the canon debate has erupted into the nonacadermic press and has risen im both volume and pitch. The question of indoctrination looms large in this latest turu in the conversation. ${ }^{144}$

agenda. On the other hand, Professor-of-the-Left takes his responsibility to act on his deeply held moral convictions seriously and therefore he spreads his good news for the benefit of his students. He too is an indoctrinator-but he is more candid about his agenda. ...

$\ldots$.

Indoctrination should not be condemned. Instead it should be acknowledged.

Jeffrey Jackson, Commentary on the Byse Report 5-7 (Aug. 10-12, 1989) (paper delivered to AALS Southeastern Regional Meeting) (on file with author).

142. See, e.g., Lucinda M. Finley, Transcending Equality Theory: A Way Out of the Maternity and the Workplace Debate, 86 Colum. L. REv. 1118, 1120 (1986) ("Our legal system . . . [1]eaves unquestioned the notion that life patterns and values that are stereotypically male are the norm.").

A story that I believe began as fact but has now passed into legal feminist folklore is the story of the woman judge who was sitting in a sex discrimination case. Counsel for the defense inoved that she excuse herself because she could not help but be biased since she was a woman! The assumption by this fabled counsel that a unale judge would be neutral appears to be as unconscious as it is incongruous. Professor Jerome Culp addressed an analogous, although more complex, example of this same phenomenon in the context of a black judge who was ordered to excnse himself from a school desegregation ease because of his past involvement as a desegregation advocate. See Culp, supra note 14 , at $58-62$.

143. See, e.g., B. Hooks, supra note 42 (feminist theory itself has often fallen prey to a presumptive white iniddle-class norm, thus failing to appreciate or address the experiences and needs of most black women); Bell HoOKS, AIN'T I A WOMAN: BLACK WOMEN AND FEMINISM (1981) (inpact of sexism on black women throughout history); GLORIA I. JOSEPH \& JILL LEWIS, COMMON Differences: Conflicts in BLACK aNd White Feminist Perspectives (1981) (racial and sexual factors have both contributed to the oppression of women and are often assessed differently by black and white women); Elizabeth V. SPElman, The INESSENTIal Woman: Problems of EXCLUSION IN FEMINIST THOUGHT (1988) (notion of "woman" in femimist theory often serves to mask the heterogeneity of women); THIS BRIDGE CALLED MY BACK: WRITING BY RADICAL WOMEN of Color (Cherrie Moraga \& Gloria Anzaldúa eds. 1989) (different kinds of women should listen to each other and learn each other's ways of seeing and being); Harris, supra note 14, at 581 (experience of black women is often ignored in both feminist and legal theory); Elizabeth Higginbotham, Feminism and the Academy, 2 NAT'L WOMEN's STUD. A.J. 105 (1990) (diversity of women's experiences needs to be better reflected in feminist scholarship); Marlee Kline, Race, Racism, and Feminist Legal Theory, 12 HARV. WOMEN's L.J. 115 (1989) (diversity of women's experience of oppression based on gender and race is often obscured in writings of white feminist legal scholars). Other sources on the same subject include a number of publieations available from the Center for Research on Women at Memphis State Uiniversity: Patricia H. Collims, Toward a New Vision: Race, Class and Gender as Categories of Analysis \& Connection (May 24, 1989) (keynote address delivered at a workshop on Integrating Race and Gender imto the College Curriculum); Higginbotham, supra note 5; Lynn W. Cannon, Elizabeth Higginbotham \& Marianne L. A. Leung, Race and Class Bias in Research on Women: A Methodological Note (Res. Paper No. 5, 1987).

144. William J. Bennett, for example, now a semior fellow in cultural-policy studies at the Heritage Foundation, said " there are those on campus doing exactly what the American people 


\section{A series of well-placed articles recently has described a "crisis" in higher education. ${ }^{145}$ The articles synthesized previously disparate}

have feared and have now discovered-ideological brainwashing.' " Stephen Burd, Bennett: 'I Mean, It's a Disaster', Chron. Higher Educ., Oct. 23, 1991, at A5, col. 5.

145. See, e.g., ArLynn L. Presser, The Politically Correct Law School: Where It's Right to be Left, A.B.A. J., Sept. 1991, at 52 (reporting that law schools too are involved in this controversy); Dinesh D'Souza, In the Name of Academic Freedom, Colleges Should Back Professors Against Students' Demands for 'Correct' Views, Chron. Higher Educ., Apr. 24, 1991, at B1, col. 2 (voicing concerns about what author sees as routine intimidation of "politically incorrect" professors); The Wrong Way to Reduce Campus Tensions: A Statement by the National Association of Scholars, Chron. Higher Educ., Apr. 24, 1991, at A15 (advertiseinent stating that recent university policies and practices, including the preferential treatment of ethnic minorities, undermine tolerance and fairness); William A. Henry III, Upside Down in the Groves of Academe, TimE, Apr. 1, 1991, at 66 (reporting that "a new intolerance is on the rise," and sharing "[b]ulletins from the P.C. [f]ront"); Dinesh D'Souza, Illiberal Education, ATlANTIC MoNTHLY, Mar. 1991, at 51 [hereinafter D'Souza, Illiberal Education] (containing a lengthy preview of Dinesh D'Souza's book of the saine name which has since been released and becoine a best seller); NEw REPUBLIC, Feb. 19, 1991 (devoted alınost entirely to the subject of race on campus, reporting what it sces as a pathological racial unease fueled by multiculturalisin gone awry); Taylor, supra note 130 (exainining the tensions that the so-called politically correct inovement has caused); NewSwEEK, Dec. 24, 1990 (criticizing the "New McCarthyism" of pohitical correctness).

Responses, both positive and negative, to these and similar articles, and now to D'Souza's book, have not been long in coming. See, e.g., Daphne Patai, Minority Status and the Stigma of 'Surplus Visibility', Chron. Higher Educ., Oct. 30, 1991, at A52, col. 1 (arguing that inuch of the heat in the antimulticulturalist campaign can be attributed to the fact that "[f]or those who long have been in positions of dominance, any space that minorities occupy appears excessive and the voiees they raise sound loud and offensive"); Patricia J. Williams, Blockbusting the Canon, Ms., Sept./Oct. 1991, at 59 (criticizing and describing the soinetimes chilhing effects of attacks on inulticulturalism); Maurice Isserman, Travels with Dinesh (Book Review), TikKun, Sept./Oct. 1991, at 81 (reviewing D'Souza's Illiberal Education and criticizing his methodology and conclusions); Catharine R. Stimpson, Big Man on Campus, Nation, Sept. 30, 1991, at 378 (critieizing D'Souza's book for inaccuracies and self-serving omissions); Wiener, supra note 130 (criticizing as grossly inaccurate the treatment of an incident at Harvard by both D'Souza and Taylor); G. Calvin Maekenzie, Fallacies of PC, Chron. Higher Educ., Sept. 4, 1991, at B1, col. 2 (argning that the campaign against political correctness is inappropriately alarmist); C. Vann Woodward, Freedom \& the Universities, N.Y. Review of Books, Jul. 18, 1991, at 32 (sympathetically reviewing Illiberal Education); Peter Erickson, Rather Than Reject a Common Culture, Multiculturalism Advocates a More Complicated Route by Which to Achieve It, Chron. Higher Educ., June 26, 1991, at B1, col. 2 (calling upon multieulturalists to respond to recent attacks by explaining that a common culture must be continually "created anew by engaging the cultural differences that are part of American life," id. at B2, col. 4); Bob Beyers, Machiavelli Loses Ground at Stanford; Bible Holds Its Own, Chron. Higher Educ., June 19, 1991, at B2, col. 1 (critically responding to D'Souza); Michael Berube, Public Image Limited: Political Correctness and the Media's Big Lie, Village Voice, June 18, 1991, at 31, col. 1 (critically reviewing books by Alan Blooin and Roger Kimball, Taylor's New York article, and the Atlantic's preview of D'Souza's Illiberal Education); Richard Goldstein, The Politics of Political Correctness, Village Voice, June 18, 1991, at 39, col. 1 (criticizing the campaign against "P.C." as giving people an excuse to avoid difficult questions about race and gender); Stephen Greenblatt, The Best Way to Kill Our Literary Inheritance Is to Turn It into a Decorous Celebration of the New World Order, Chron. Higher Educ., June 12, 1991, at B1, col. 2 (responding to article by George Will that criticized professors of literature who examine racial, gender, and social issues in literature); Katharine $T$. Bartlett, Some Factual Correctness About Political Correctness, Wall St. J., June 6, 1991, at A17, col. 3 (law professor at Duke University criticizing campaign against "P.C." for miscliaracterizing the movement and failing to address the important substantive issues underlying controversy); Catharine R. Stimpson, New 'Politically Correct' Metaphors Insult Hislory and Our Campuses, Chron. Higher Educ., May 29, 1991, at A40, col. 1 (describing history of antinulticulturalism 
themes, weaving them together into an exposé and warning. ${ }^{146}$ The authors portrayed the integrity of the American university as threatened by a tangle of destructive attitudes and practices, one of which is an oppressive new orthodoxy of multiculturahism. This spate of articles demonstrates a new turn in the canon debate, not ouly in the success of its attempt to project the debate beyond academia, ${ }^{147}$ and not ouly in the troublingly nasty tone of soine of the recent pronouncements, ${ }^{148}$ but also in the characterization of "the problem" in broader terms. Now the dan-

campaign and accusing it of "sloppiness about the facts," "selective use of evidence," and "manipulation of fear"); Eugene Genovese, Heresy, Yes-Sensitivity, No: An Argument for Counterterrorism in the Academy, NEw Republic, Apr. 15, 1991, at 30 (seconding D'Souza's views on the corrosive effects of multiculturalism); Paula Rothenberg, Critics of Attempts to Democratize the Curriculum Are Waging a Campaign to Misrepresent the Work of Responsible Professors, Chron. Higher Educ., Apr. 10, 1991, at B1, col. 2 (responding to Newsweek and other articles that had reported disapprovingly on her 1988 book Racism and Sexism: An Integrated Study).

146. The original spate of "anti-P.C." articles described what the authors saw as multiculturalist excess and deplored the proliferation of "politically correct" students, professors, and administrators whom they portrayed as a dominant force on most campuses. ("Politically correct" is a phrase originally coined by the left, usually levelled as a mocking criticism of fellow critics who had become too narrowly and rigidly bound to some position or principle whose significance they overrated. Appropriated by the right, it has now permeated all parts of the spectrum as a solemn buzzword in the controversy.) See, e.g., NEw REPUBL1c, Feb. 18, 1991. Most sensationalist, perhaps, was an article that opened with a full-page collage of Chinese Red Guards punishing dissenters and gloating Nazis burning books during the $1930 \mathrm{~s}$. See Taylor, supra note 130 , at 33. One of the most troubling features of these reports is their frequent imphication that those questioning the traditional canon, pushing for diversity, or advocating multicultural experiences in the classrooin take a kind of diabolical pleasure in attacking all that others hold dear. For some sense of how painful the act of criticism can be, even for the critic herself, see ADRIENNE RICH, Twenty-One Love Poems, in THE DREAM of A COMMON LANGUAGE: PoEMS 1974-1977, at 27 (1978) ("[o]nce open the books, you have to face the underside of everything you've loved").

147. Dinesh D'Souza, for example, spoke of wanting to "mend" the "troubling ignorance" of the American public regarding the "revolution" that allegedly had taken place in our universities. See D'Souza, Illiberal Education, supra note 145. And in fact the controversy has to an amazing degree become a matter of popular polemics, with contributions from conservative columnists (for example, James Kilpatrick, Intellectual Virus: Newly Fashionable Multiculturalism Threatens Fundamental Western Values, Knoxville News-Sentinel, Feb. 11, 1991, at A6, col. 1; George Will, Political Indoctrination Supplants Education, Knoxville J., Sept. 27, 1990, at 16A, col. 3); and even the President (for example, Christopher Myers, Many Praise Bush for Lashing Out at 'Political Correctness' Concept, but Others See Misrepresentation, Chron. Higher Educ., May 15, 1991, at A23, col. 1; John E. Yang, President Assails Silencing of Unpopular Viewpoints: Speech Denounces 'Politics of Division', Wash. Post, May 5, 1991, at A8, col. 5).

148. Boston University President John Silber, attending a conference sponsored by the Madison Center, reportedly "called upon speakers to discredit scholars whose work they considered politicized or shoddy. 'Why be so civil? Why be so cordial?' he said, adding that such scholars could be discredited 'if they were subjected to the ridicule they so richly deserve." " Carolyn J. Mooney, Scholars Decry Campus Hostility to Western Culture at a Time When More Nations Embrace Its Values, Chron. Higher Educ., Jan, 30, 1991, at A16, col. 1.

The tone of these complaints startles me. The people I know who are the most interested in multiculturalism are (a) not totalitarian zcalots and (b) seldom in positions of significant power. Frankly, it is difficult for a person in nyy position (new, female, untenured, coinmitted to race as a central issue for the law and for legal education) not to feel alarmed at this rhetoric. The approach to legal education I have described and advocated in this Essay would surely subject me to accusations of indoctrination from these canon defenders. 
ger is cast not simply as one of canon erosion but rather as the infiltration into the university of a whole web of destructive behiefs and practices that are ostensibly involved in inulticulturalism. ${ }^{149}$ One of the practices of which multiculturalists are accused is the use of the classroom as a site for indoctrination.

From my vantage point, it is not the conservative critics but scholars and teachers calling for a newly inclusive academy who have the most reasonable grounds for fear. ${ }^{150}$ When I look around at the institutions of

149. One of the distinctive features of this new turn is its "multi-issue" theme. Some of the strands knitted together in the campaign against the "politically correct" are: (1) defense of a traditional western (although now somewhat modulated) canon; (2) the celebration of meritocracy (undergirded by a strong faith that we once enjoyed such a systein and could define it again by a set of relatively unproblematic neutral standards); (3) the denunciation of affirmative action in hiring and admissions as both unfair and meffective; (4) the embrace of scholarly objectivity and rejection of relativisin; and (5) the charge that advocates of an expanded canon and a more inclusive university have iromically created an atınosphere where freedom of speech and thought are stifled rather than nourished. See sources cited supra note 145 . This is a broad agenda indeed-and an important one.

Exemplifying this inultifaceted vision, one commentator has stated: "[T] .... The real issues-the ones underlying a wide range of campus debates-inelude the assumption by many that Western values are inherently oppressive, that the chief purpose of education is political transformation, and that all standards are arbitrary." D'Souza, Illiberal Education, supra note 145, at 51 (editor's imtroduction) (emphasis in original).

I do not beheve that either the tone or the individual components of this synthesis will prove persuasive to many in academia. As to affirmative action, though for healthy functioning it needs inore close attention and concrete care in administration than it sometimes receives, too many of us know too well the reasons why it has developed and the debilitating costs that would follow its abandonment. As to multiculturalist expansion of texts and subjects studied, too inany of us are too excited at what newcomer texts and newcomer voices are bringing to university offices and classrooms and are also too aware of continumg racial disparities and divisions and of demographic trends to feel that we can or should put the challenges of multiculturalism aside. As to the ideal of neutrality, too inany of us are too much children of the twentieth century to rally to purist calls for a return to unproblematic "objectivity."

There will, of course, be many spirited disagreements about what kinds of affirmative action we should implement on whose behalf, about what kinds of canon expansion we should undertake, and about what kinds of strategies and principles we can einploy to challenge and evaluate our own and others' claims in a world where we can no longer assert the objectivity of values. But this is precisely the stuff of an exciting intellectual and institutional life.

150. One source of this fcar has to do with the difficulty of dialogue in the atmosphere created by the "anti-P.C." campaign. The way canon defenders have strnctured their critique (branding multiculturalists as people bent upon bringing their own zealous agendas into academic discourse and pushing their own values down the throats of powerless and disoriented students) has a peculiarly potent ability to stop or to poison further conversation. Those who attack inulticulturalisin have called foul about what they sce as the conversation-stopping quality of some multiculturalist discourse. This is a complaint $I$ believe must be taken seriously. If the canon defenders wish to be even minimally consistent or fair, however, they should examine their own moves.

A second source of this fear has to do with the tone of some of the attacks already mentioned above. Likely neither side has a monopoly on name-calling or on truth. But when I see that a conference keynoted by the chair of the National Endowment for the Humanities also featured speakers who decried "radical anti-Americanism" and "agreed it was important to 'name names" (Mooney, supra note 148), or when I hear one critic of inulticulturalism opining that "[w]e are again witnessing the growth of conspiratorial forms of campus radicalism" (Fred Siegel, The Cult of 
which I am a part, it appears to me that traditional patterns of race and gender distribution remain largely imtact. Changes have occurred but the progress is uneven, uncertain, and slow. And at least in my environment, the notion that multiculturalism has grown sick on its own power sounds bizarre. ${ }^{151}$

Of course my interpretation is contestable. It is a strange feature of these debates that people on both sides speak as though they feel vulnerable and powerless. Dinesh D'Souza said, "Most university presidents and deans cooperate with the project to transform liberal education in the name of minority victims" and described advocates for inclusiveness as " $m$ many places dominant."152 A professor speaking at the Umiversity

Multiculturalism, NEW REPUBLIC, Feb. 18, 1991, at 34, 35), then I shiver. When I pick up my local campus newspaper and see the following description of the threat posed to the university by people like me, I believe that its author has misperceived the threat:

PC refers to a revolutionary movement within American universities all across the country. PC is a way of thiuking, and this way of thinking leads to authoritarian conclusions about what the goals and methods of universities ought to be. It is a serious threat to American universities and the students who will be studying there....

... Many of [the PC] conclude that Western culture is inherently inferior ....

$\ldots$

They also formulate the content of the courses and present their course material in a way to further their political agenda. Books are chosen on the basis only of the race or gender of the author and the anti-Western message they promote. ...

The PC also take a hostile stance toward individual freedom. ...

$\ldots$

... My department, political science, has been convicted of racism without a trial because it lacks a black faculty inember. The mere assertion is conviction, no argument or proof required. This absurd method represents the McCarthyistic tactics of the PC-yes, they're even here at U.T.

Stephen Clark, New McCarthyism Threatens Campus, Daily Beacon, Mar. 7, 1991, at 4, col. 1.

151. Although this is hard to docunient, a few scattered facts may provide sone flavor if not concrete support. Fewer than $10 \%$ of our students are nonwhite. There is not a single gay or lesbian law student on our campus who has yet made his or her sexual orientation known to the law school comnumity at large. Until last fall, there was no course that dealt in any significant way with femmist legal theory. We have no courses on comparative law.

I do not recite these facts in order to assign blame. Multiple factors contribute to the atmosphere here, which is not unlike that at many other fine law schools. Remembering the specifics of a rcal institution can, however, cast a somewhat different light on the crisis of "Multiculturalism Triumphant" as it is depicted in some recent articles.

The substantive charges of atteinpted thought-control and coerced conformity that the same articles level against those who are pressing for the greater inclusion of "outsider" texts and people in the academy are a similar distortion. I urge both my colleagues and my students to measure the charges carefully against their own experience and against the facts because I believe if they do so, they must fairly conclude that the attack is profoundly off the mark.

152. D'Souza, Illiberal Education, supra note 145, at 55, 57. In my own view the generous resources that have been visited upon Mr. D'Souza himself are worth noting in this regard. Of course, it is quite proper for people and corporations and foundations of all stripes to fund and groom thinkers and activists of whon they approve. Likewise, however, it is helpful for all concerned to be aware of the players who have involved theniselves in particular controversies. During his Ivy League undergraduate days, Mr. D'Souza was editor-in-chief of the Dartmouth Review, one of a network of conservative newspapers that began to emerge on college campuses early in the 1980s, supported by conservative funders like the Oliu Foundation. He went on to edit a Heritage Foundation quarterly, to serve as a domestic policy analyst in the Reagan White House, 
of Pennsylvania apparently felt so embattled that he called upon his traditionalist colleagues to help create "the monasteries of a new dark ages, preserving what is worth preserving amid the barbaric ravages in the countrysides and towns of academe."153 On the other hand, a young faculty member from another umiversity observed that " '[j] ust as these voices are being heard, they're being bashed as robotic arbiters of political correctness. It's an effective tool, the powerful presentimg themselves as powerless." "154

At any rate, the controversy now raging about the canon, diversity, and the mission of the umversity creates a highly charged environment in which to be struggling with the indoctrination issue. My own sense is that for a good teacher there would be some degree of irreducible dilemma even if the "P.C. Wars" had not begun. I will address that dilemma in the remarks that follow.

First, I find it relatively easy (perhaps because it seems to me so inescapably necessary) to reject aspirations to pure objectivity or neutrality. None of us is capable of having a God's-eye view of the world or its people, and the result of aspiring to achieve such a fiction is an unacknowledged poimt of view, surely more pernicious and misleadimg than a committed but acknowledged one. ${ }^{155}$ As one participant in the curriculum debate observed:

and to join the American Enterprise Institute. See Denise K. Magner, Piercing the Posturing and Taboo' of Debate on Campus Reforms, Chron. Higher Educ., Apr. 10, 1991, at A3, col. 2.

153. Debra E. Blum, Scholars Who See Colleges in the Thrall of Politics Meet to Plan a Counterattack, Chron. Higher Educ., June 20, 1990, at A16, col. 5. The professor spoke at a meeting of the National Association of Scholars that was called to address what its inembers claimed was an increasingly hostile environnent for scholars who hold traditional views on academic matters. Id. at A15, col. 3. The Association held its third annual neeting in fall 1991. Denise K. Magner, Gathering to Assess Battle Against 'Political Correctness,' Scholars Look for New Ways to Resist 'Illiberal Radicals'; Chron. Higher Educ., Oct. 30, 1991, at A17, col. 2. The National Association of Scholars is only one of the organizations now focusing its energies on this controversy. See Mooney, supra note 148, at A16, col. 3 (reporting that former secretary of education William J. Bennett and Professor Allan Bloom of the University of Chicago are involved with an organization that has held two widely pnblicized conferences, plans an "acadenic guide to colleges," and runs a "network for student newspapers founded to provide an alternative-more conservative-voice to mainstream student publications"); see also Carolyn J. Mooney, Academic Group Fighting the 'Politically Correct Left' Gains Momentum, Chron. Higher Educ., Dec. 12, 1990, at A1, col. 2; Scott Heller, Collegcs Becoming Havens of 'Political Correctness,'Some Scholars Say, Chron. Higher Educ., Nov. 21, 1990, at A14, col. 2. The New York Tinies recently reported that canon expanders are also organizing and have formed a new group called Teachers for a Democratic Culture. Anthony DePalma, In Battle on Political Correctness, Scholars Begin a Counteroffensive, N.Y. Times, Sept. 25, 1991, at A1, col. 1 .

154. Heller, supra, note 153, at A14, col. 1 (quoting Associate Professor of English at the University of California at Berkeley, Susan Schweiber).

155. See generally Minow, supra note 41 ("[W] may appear partial from another point of view. . . . Regardless of which perspective ultimately seenus persuasive, the possibility of multiple viewpoints challenges the assuniption of objectivity and shows how claims to knowledge bear the imprint of those naking the clainis." Id. at 14); see also Jackson, supra note 141, at 7 (arguing that indoctrination should be acknowledged rather than condemned). 
[Those arguing for inclusion of African-American literature in a core curriculum] face the outraged reactions of those custodians of Western culture who protest that the canon, that transparent decanter of Western values, may become-breathe the word-politicized. That people can maintain a straight face while they protest the irruption of politics into something that has always been pohtical-well, it says something about how remarkably successful official literary histories have been in presenting themselves as natural objects, untainted by worldly interests. ${ }^{156}$

I view as naive the notion that a law school course like mine is biased if it tries to be antiracist or makes persistent efforts to entertain the perspective of people "on the margin." On the contrary, conscious inclusion of multiple perspectives is called for on objectivist terms in the sense that such inclusion and awareness should help students come closer to perceiving a "relatively truer truth" than one wedded to an unacknowledged viewpoint. ${ }^{157}$

In the service of this "truer truth" students need to encounter forcefully stated arguinents froin a range of viewpoints on the issues they study. They need to learn to recognize different approaches to legal probleins, especially approaches that are rooted in our national narratives and dilemmas. In furtherance of this goal they need to be exposed to strong writers who differ markedly with each other. So a syllabus should include representatives of varying positions, and class discussions should give serious attention to these differences.

All these lofty descriptions fit nicely with the notion that a teacher should not be an indoctrinator but should respect the autonomy and integrity of her students. They support my hope that in the classes I lead, all of us will be deeply challenged and forced into unanticipated self-examinations and will be enabled to see our own previous knowledge and convictions from new and unsettling angles. I believe that I should take as many risks as I ask my students to take and I should be ready and

156. Henry Louis Gates, Jr., Whose Canon Is It Anyway? (Book Review), N.Y. Times, Feb. 26, 1989 , § 7, at 45 , col. 1 .

157. Objectivity is no simple term, and the most astute scholars refuse to accept a clear dichotomy between objectivity and relativism. Historian Limda Gordon, for example, observed at a recent meetimg of the American Historical Association that "[a]ttention to the craft of historical scholarship shows that few historians claim to be either purely objective or relativist." Karen J. Winkler, Challenging Traditional Views, Some Historians Say Their Scholarship May Not Be Truly Objective, Chron. Higher Educ., Jan. 16, 1991, at A5, col. 1. She said that conservative academics who oppose affirmative action and oppose expansion of the canon "claim to be objectivists defending the academy against relativists. In fact, the other side do not consider themselves to be relativists at all .... They are advocating their own, more complex form of an objectivist position.'" Id. at A6, col. 1; cf. Mooney, supra note 148, at A16, col. 1 (quoting Boston University President John Silber saying that higher education is suffering from "profound relativism"); D'Souza, Illiberal Education, supra note 145 , at 76 (" $[t]$ he new critics go beyond the assertion of contingent knowledge to suggest that the very idcal of objectivity is a mirage"). 
willing to have my own ideas publicly subjected to searching criticism. Teachers should empower students to pursue their own future learning, not teach them to sit quietly im order to be filled with present information. If we cannot be neutral, we can try to foster classrooms that are challengingly and liberatimgly plural.

There is, lowever, another problem, which is why there is a dilemma. It is relatively easy to conclude that a teacher should offer students a variety of perspectives, but less so to define what role the teacher's own values should play in the classrooin. My aim is not to convert students to my own personal positions on various issues. But I must confess to feeling certain that my own positions on some issues are right, ${ }^{158}$ and in soine cases I do want to change my students. I am sure, for exainple, that more people in the United States need to learn the history of racism in America and the profound way it has shaped our legal institutions, our culture, and our daily lives.

Further, if I encounter in a student, male or femnale, black or white, what I consider to be racist or sexist assumptions, I would hope that experiences in a class I lead might help the student to question or unseat sucli assumptions. And if a student decides as a result of a class I lead that lie or slie would like to do soniething to fight the effects of racisin in society, or to work at dividing the chores ni his or her household or law firm niore equitably, or to search for a more congenial career path, that would make me very happy. Moreover, I find profoundly disturbing any philosopliy of education that would say my orientation should be otherwise on this score. ${ }^{159}$ These views of mine by necessity place me in a

158. In the current climate I find myself fearful that if I attempt to expose students to various views but also make it clear where my own values lie, I will appear to be proving the traditionalists' charge that all us multicultural zealots are bent on indoctrination. The very act of initiating dialogues with my students on matters $I$ take to be of human and social importance, especially if $I$ am asking them to question previously unexamined assumptions, I now fear may be interpreted by some of those students or some of my colleagues as an autlioritarian imposition of my own point of view. Patricia Williams puts it this way in the context of deciding how to respond to certain cliallenges:

The dilemma $I$ face at this moment in the academic world is: if $I$ respond to or open discussion about offensive remarks from students in my classes, I am called "PC" and aceused of forcing my opimions down the throats of my students-and of not teaching them the real subject matter. If I respond with no matter what degree of clear, dignified control, I become a militant black female who terrifies "moderate" students. If I follow the prevalent advice of "just ignoring it," then I am perceived as weak, liumiliated, ineffectual, a doormat.

Williams, supro note 145 , at 63 .

159. Thinking about how mescapably nornative these matters are, I am reminded of a memorable outburst of Arthur Leff's. In a commentary on law and economics Leff observed the paradoxical unavoidability of normative judgments in a world where "the knowledge of good and evil as an intellectual subject [has been] systematieally and effectively destroyed . . . a fact of modern intellectual life so well and painfully known as to be one of the few which is simultaneously lorrifying and banal." Arthur A. Leff, Commentary: Economic Analysis of Law: Some Realism about Nominalism, 60 VA. L. REV. $451,454-55$ (1974). He finally concludes: 
certain relationship to the subject matter of a course on race, for example, and in soine tension with the "indoctrination critique."160

Further, even if one could resolve this dilemma on the level of highminded abstractions, the life of the classroom is fraught with the concrete frailties of real people in real settings. In my own case, fear of conflict and self-absorbed enthusiasm for my own views are both ever-present enemies. I too easily find myself suppressing useful outcroppings of confiict in the classroom. ${ }^{161}$ I too seldom pose arguments I despise in their

I don't know how one talks about it, but napalming babies is bad, and so is letting thein or even their culpable parents starve, freeze, or inerely suffer plain miserable discomfort while other people, inore "valuable" than they are or not, freely choose snowmobiles and whipped cream. ... And "the law" has always known it; that is the source of its tension and complexity.

Id. at 481 (emphasis in original). I am not at all certain that most of my students would recognize Leff's first observation as well known or banal, but the force of his exclanation is not thereby diminished.

160. To illustrate, I recently read a news report about different colleges and universities that were beginning to include courses on race and/or ethnicity as part of their general education requirements. Two philosophy professors at one such institution were disturbed at the new requirement and had circulated a statement in protest. They observed: "As we all know, the course in question was introduced with the intention of changing students' attitudes about race relations ... . [I]ndoctrination [is] starkly inappropriate.'" Denise K. Magner, Difficult Questions Face Colleges That Require Students to Take Courses That Explore Issues Relating to Race, Chron. Higher Educ., Mar. 28, 1990, at A20, col. 1 (emphasis added). This conflation of the "intention of changing student attitudes" with "starkly inappropriate indoctrination" is almost unintelligible to me. It simply nakes no sense to argne that it is indoctrination to try to change students' racist, sexist, or ehtist attitudes but not indoctrination to encourage students to see the value in respeeting the rights of the accused, to train them to think "like lawyers," to cousel female students against emotionalism in class discussious of rape, or to urge studeut reconciliation and adjustment to a tort system that imposes no duty to rescue on a stranger. All these endeavors in fact go on in law schools all the time. The value and nieaning of each such endeavor, both in theory and as practiced, is debatable on its inerits. Each is also deeply value-laden and political.

161. One student offered a criticisin: "I think that it would be beneficial if you or another student agreed to play 'devil's advocate' for controversial issues in class. I think that class would be nuch nore productive if it didn't just assume one point of view without full debate." The notion that these class sessions represented only one point of view is very far from niy own perception. I believe soine students see sameness where professors see difference because of the difficulty they (and all of us) have in distinguishing between two things that are unfauniliar. See generally Jared Diamond, The Ethnobiologist's Dilemma, NAT. HIST., June 1989, at 26 (how different cultures perceive and organize information); Jared Diamond, This-Fellow Frog, Name Belong-Him Dakwo, NAT. Hist., Apr. 1989, at 16 (different cultures vary in the factors they use to identify things). But receiving an observation and suggestion of this kind nuakes me reexamine iny classroon practices.

There were times in the Discrimination class when I think I smoothed over conflicts or blunted interactions that would liave been more fruitful if allowed to proceed. Usually the snoothing and blunting activity was fairly subtle, and usually it was well under way before I eveu recognized what I was up to. Further, it was reasonable for ine to be concerned about individuals getting lurt: the subjects uuder discussion were often difficult. But I believe I need to increase my own conflict threshold and to have inore faitl that student thresholds will be ligh enough to tolerate creative discord as well.

Since tcaching the course I have read thoughtful explorations of the almost involuntary ways teachers can stifle the very kinds of interactions they inost desire. See Howard Lesnick, Reassessing Law Schooling: The Sterling Forest Group, 53 N.Y.U. L. REV. 561, 565 (1978) (insider analysis of reactions that discouraged rather than encouraged class participation); see also Toni Pickard, 
best and toughest form. One way to avoid having one's own view predominate is to structure classes or topics as debates and to include readings from both sides. This is an important, maybe indispensable, approach. Upper-division law students are already familiar with the adversarial structure and feel comfortable (perhaps too comfortable) with it. ${ }^{162}$

On the other hand, some topics are distorted and diminished when presented as either/or controversies, and some important kinds of learning and histening are eliminated in the adversarial inode. Care in presenting both sides is therefore only a partial answer.

If the class is not formally structured as a two-sided, equal-time exercise, and imstead storyreading, storytelling, and other methods are used, other problems inay arise. Every student of every background shonld be able to count on personal validation, space, and regard from the teacher in the classroom. Evidence strongly indicates that many inembers of racial minorities and women of all races frequently cannot count on such an atmosphere. ${ }^{163}$ However, efforts to alter the usual

Experience as Teacher: Discovering the Politics of Law Teaching, 33 U. ToRonTo L.J. 279 (1983) (searching exploration of efforts to alter power dynamics and the locus of initiative in a law school classroom).

162. Two-sided class formats that $I$ have tried with varying success include simulated congressional debates, see supra text accompanying note 114 , testimony at mock legislative hearings, presentations to a fictional school board, moot court arguments in fictional or real pending cases, informal debates between known or fictional personalities in a television talk show format, and a method known as structured controversy where teams are given a universe of materials on a structured issue, argue both sides to each other, and then drop role to join in hammering out "the best" resolution. For a discussion of the advantages of using structured controversy in the classroom, see David W. Johnson, Roger T. Johnson \& Karl A. Smith, Academic Conflict Among Students: Controversy and Learning, in THE Social Psychology of Education: CuRRENT ReSEARCH AND TheORY 199-231 (Robert S. Feldman ed. 1986).

163. See Taunya L. Banks, Gender Bias in the Classroom, 38 J. Legal Educ. 137 (1988) (misprints in text and footnotes corrected in Errata, 38 J. Legal Educ. No. 3 (1988)); Derrick A. Bell, Jr., Black Students in White Law Schools: The Ordeal and the Opportunity, 1970 U. TOL. L. REV. 539; Leslie G. Espinoza, Empowerment and Achievement in Minority Law Student Support Programs: Constructing Affirmative Action, 22 J.L. REFoRM 281 (1989); Donald K. Hill, Law School, Legal Education and the Black Law Student, 12 T. MARSHaLl L. REV. 457 (1987); Dawn Ross, Program Offers Minority Survival Kit, HARv. L. REc., Sept. 30, 1989, at 3; Dorene R. Sarnoski, The Law Review Selection Process: An Analysis of Its Disparate Impact on Minority Students, 7 LAW \& INEQUALITY 459 (1989); Teri Silvers, Students Tell Faculty About Silencing Concerns, HARVARd LAw Record, Spring 1989, at 391; Nerissa B. Skillman, Misperceptions Which Operate as Barriers to the Education of Minority Law Students, 20 U.S.F. L. REV. 553 (1986); Vicky Spelman, Combatting the Marginalization of Black Women in the Classroom, 10 WoMEN's STUD. Q. 15 (1982), reprinted in GeNDEREd SuBJECTS: The DyNAMICS of FEMINIST TEACHING 240 (Margo Culley \& Catherine Portuges eds. 1985); Gerald Torres, Teaching and Writing: Curriculum Reform as an Exercise in Critical Education, 10 Nova L.J. 867, 875 (1986); Stcphanie M. Wildınan, The Question of Silence: Techniques to Ensure Full Class Participation, 38 J. Legal Educ. 147 (1988); Katina Leodas, Women in Law Schools: The View From the Margins (unpublished paper on file with the author). I believe that the problems, analyses, and inethodologies conveyed by most of these sources describe a very different version of reality than that conveyed by the descriptions that typify recent attacks on multiculturalism. 
classroom climate may be perceived as departing from the presumptively neutral norm and therefore as biased. Members of traditionally more privileged groups may well feel themselves displaced by the entry of unfamiliar narratives and may experience unpleasant sensations of demotion or blame. The same questions of "objectivity" that can arise in how the teacher selects readings, or how she presents her own and others' views, can also arise in how she treats students.

I do not pretend to have learned to dance these knife-edges with the grace, wisdom, and fairness to which $I$ aspire. ${ }^{164} \mathrm{I}$ am certain, however, that they cannot be avoided through "neutrality" or "objectivity." Attempts to do so will only obscure the dilemma.

\section{On Doing the Right Thing}

In addition to the imdoctrination issue there are questions of teacher morale and commitment that may deter us from the race-conscious classroom. Even if we in legal education do succeed in reaching the consensus I mamtam is within our grasp, difficult teaching issues will remam. Those who take up this task will need to be patient, persistent, and brave in the face of some intractable but not impossible problems.

As I encouraged students, especially black students, to share with me and with others their experiences of life at a predominantly white law school, I began to read and hear story after story of hurt. Students reported imcidents in class, in the halls, on the lawn at graduation, in the dormitories, on the sidewalk, and in the stadium. These incidents ranged from aggressive racial epithets hurled in circumstances where the threat of physical violence was quite real to the wounds felt by a student when she perceived her professor to be consistently avoiding eye contact with the black students in his classroom.

164. I was, however, gratified to read the following anonymous student comment:

[A]fter having taken this class, my attitudes towards women's rights have quite changed. I am quite a conservative person and am not into "rights movements". But after having listened to the lectures and presentatious, and after reading the materials, I really do believe that women deserve a greater piece of the pie in our society. I, for some reason, never really thought of women the same as I would thimk of minorities, in that I never considered that women's rights have been deprived.

Something happened to me about a weck ago. I was in another class talking to a friend, a girl, who is also in our Discrimination class. I told her that I felt our Discrimination class was bemg taught in a biased manner. She asked me how so and I told her that in the context of women's rights, the class was taught almost exclusively from the viewpoint of a female. She said to me, "We as women, have lived with bias for hundreds of years; maybe it's time that you (men) felt it too." That statement really opened my eyes.

This student's new posture as listener should not become permanent, of course, and his woman friend's victim status should not become institutionalized into a right to monopolize all future conversations. But exchanging positions-altering who talks and who listens-is grand. And when those doing the exchanging come from positions of significant inequality to begin with, then the exchanging of positions, while it should be shared and mutual, can never be symmetrical. For a discussion of epistomological asymmetries of the center and the margin, see Harris, supra note 133. See also supra notes 140-48 and accompanying text (indoctrination discussion). 
Interestingly, my initial reaction to most of these stories was incredibly self-absorbed. At least with regard to stories about classroom interactions, my immediate response was to begin thinking about how I could avoid such behavior myself in the future. My reaction contained a distinct thread of self-protection.

So, for exainple, when I heard that one student was angry and resentful at being cast as "Mr. Equal Protection" in a constitutional law class at another institution, when I heard what pressure and hunniliation he felt at being repeatedly forced to perform as sole spokesperson for the black race, I resolved to avoid at all costs succuunbing to any knee-jerk inipulses to turn to a black student for racial perspective on soine problem a class was discussing.

But I soon ran into a problem. When I heard that another black student was deeply offended at not being called on more often, that she felt her professor assumed she was ill-prepared and incapable, that all the messages she received told her she had no value in the classrooin, and that she most especially resented it when the professor pointedly ignored her during a lengthy discussion of a racial question, I became anxious. How would I be able to figure out and then do the right thing? One student wanted more attention, the other less. One wanted to be a spokesperson for her race, the other did not.

If you are a teacher of students in a predominantly white but desegregating institution, you cannot consistently do the right thing no matter how hard you try, if by the right thing you mean behavior that inakes the average student of color feel equally as welcomed and personally validated as the average white student. Nor can you consistently do the right thing if by that you mean behavior that allows the average white student to avoid any feeling of being personally accused or defensive when matters of race are discussed. Nor can you consistently do the right thing if by that you mean behavior that results in the average student of any race feeling enthusiastic and competent when encountering ideas that force that student to examine his or her own privileges, shames, and resentinents.

Achieving such goals with any regularity is not an available option because the present realities of race in American higher education are coinprised of many different factors that are working against such goals. And inost of those factors are not within a teacher's control. "The right thing," if defined in this way, is a snare and a delusion. Neither teachers nor students are superheroes. And we have precious few role models for productively discussing inatters of race across racial lines.

Nevertheless, if you cannot always do the right thing, you can sometinies do $a$ right thing. Progress will not come from having discovered "the" right behavior for each situation and then donning it like moral 
armor. Instead, it will come by establishing a steady pattern of repeated effort and openness and by engaging in interactions that cumulatively lielp you begin to cure the ignorance that teacliers and students alike almost certainly bring to a race-conscious educational setting. ${ }^{165}$

As one benefit of this process, teacliers inay work themselves into a better position to discern racism and to support students of color in productively reacting to it. Second, teacliers may become better able to discern the needs and problems of all students whio are entitled to (tliat elusive concept) a fair sliare of professional time and attention. Third, teacliers may become better able to discern situations in whicli students of color are liaving problems that they inaccurately or disproportionately attribute to racism and then to support those students im productively liandling and reexamining those situations. The ability to do all of these things is important to tlie welfare of all students and to the future quality of racial integration in our institutions.

Sometimes, of course, teacliers will fail miserably because of their own limitations and tliose of their students as well. ${ }^{166}$ Despite the failures that will certainly occur, I suppose it is obvious by now that I behieve the undeniable difficulties, pains, and dangers of a class that consciously focuses on race are wortll enduring. ${ }^{167}$ Until we can begin to forge ways to talk deeply with each other about these inatters across

165. A particularly challenging and sophisticated take on the issue of race in the law school classroom was offered by Regina Austin at the plenary session of the American Association of Law Schools in January, 1990. Austin asked her audience to consider and put first the educational needs of students of color when matters of race are touched upon in the classroom. She noted with sharp irony and concern that a inore familiar pattern in too many well-intentioned discussions is the use of black students as providers of "curricular inaterial" for their white classmates.

In these instances, Austin says, the experiences and insights of black students function primarily as vehicles to aid the teacher in her primary goal of educating her white students. This endeavor inay or may not have salutary effects for white students but does precious hittle to challenge the understandings or advance the empowerment of black class members as law students, as intellectuals, or as future citizen-lawyers.

166. For ways of improving classroom environments for black students, see Association of AMERICAN COLleges Fund for the IMPROVEMENT of POST-SECONDARY Education, White FaCulty, Black Students: Exploring Assumptions aND Practices (1984) (whose title should not be taken to suggest that faculty members of color do not face many identical and similar problems).

167. After the class was over, one student offered the following observations:

In fiftecn short weeks, a group of law students learned that racism and sexism can be identified, analyzed and understood. Not powerful, elusive, imnate forces, they are learned and therefore can be remedied.

The remedial work meant that students were sometimes placed in awkward positions. We had to rehash a history that made us uncomfortable. We had to read cases and discriminatory laws inost despaired in reading. We had to respectfully listen to and consider comments made by classmates from various racial and economic backgrounds. We had to empathize. And ultinately, we came to respect and understand each other a bit more.

This fall 1989 class was particularly unique in that most of us were in our inid to late twenties and had come of age during our country's inost recent women's and minority movements. The busing and ERA issues were espeeially enlightening. Many classinates 
profound differences, despite the hurt involved, we cannot seriously hope to resolve the long-standing problems of race that continue to confront us as we proceed into our third century as a nation. Nor will we have opportunities to experience the delight that surely and unpredictably will grace us at times when counecting and commumicating are not as unattainable as we had feared. The rewards of the underground classroom can also be real.

\section{B. The Canon}

At the beginning of this Essay I said that those of us in legal education are in a special position witlı regard to the current debate raging over the canon and curriculum reform. It was iny thesis that at least with regard to race, legal educators sliould be able to acknowledge quite readily the central role played by race at numerous critical junctures in our constitutional history, and therefore sliould be able to agree that matters of race deserve central focus in the law scliool curriculum. I now wisli to revisit and reexamine that basic proposition. Clearly the reality of the matter is inore complex and problematic than tlie original thesis suggested, and any strongly exceptionalist argument for legal education would probably be naive.

In the first place, if agreenent on this core knowledge were all that easy and self-evident, then surely it already would be in place and functioning. Such is not the case. ${ }^{168}$ While I assume all law scliool curricula involve soine exposure to the postwar amendinents and Brown v. Board of Education, ${ }^{169}$ I have encountered third-year law students who were hazy on the roots of the fourteentli amendment and its relationship to slavery, emancipation, and Reconstruction. I have yet to ineet a black law student who seemed to feel that the achievements or contributions of

had attended schools where this had occurred and could offer insight. Several women had worked for ERA ratification and recalled their disappointment at its defeat.

Race is still such a dynamic topic in the Umited States, that courses such as this are essential. It was important to analyze civil rights acts from their inception until today.

During Christmas break, I received cards from class members. Many inscriptions noted the racially motivated killings of a white federal judge and a black attorney due to their work on discrimmation cases. The saga continues.

Discrimination and the Law should remain a part of the law school eurriculum. Future generations of lawyers will need this training.

168. Sanford Levinson remarked in a bicentennial talk that surely one of the most difficult problems presented those who would celebrate the Constitution [is] chattel slavery. An ever-present temptation revealed, among other places, in the contents of most casebooks on constitutional law is basically to ignore chattel slavery as a constitutionally legitimized presence in American history. To put it mildly, that does not seem to be a satisfactory solution, any morc than is the mindless celebration of Western humanism or Christian sensibility whieh ignores the Holocaust's arising in a land of unusually high culture and piety.

Sanford Levinson, Pledging Faith in the Civil Religion; Or, Would You Sign the Constitution?, 29

WM. \& MARY L. REV. 113, 129 (1987).

169. 347 U.S. 483 (1954). 
African-Americans to constitutional law were regularly and explicitly recognized during the course of his or her legal education. There are several factors that prevent legal educators from reaching an easy consensus about the centrality of race in constitutional history.

First, any decision to underscore race in the law scliool curriculum cannot coine easily in part because all matters of race are so divisive in American society. ${ }^{170}$ The inessages from the undergronnd classroom provide evidence of these divisions. Higher education, far from being above controversies over race, is deeply enmeshed in them. In fact, higlier education is sometimes at center stage. ${ }^{171}$ These differences and

170. For an eclectic assortment of materials on the current racial divide, see NATIONAL Research Council, A Common Destiny: Blacks and AMERICAN Society (Gerald D. Jaynes \& Robin M. Williams eds. 1989) (empirical evidence about the state of contemporary race relations and conditions of life for black Americans); Thomas B. Edsall \& Mary D. Edsall, Race, ATLANTIC MoNTHLY, May 1991, at 53 (debate over racial policy); Julian Bond, The Civil Rights Act: White Men's Hope, N.Y. Times, Jıme 24, 1990, $\S 4$, at 21, col. 2 (hilarious op-ed piece on preferential race treatment); Peter A. Brown, Issue of Racial Hiring Quotas Reaches Center Stage in Political Arena, Knoxville News-Sentinel, Jime 24, 1990, at A5, col. 1 (resentınent over racial hiring quotas and federal civil rights bill); The Assault on Equality: Race Rights and the New Orthodoxy, special issue of NATION, Dec. 9, 1991 (Adolpl1 Reed, Jr. \& Julian Bond eds.) (series of articles criticizing recent efforts, especially by Democrats, to move beyond race); Don Wycliff, Blacks Debate the Costs of Affirmative Action, N.Y. Times, June 10, 1990, $\$$, at 3, col. 1 (misgivings about affirmative action); Walter Sliapiro, Unfinished Business, TIME, Aug. 7, 1989, at 12 (discussing findings of National Researcl Council and arguing that racial issues contimue significantly to divide blacks and whites and have led to the deterioration of race relations).

171. The upsurge of racial and religious attacks on college campuses is probably the most visible inark of higher education's imvolvement. See Steve France, Hate Goes to College, A.B.A. J., July 1990, at 44; Courtney Leatherman, More Anti-Semitism Is Being Reported on Campuses, but Educators Disagree on How to Respond to It, Chron. Higlier Educ., Feb. 7, 1990, at A1, col. 3; Officials Step Up Efforts to Eradicate Racist Incidents on Campus, Black Issues in Higher Educ., Jan. 18, 1990, at 32, col. 1; Josepl Berger, Deep Racial Divisions Persist in New Generation at College, N.Y. Times, May 22, 1989, at A1, col. 1. But problems short of pliysical violence also persist and may be increasing. See Carolyn J. Mooney, Stanford Panel Reports Strained Campus Race Relations; U. of Michigan Faculty Rejects Required Course on Racism, Chron. Higher Educ., Apr. 12, 1989, at A15, col. 2 (noting tliat at Stanford many minority students feel subtle but pervasive forms of prejudice). Strong controversy attends efforts of universities to stein or blimt this upsurge, especially when such efforts involve regulation of speecl. The hate-speecli controversy is beyond the scope of this paper but clearly involves many of the issues I try to deal witl liere.

In addition, differences over affirmative action in admissions and hiring are rampant in undergraduate and graduate programs as well. See, e.g., Robin Wilson, Article Critical of Black Students' Qualifications Roils Georgetown U. Law Center, Chron. Higlier Educ., Apr. 24, 1991 at A33, col. 2 (discussing angry reaction of some administrators and students to essay allegiug that black students admitted to the law scliool were less qualified than white students); Dinesh D'Souza, Sins of Admission: Affirmative Action on Campus, NEw RePUBlic, Feb. 18, 1991, at 30 (examining and criticizing universities' affirmative action); A Class Sends Message to Harvard Law School, N.Y. Times, Nov. 21, 1990, at B11, col. 3 (reporting on student-imitiated lawsuit over faculty diversity); Steplien L. Carter, The Best Black and Other Tales, Reconstruction, Winter 1990, at 6 (black law professor from Yale criticizing affirmative action at the undergraduate and graduate levels); Fox Butterfield, Old Rights Campaigner Leads a Harvard Battle, N.Y. Tinies, May 21, 1990, at A18, col. 1 (reporting black professor's protest over Harvard's failure to hire black woman law professor); Lisa G. Markoff, Berkeley Pressure Group's Stand Draws Some Anger, Some Praise, Nat'1 L.J., Apr. 9, 1990, at 4 (reporting on student protests over lack of diversity in faculty hiring); Slielby Steele, The 
tensions will necessarily affect discussions about race in the law school curriculum. Participants in such discussions cannot and should not converse in a vacuum, but the alternative to a vacuum may well be a highly charged atmosphere that makes many of us uncomfortable both in discussions among faculty and in discussions in classrooms. ${ }^{172}$

There is a second reason why it will be difficult to embrace a raceconscious curriculum in legal education. The foregoing suggests that while the centrality of race to American legal history may be undeniable, the interpretation of that fact is likely to prove a matter of serious disagreement, ${ }^{173}$ just as matters of interpretation divide adversaries about the canon in other disciplines. ${ }^{174}$

For example, those offended by Marshall's critique of the 1787 Con-

Recoloring of Campus Life, HARPER's, Feb. 1989, at 47 (a black English professor criticizing the tone of contemporary racial imteractions and affirmative action); Michael A. Olivas, Latino Faculty at the Border: Increasing Numbers Key to More Hispanic Access, CHANGE, May/June 1988, at 6 (arguimg for more affirmative action in relation to Latino law professors); Jeri Spann, Achieving Faculty Diversity: A Sourcebook of Ideas and Success Stories (1988) (brochure available from the University of Wisconsin System, Office of Equal Opportunity Programs and Policy Studies) (observing in the preface that "[a]chieving diversity in higher education is an imperative that will directly affect our future economic well-being, our capacity to educate and govern in a truly democratic way and to create a cultural pluralism that celebrates difference," id. at vii).

172. I sympathize with this discomfort. As the earlier discussion of my classes should make clear, my own reactions and on-the-spot decisions im a class where I was consciously trying to tackle the race issue were often driven by a need to diminish my own tension level.

However, I am convinced that more serions dangers attend silence and avoidance. These dangers were made apparent in my own hometown when a local principal decided that a scheduled television newscast on the history of race relations in America was too inflammatory to be shown to high school students. See Jesse Bond, Doyle High Exercises 'Right,' Blacks Out Channel One Segment, Knoxville J., May 19, 1990, at 4A, col. 1 (school officials were particularly concerned about segment containing a historical overview of racism in America); Roger Harris, Doyle High Refuses to Air Segment of Channel One: Report on Prejudice Judged Inflammatory, Knoxville NewsSentinel, May 18, 1990, at A1, col. 1 (the principal observed: " 'I didn't see it myself, but [my committeel told me they just felt it was something we shouldn't watch. . . . They said it was too much on prejudice and would stir up some people" "). Meanwhile, a white supremacist bookstore, with a special outreach program for youth, was opeming across town. See David Keim, Far-Right Political Group to Open Knox Bookstore, Knoxville News-Sentimel, June 18, 1990, at A3, col. 1. It appears that young people in the 1990s in Knoxville and elsewhere will be having plenty of discussions about race. The question is whether those responsible for their education will be participating in those conversations. Official silence will not make racial tensions go away.

173. Robert Burt, for example, while treating Dred Scott v. Sandford, 60 U.S. (19 How.) 393 (1857), as central, argued that it should be read as a story about judicial activism, not primarily as a story about race. Robert A. Burt, What Was Wrong With Dred Scott, What's Right About Brown, 42 WASH. \& LeE L. REV. 1 (1985).

174. The echoes across disciphines are startling at times. For a hint of the scene in the fine arts, see Michael Brenson, Is 'Quality' An Idea Whose Time Has Gone?, N.Y. Times, July 22, 1990, § 2 (Arts \& Leisure), at 1, col. 1 (discussing debate over the quality issue, which includes questions about the virtues of "form versus content, Western values versus non-Western values, men versus women"). For a glimpse at a related historiographic debate, see Mark Tushnet, Constitutional Law and Himmelfarb on Social History (Book Review), 82 Nw. U.L. REV. 864 (1988) (examining controversy over "new social history," which focuses on social forces). 
stitution ${ }^{175}$ argue that he took too narrow a view, fixating on the document's flaws and failing to deal appropriately with its strengths and enduring achievements. William Bradford Reynolds, for example, coinplained that "Justice Marshall's . . . thesis is gerry-built on a regrettable overstatement of perceived flaws in the Constitution without so much as a passing reference to the qualities that have endured for the past two hundred years." 176

This criticism echoes those voices in the larger canon debate that complam about a reductionist attitude that criticizes but never celebrates the western tradition. One such voice belongs to Lynne Cheney:

[A] crucial consideration is how great books are taught. Do we hold up Milton simply to display his sexism, as the A.C.L.S. essay does, or do we also help students to see the powerful and enduring questions he raises about pride and sin and salvation? Do we study the great books of the past solely in terms of errors perceived in the present, or do we also seek to understand why successive generations have formd these books speaking to them anew? ${ }^{177}$

I simply do not hear the voices advocating multiculturalism as carping or reductionist in the way both Reynolds and Cheney seemed to suggest. When Thurgood Marshall and similar newcomers speak, I hear them in many imstances sharing new stories and criticizing familiar ones in ways that open avenues of debate, celebrate commonalities among humans, and enrich our understanding of where we have been and where we might be headed. Clearly some in the legal acadeiny will disagree with me, however. Some are willing to concede that race played a central role at some points in our constitutional history but conclude that we

175. See supra text accompanying notes $65-75$.

176. Reynolds, supra note 74 , at 1350 . One student in my class made a similar criticism of my own approach:

As I sat in class during the discussions on race and slavery, one underlying aspect kept plaguing iny thought-NEGATIVISM. I became so frustrated in hearing only negative sides of the racial issues. ...

I am not proposing that we look only to the positive aspects because it is true that we learn from our mistakes. [ $] \mathrm{t}$ is clear the mistakes this country has inade in the realm of racial issues, but the country has made tremendous progress. This progress shonld be as important as the barriers and obstacles which stood in its way.

177. Cheney, supra note 4, at A40, col. 1 (criticizing essay ealling for inore inclusive core curriculum). Ms. Cheney, current chair of the National Endowment for the Humanities, is a highprofile player in the canon controversy and is inarried to the current Secretary of Defeuse, a "spousal fact" that in this context I believe is pertinent.

In parallel fashion the editors of The New Republic announced: "We are opposed to the current 'multiculturalist' trend, then, not because we believe that accounting for sexual, racial, and politieal bias in texts is not a worthwhile (though limited) intellectual exercise, but because we believe that it is not the only worthwhile intellectual exercise." The Derisory Tower, New Republic, Feb. 18, 1991, at 5, 6 [hereinafter The Derisory Tower] (emphasis in original). The unasserted assertion here, of course, is that inulticnlturalists believe that accounting for bias in texts is the only worthwhile intellectual exercise. The assertion is not supportable. 
have moved beyond racial roots to color-blind umiversals and properly so.

If our notions of equality, liberty, due process, and federalism were all forged in important ways in the leat of struggles over slavery, what we make of that legacy and heritage is still open to contest. The continued instability, even incolierence, of affirmative action doctrine is only one indication of low unsettled is national legal opimion about this central issue of race and the Constitution. ${ }^{178}$ Shonld we interpret our core constitutional values concerning race as centering on and deriving their deepest imspiration from a historical, contextual rejection of actual and deeply rooted white supremacy, or as creating a color-blind affirnation of timeless, umiversal human equality, or as some dialectical relation between these two visions? This is not an easy question.

A third reason why race in legal education's core curriculum may not be a subject of easy consensus is rooted in patterns of institutional inertia and concerns about teacher autonomy. It is costly for teachers to cliange the ways they teach; time spent developing new materials and approaches is time not spent on all the other things that professors do. These are not trivial obstacles. Institutional recognition of the costs of curricular change to individual faculty members and the developinent of ways to avoid penalizing those who undertake curriculum integration projects are key to a fair and effective effort. ${ }^{179}$

178. Compare City of Richmond v. J.A. Croson Co., 488 U.S. 469 (1989) (applying strict scrutiny and holding that city's set-aside program for minority businesses was unconstitutional) with Metro Broadcasting, Inc. v. FCC, 110 S. Ct. 2997 (1990) (upholding a congressional scheme awarding preferences to minority-owned applicants for broadcast licenses).

179. Costs of any action are, of course, relative to the benefits of the action and to the costs of inaction. A theme of those pressing for greater hiring and curricular diversity is the need to prepare for an increasingly multiracial society. See WILlIAM B. JohNSTON \& ARNOLD E. PACKER, WORKFORCE 2000: WORK AND WORKERS FOR THE TWENTY-FIRST CENTURY 75-76, 105 (1987). Johnston and Packer predicted that by the year 2000 the growth rate of the workforce will slow, its age will rise, the participation of women and ininorities will imcrease, and immigrants will represent the largest slare of workforce growth since World War I, see id. at 75-76, and urged the integration of black and hispanic workers into the economy, see id. at 105. These commentators emplasized the drastic costs of inaction. See also Peggy Schmidt, Women and Minorities: Is Industry Ready?, N.Y. Times, $\S 3$ (Magazine), Oct. 16,1988, at 25, col. 2 (reporting that industries will face a competitive disadvantage if they fail to provide eareer-development services for minorities and women).

This news is in some ways lieartening for those interested in the welfare of people of color. If those with power and influence believe it to be in their own interest for nonwlite youth to get useful scliooling, perhaps useful schooling will become more available to nonwhite youtl. As students of Derrick Bell's interest-convergence liypothesis will recognize, however, there is an inherent weakness in any strategy built on this foundation. Reforms won by virtue of soineone else's selfinterest liave a way of evaporating as times cliange. See Derrick Bell, Brown and the InterestConvergence Dilemma, in Shades of BROWN: New Perspectives on SCHOOL Desegregation 91 (Derrick Bell ed. 1980) (arguing that sclıool desegregation lias failed and suggesting that inost meaningful remedies have ouly been imposed when they converged with tlie interests of whites). But if these demographic changes are accompanied by incrcased organizing witlin the nonwlite commmunity, they could lead to change in power. Numbers alone, of course, inake little difference, as any resident of the black belt or South Africa could tell you. 
In some instances the costs of curriculum integration have been properly recognized. For example, the Higher Education Extension Service, im a review of reports on multiculturalism issued by twelve different colleges and universities, noted:

At many institutions [a] strategy is to give faculty time and support to make their existing courses less Eurocentric. Though harder to institute [than faculty seminars or separate course requirements] becanse of faculty reluctance, this is obviously a preferred solution, since it both makes the college curriculum genuinely pluralist, rather than merely "inulticultural" at the margins, at the same time as it prevents the resegregation of minority students into ethnic studies-related courses. ${ }^{180}$

In addition to problems of mertia and the costs of innovation, issues of teacher autonomy pose problems. Professors are rightly jealous of their freedom to teach what and how they think best and may perceive efforts at curriculuin expansion as the imposition of a different but equally oppressive brand of inonoculture on the educational project. This perspective has been taken up by the defenders of the canon in the larger umversity context to oppose the introduction of new required elements to the core curriculum. Alan Kors, at a conference on the restoration of American education, reportedly warned that " "[u]nder the guise of liberation, people are trading one set of masters for another." "181 Kors agreed that political differences and competing cultural theories should be integrated into classroom discussions but he was also highly critical of a "radical fringe" that in his opimion dominates noncurricular programs. In his view, members of this fringe

establish an official history of America, an official agenda of moral priorities, an official view of race, gender, and class, and-most patronizing and evil of all-an official set of voices for what are, in fact, the wondrously diversified and individuated communities of America's African Americans, woinen, and gays. ${ }^{182}$

180. Ensuring a Rainbow, supra note 37, at 7. These remarks suggest another, related controversy. Some critics of the traditional canon have parted ways over the relative merits of separate programs (for example, in women's studies or African-American studies) and curriculum integration. Issues of ghettoization, dilution, and resource allocation abound. These debates are important and have obvious implications for curriculum reform but they are beyond the scope of this paper.

181. Heller, Press for Campus Diversity, supra note 3, at 22.

182. Id. Criticism of new canon formation comes from the left as well. A recent development is the spectacle of "new canonizers" trying to cut a path between defenders of the old order who believe previously excluded candidates for adinission to the core are unworthy of inclusion and advocates of a new day who are wary of the ossifying and himiting results of attempts to define any new core, with the unavoidable implied complement of a new margin. Two feminist anthologizers, for example, complained of being caught between "influential conservatives [who] cannot imagine that the texts we have chosen might be either strong or representative" and "[s]ome feminists [who] argue that any act of canon-formation is a regressive one, while others judge our inclusions and exclusions on grounds of political "correctness.'" Sandra M. Gilbert \& Susan Gubar, $A$ New Anthology of Literature by Women: Does it Define a Canon or Merely 'Baptize a Kangaroo?', Chron. 
These observations in some ways parallel ideas advanced by Randall Kennedy, a black professor at Harvard Law School, who recently criticized three scholars of color working in the evolving area of critical race theory. He described thein as representing a dangerous trend in minority legal scholarship. ${ }^{183}$ Like Kors, Kennedy deplored what he saw as a new orthodoxy, a perceived insistence by these scholars that there is a inonohithic black or of-color experience that should be voiced and included both in the American law school curriculuin and in American society. ${ }^{184}$ Like Kors, Kennedy implicitly counterposed to this allegedly hoinogenized and essentialist vision an individualist pluralisin that he feared will

Higher Educ., Nov. 22, 1989, at B3, col. 3 (emphasis in original). Similarly, Henry Louis Gates, Jr., editor of The Norton Anthology of Afro-American Literature, which was published in 1990, observed:

The editing of this anthology has been a great dream of mine for a long time, and it represents, in the most concrete way, the project of black canon formation. But my pursuit of this project has required me to negotiate a position between those on the cultural right who claim that black literature can have no canon, no masterpieces, and those on the cultural left who wonder why anyone wants to establish the existence of a canon, any canon, in the first place.

Gates, supra note 156 , at 44 , col. 3.

183. See Randall L. Kennedy, Racial Critiques of Legal Academia, 102 HARv. L. REv. 1745 (1989) (critiquing work by Derrick Bell, see supra note 22, Ricliard Delgado, see supra note 37, and Mari Matsuda, see supra note 15).

184. Id. at 1787. Those who are alarmed by multiculturalisin in the larger university lave noted Kennedy's entry into this debate. He is cited with approval by Linda Chavez, Ronald Reagan's Director of the U.S. Commission on Civil Rights, as one of a group of "black intellectuals [who] have criticized at least some forms of racial preference." Linda Chavez, The Real Aim of the Promoters of Cultural Diversity Is to Exclude Certain People and to Foreclose Debate, Cliron. Higher Educ., July 18, 1990, at B2, col. 3. Cliavez's list also mcluded Slielby Steele, Thomas Sowell, Glenn Loury, Walter Williams, Julius Lester, and Steplien Carter, a law professor at Yale, whose 1991 bestselling book, REFLECTIONS OF AN AFFIRMATIVE ACTION BABY, has since been released. Id.; see also Denise K. Magner, Black Intellectuals Broaden Debate on Effects of Affirmative Action, Chron. Higher Educ., Oct. 16, 1991, at A17, col. 4 (describing a new group of "[b]lack scliolars who criticize or oppose racial preferences" and who "are profoundly influencing the national debate"). Chavez did not at that tinie mention Clarence Thonias, but in light of later developments his would obviously be an important name to add to this list. Interestimgly, Chavez also failed to mention Kennedy's article defending affirmative action, Persuasion and Distrust: $A$ Comment on the Affirmative Action Debate, 99 HARv. L. REV. 1327 (1986).

This conversation promises to continue. See Stephen L. Carter, Loving the Messenger (Book Review), 1 YALE J.L. \& HuM. 317 (1989) (favorably reviewing Juhius Lester's 1988 book, Lovesong: Becoming a Jew, which criticized black leaders for appropriating suffering as something unique to blacks). For direct and indirect commentary on Randall Kennedy's views of the new critical race theory, sec Milner S. Ball, The Legal Academy and Minority Scholars, 103 HARV. L. REV. 1855 (1990); Barnes, supra note 8; Scott Brewer, Colloquy: Introduction: Choosing Sides in the Racial Critiques Debate, 103 HARv. L. REv. 1844 (1990); Carter, supra note †; Richard Delgado, Mindset and Metaphor, 103 HARV. L. REV. 1872 (1990); Delgado, supra note 8; Leslie G. Espinoza, Masks and Other Disguises: Exposing Legal Academia, 103 HARv. L. REv. 1878 (1990); Johnson, supra note 8; Kennedy, supra note 8. For news coverage, see Charles Rotlifeld, Minority Critic Stirs Debate on Minority Writing, N.Y. Times (Law), Jan. 5, 1990, at B6, col. 3; Jon Weiner, Law Profs Fight the Power, Nation, Sept. 4, 1989, at 246. Perhaps the rich veins of race-related history and doctrine that Randall Kennedy contimues to explore are proof that my optimistic thesis is true: we in legal academia should be able to reach consensus about the centrality of race despite vigorous disagreements about its mcaning. 
be smothered if the new race theorists prevail. ${ }^{185}$

In my own view, Kors was wrong to say these new voices are significantly silencing others and Kennedy was wrong in his charge of essentialism. Likewise, the argument I make here does not envision the enthroning of a new orthodoxy. It does not require problematic inroads on teacher autonomy. I simply argue that we should agree that our constitutional heritage is one that turns profoundly on race. We should read about this, think about it, and talk about it. Individual teachers should, with enthusiastic support from their institutions, experiment with teachmg about race in the American legal system and should share their experiences with others. Individual law schools should discuss the centrality of race as they discuss the centrality of other curricular values. When this discussion occurs, it seems inevitable that curricular and pedagogical consequences will follow and that they will be diverse.

\section{Conclusion}

My colleagues in legal education may decide that the hyperbole of the canon debates and the controversies over inulticulturalism are filled inore with heat than light and have hittle to offer law schools. Indeed, there is a tempest-m-a-teapot quality to some of the larger canon conversation. As I read the recent round of attacks on multiculturalism, I found myself recalling Mark Tushnet's quip about a traditionalist history professor's diatribe against the new social history: "[Her] essays are filled with apocalyptic imagery, which leads a reader not engaged as [slie] is im intradisciplinary polemics to want to say, 'Lighten up." "186

Nor is the disease of hyperbole confined to one side of the debate. Henry Louis Gates, Jr., remarked at a recent American Studies Association meeting that the inulticulturahists themselves suffer at times from "a windily apocalyptic rletoric that had nowlere to go when its putative demands were granted." 187

Meanwhile, observers on both sides liave pointed to the irony that while the academic debate rages, the social problems and power relations of the real world contmue apace. Sometimes those involved in the fray can lose sight of the reality for the pleasures of the debate. Occasionally they may conflate the two. Gates wryly observed about his fellow curriculum expanders:

[O]ur rhetoric sometimes depicts the high canonical as the reading matter of the power ehte. You have to imagine James Baker curling up with

185. See Kennedy, supra note 183, at 1782.

186. Tushnet, supra note 174, at 864 .

187. Karen J. Winkler, Proponents of 'Multiculturalist' Humanities Research Call for a Critical Look at Its Achievements, Chron. Higher Educ., Nov. 28, 1990, at A8, col. 5. 
the Pisan Cantos, Dan Quayle leafing through The Princess Casamassima. ...

... The recent turn toward politics and history in hiterary studies has turned the analysis of texts into a marionette theater of the political, to whiclı we bring all the passions of our real-world commitınents. . . . We pay hounage to the marginalized and demonized, and it feels almost as if we've righted an actual injustice. . . .

... Yet it sometimes seeins that blacks are doing better in the college curriculum than they are in the streets or even on the campuses. . . .

... [W]e should be clear about when we've swatted a fly and when we've toppled a giant. ${ }^{188}$

In supporting the canon defenders, editors of The New Republic likewise noted that " $[t]$ he furor over affirmative action in admissions and hiring in our universities and over a 'multicultural' curriculuin is, in fact, a bitterly ironic distraction from the battle against racial injustice in our society at large."189

Both of these observations carry weight and give me soine pause in my own time-consuming pursuit of these matters. Nevertheless, estabhishing places nit the university where the history and dynamics of racial subordination are studied, and establishing places in the university where African-American nitellectuals can be nourished and enipowered, are not "distraction[s] from the battle against racial injustice" but indispensable necessities for its successful outcome. African-American coinmunities, like other subordinated cominunities, need intellectuals who feel tied to and partisan about thein, who can bring the wisdom and experience of those cominunities into the acaderny and enlist the resources of the acadeniy to work on the probleins of those coininunities. ${ }^{190}$

There are differences between the critics and defenders that reflect more than hyperbohe jousting and miscommunication. Whether the present tendency toward polarization offers the healthiest clinate for discovering and fighting over the best definitions of these differences is an open question. Certainly the false polarities are maddening. The real dichotomies are, I beheve, still coming to hight, and the recent attacks on multiculturalisin, despite their tendency to exaggerate, even their occasional viciousness, may end up playing an inportant part in helping them to enierge.

First, these attacks have underscored some real questions about the results of multiculturahist practice, real dangers and dilemınas facing

188. Gates, supra note 156 , at 44 , col. 2 .

189. The Derisory Tower, supra note 177, at 6.

190. See Kennedy, supra note 8 , at 707 , passim. It almost goes without saying that not all African-American scholars will choose to play this role. But it is vitally important that some of them can and do. 
educational institutions that are attempting to invent ways for their faculty and students to talk and grow across difference in a society still characterized by profound inequities in power and resources. ${ }^{191}$ These issues are already the subject of debate and discussion within the inulticulturalist camp. Cornel West, a black leftist theologian, observed at a recent American Studies Association meeting that research on race, class, and gender had led to " 'vast balkanization and fragmentation'" and called for scholars " to go beyond the academic politics of difference to look at these [societal] issues." "192

One aceusation of those opposed to multicultural education is that emphasizing difference leads to despair and cynicisin about "different" individuals ever communicating with each other. ${ }^{193}$ These and related concerns are powerful and real. However, to speak as though advocates of multiculturalism are indifferent to the difficulties of simultaneously affirming difference and finding commonahties is just plain wrong. ${ }^{194}$

191. The racial hierarchy in society makes racial difference in the classroom, dormitory, or fraternity honse a loaded, contested, and tense difference, which no amount of universalist sentiment can dispel. We cannot turn that difference into a candy-coated UNICEF world any more than we can remove it from history. On the other hand, there are many ways that people deal with charged and tense differences, and methodologies surely have some effect. We need to be exploring what such methodologies imight be, comparing notes on how we are doing, and leaming from our mistakes. See Spelman, supra note 163 (women's studies professor discussing problems with class discussions and considering how to improve classroom dialogue); Tamar Jacoby, Psyched Out, New REPUBLIC, Feb. 18, 1991, at 28 (describing the cynicism of both black and white students in a seminar on the history of race relations); Jacob Weisberg, Thin Skins, New REPUBLIC, Feb. 18, 1991, at 22 (describing the divisions among students at a small hberal arts college); see also Amid the Diversity, Racial Isolation Remains at Berkeley, Chron. Higher Educ., Nov. 14, 1990, at A37, col. 2 (discussing students' teudency to segregate themselves into racial and ethnic enclaves).

At any rate, it seems implausible in the extreme to attribute racial/cultural tensions or distances primarily to the marching advance of multiculturalism. Such an analysis would write off too much of what we know about the past and present both inside and outside of the academy.

192. Winkler, supra note 187 , at A9, col. 1.

193. See The Derisory Tower, supra note 177, at 6 ("The real danger is that the 'multicultural' orthodoxy is itself a disguise for an indifference.... It whispers in our ears that the barriers of race are unbridgeable; that thought cannot undo them; that education cannot mitigate them .....").

194. Patricia Hill Collins (a leading propouent of multiculturalism), for example, raised these issues in a 1989 speech:

In extreme cases, members of privileged groups can erase the very presence of the less privileged. When I first moved to Cincinnati, iny family and I went on a picnic at a local park. Picnicking next to us was a family of White Appalachians. When I went to push my daughter on the swings, several of the children came over. They had missing, yellowed and broken teeth, they wore old clothing-their poverty was evident. I was shocked. Growing up in a large eastern city, I had never seen such awful poverty among Whites. The segregated ueighborhoods in which I grew up made White poverty all but iuvisible. More importantly, the privileges attached to my newly acquired social class position allowed me to ignore and minimize the poverty among Whites that I did encounter. My reactions to those children made me realize how confining phrases such as "Well, at least they're not Black," had become for me. In learning to grant human subjectivity to the Black victims of poverty, I had simultaneously learned to demean White victims of poverty. By applying categories of race to the objective conditions confrontiug me, I was quantifying and rankiug oppressions and missing the very real sufferiug which, in fact, is the real issue.

Collins, supra note 143, at 16-17. 
Further, the dangers of recognizing and exploring difference, though real and thorny enough, are not in theinselves any justification for continuing to suppress difference and to silence voices from the margin. In any case, the questions reinain unsettled, and sharp criticism froin traditionalists could help move thein forward if those of us in the multiculturalist camp can be humble, savvy, and tough enough to draw out the lessons.

Both students and faculty im the legal acadeiny will approach these matters in many different ways. In talking with some of my colleagues who do not count themselves as partisans in these debates, it has struck me recently that our disagreements probably rest less on what texts we wish to include on our reading hists, or even on our vision of the university, than on our understanding of the larger society in which we live.

Our society and our culture have both strengths and weaknesses that arise from historical moments of great pride and great shaine. I recognize and give weight to both. Nevertheless, when I look at regional, national, and global conditions, I see imjustice and destruction looning very large. Further, these probleins appear to me to be in important part unnecessary. My view of the world - the fact that I see substantial injustice and beheve that the structures of that injustice are susceptible to change-profoundly influences my outlook toward many issues in the university. I know that for some the mequities and imjustices simply do not appear as pressing. Others may see that serious problems abound but lack confidence im the efficacy of any imaginable solutions. For still others the call for any but the most marginal of reforins, well-intentioned though it nay be, threatens a shde mto totalitarianisin. It is important to remember that these differences over the justice or injustice of present arrangements and over the possibility of meaningful change will affect the way inany of us assess the canon wars. ${ }^{195}$

Perhaps we can soon start to probe more meaningful differences than the false dichotomies that have played such a role in canon polemics. For exainple, when the National Association of Scholars says that affirmative action hiring is bad because it "encourag[es] the belief that it is the assertion of group power instead of the pursuit of individual achievement that reaps the most abundant rewards," 196 I think they inay

195. Perhaps what I am getting at about our different visions is something like the "overall perspectives" and "world-views" Howard Lesnick has so fascinatingly discussed. See Howard Lesnick, The Wellsprings of Legal Responses to Inequality: A Perspective on Perspectives, 1991 DuKE L.J. 413. Lesnick defined world-view as " 'a set of ordering perceptions, priorities, and premises' that shapes one's answers to specific questions." Id. at 413 n.3 (quoting Howard Lesnick, The Consciousness of Work and the Values of American Labor Law, 32 BUFFalo L. REv. 833, 842 (1984)).

196. The Wrong Way to Reduce Campus Tensions: A Statement by the National Association of Scholars, NEW RePUbL1C, Feb. 18, 1991, at 31 (advertisement). 
have discovered a real dichotomy, a contradiction worth exploring and fighting about.

What I have tried to suggest in this Essay is the idea that even across a fairly wide range of perspectives, we in legal education should be able to agree that, in American law schools and in American legal doctrine, race is a central matter. It is at the core of our received tradition. Its themes and deinands trouble the extracurricular life of our institutions; its questions challenge our society's future. We should recognize these realities and devote to them the conscious attention, both inside and outside our curriculum, that they so strongly demand of us. 
